INTER NATIONAL MONETARY FUND
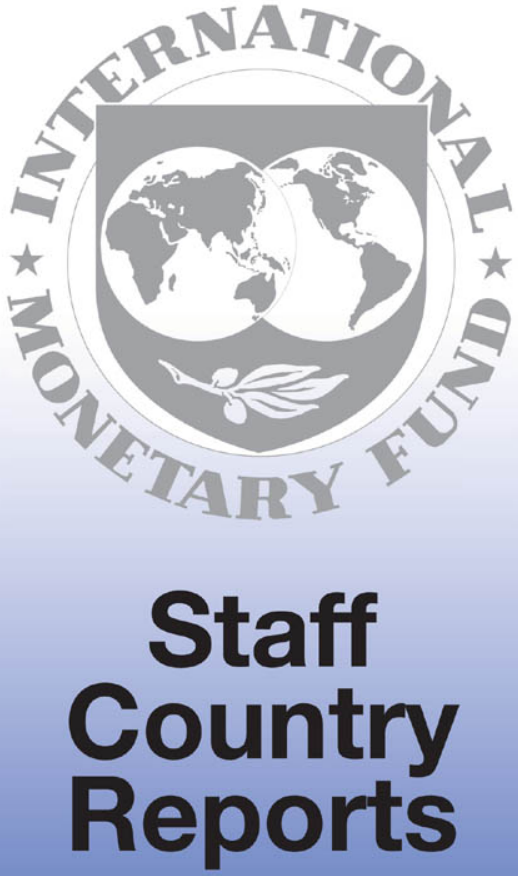
(C1999 International Monetary Fund

March 1999

IMF Staff Country Report No. 99/14

\section{Canada: Selected Issues}

This Selected Issues report on Canada was prepared by a staff team of the International Monetary Fund as background documentation for the periodic consultation with this member country. As such, the views expressed in this document are those of the staff team and do not necessarily reflect the views of the Government of Canada or the Executive Board of the IMF.

Copies of this report are available to the public from

International Monetary Fund • Publication Services

700 19th Street, N.W. - Washington, D.C. 20431

Telephone: (202) 623-7430 - Telefax: (202) 623-7201

Telex (RCA): 248331 IMF UR

E-mail: publications@imf.org

Internet: http://www.imf.org

Price: $\$ 15.00$ a copy

\section{International Monetary Fund \\ Washington, D.C.}




\section{INTERNATIONAL MONETARY FUND}

\section{CANADA}

\section{Selected Issues}

Prepared by S. Dunaway, M. Cerisola, P. De Masi, B. González-Hermosillo, A. Keenan, M. Leidy, G. Ramirez, S. Tokarick (all WHD), and P. Swagel (RES)

Approved by the Western Hemisphere Department

$$
\text { January 7, } 1999
$$

Contents

I. The Behavior of the Canadian Dollar

A. Factors Influencing the Real Exchange Rate $\ldots \ldots \ldots \ldots \ldots \ldots \ldots \ldots$

B. Modeling the Real Bilateral Exchange Rate $\ldots \ldots \ldots \ldots \ldots \ldots \ldots \ldots$

C. An Alternative Approach to Modeling the Real Exchange Rate .........

II. Inflation and the Natural Rate of Unemployment in Canada . . . . . . . . . 18

III. Business Taxation in Canada: An Update . . . . . . . . . . . . . . . . . 24 24

A. Business Taxation in Canada $\ldots \ldots \ldots \ldots \ldots \ldots \ldots \ldots \ldots \ldots \ldots \ldots \ldots \ldots 24$

B. April 1998 Report of the Technical Committee on Business Taxation . . . . 26

IV. The Canadian Personal Income Tax System . . . . . . . . . . . . 30

V. "Brian Drain" from Canada to the United States ................... 35

A. Data on the Size of Canadian Migration to the United States ......... 35

B. Incentives for Canadian Emigration to the United States $\ldots \ldots \ldots \ldots \ldots 37$

VI. Poverty Traps and Social Assistance Reform in Canada . . . . . . . . . . . . 50

A. National and Provincial Developments in Income Support Statistics . . . . .50

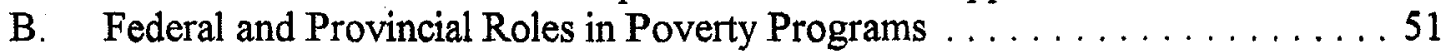

C. Incentive Effects of Income Support Programs $\ldots \ldots \ldots \ldots \ldots \ldots \ldots 52$

D. Recent Developments in Provincial Social Assistance Programs . . . . . . . 53

E. Considerations in Structuring Further Reforms $\ldots \ldots \ldots \ldots \ldots \ldots 5$

VII. Canada's Financial System ......................... 73

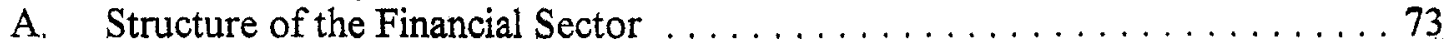

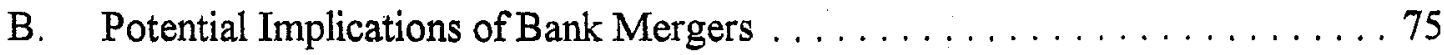

C. Task Force on the Future of the Canadian Financial Services Sector $\ldots \ldots 78$

VIII. Official Development Assistance 
V. 1. Professional Emigrants From Canada to the United States . . . . . . . . . 48

2. Managerial Emigrants From Canada to the United States $\ldots \ldots \ldots \ldots \ldots 49$

VI. 1. Share of Population on Social Assistance, by Province, $1980-97 \ldots \ldots .669$

2. Real Per Capita Expenditures on Social Assistance, by Province, 1980-97 . . 70

3. Real Per Capita Social Assistance Benefits and Real Per Capita

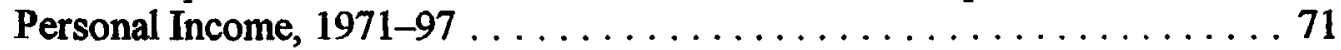

4. Real Social Assistance Benefits Per Recipient, 1971-97 . . . . . . . . 72

VII. 1. Banking Concentration Ratios Relative to Total Banking System Assets, $1997 \ldots \ldots \ldots \ldots \ldots$. . . . . . . . . . . . . . . . . . . 87

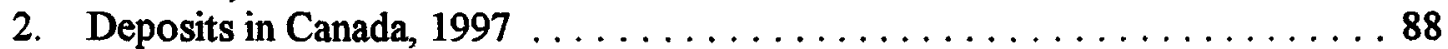

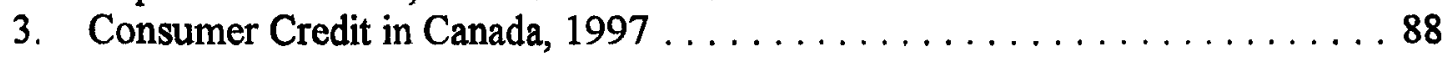

4. Residential Mortgage Credit in Canada, $1997 \ldots \ldots \ldots \ldots \ldots \ldots . \ldots 89$

5. Financing of Small and Medium Size Corporations in Canada, $1997 \ldots \ldots .89$

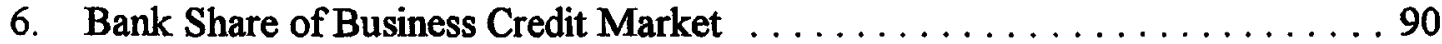

$7 . \quad$ Interest Rate Spreads of Six Largest Banks . . . . . . . . . . . . 90 


\section{THE BEHAVIOR OF THE CANADIAN DOLLAR ${ }^{1}$}

1. Over much of the past year, the Canadian dollar experienced periodic bouts of heavy selling pressure, and in late August the currency reached an all-time low value against the U.S. dollar. While the decline in the value and the increase in the volatility of the Canadian dollar have been largely attributed to the sharp deterioration in Canada's terms of trade in the wake of the Asian crisis, from a longer perspective, the recent decline has been part of a downward trend in the currency's value that has occurred since early 1991 (Figure 1). Notwithstanding this trend, the precipitous fall in the Canadian dollar during 1998 has raised some concerns and renewed the debate over the main underlying forces driving the exchange rate.

2. This paper reviews empirical evidence on the main determinants of the real bilateral exchange rate between the Canadian and U.S. dollars, with particular emphasis on the role played by cyclical and longer-term economic factors. The paper also aims to identify the nature of the shocks that have contributed to the recent downward trend in the Canadian dollar. The analysis shows that fluctuations in the real bilateral exchange rate can be explained reasonably well by its long-term fundamentals, such as the terms of trade, Canada's net foreign asset position, the relative price of nontraded to traded goods (which proxies relative productivity growth in the traded goods sector), risk premia, and real interest rates. This finding is buttressed by an alternative model for the real exchange rate that points to long-run supply shocks, such as terms of trade and productivity shocks, as being the most important factors behind the depreciation of the Canadian dollar in 1997 and 1998.

\section{A. Factors Influencing the Real Exchange Rate}

3. In the case of Canada, several important regularities stand out in examining the real bilateral exchange rate and some of its likely economic fundamentals (Tables 1 and 2) ${ }^{2}$. First, the cyclical ("transitory") and trend ("permanent") components of the relative price of

\section{${ }^{1}$ Prepared by Martin Cerisola, Phillip Swagel, and Alex Keenan.}

${ }^{2}$ Amano and Van Norden (1995) show that most of the historical variation in the real exchange rate in Canada is attributable to terms of trade shocks, with monetary factors usually playing a minor role. In general, studies have confirmed the importance of terms of trade shocks in accounting for deviations from purchasing power parity (Mendoza, 1995), with an additional but typically weak link between movements in real exchange rates and real interest rate differentials. While Campbell and Clarida (1987) and Meese and Rogoff (1988) found no statistically significant link between the real exchange rate and interest rate differentials, Baxter (1994) presents evidence showing a significant link between the cyclical components of real exchange and interest rate differentials but no cointegrating relationship between them in certain advanced economies. 
nontraded to traded goods ${ }^{3}$ are positively correlated with their counterparts in the real bilateral exchange rate, while the cyclical and trend components of the net foreign asset position and the risk premium (as proxied by Canada's net government debt relative to the United States) are highly negatively correlated with the real bilateral exchange rate (Figure 2). ${ }^{4}$ Second, the cyclical components of the terms of trade, the fiscal balance, and the real interest rate are significantly correlated with the cyclical component of the real bilateral exchange rate. Third, shocks to the real bilateral exchange rate, the relative price of nontraded to traded goods, the relative terms of trade, and the risk premium are highly persistent, as suggested by the high positive autocorrelations, while shocks to the real interest rate differential seem to disappear more rapidly. Overall, these stylized facts suggest that the terms of trade, the relative price of nontraded to traded goods, and risk premia may be important factors in explaining fluctuations in the Canadian real exchange rate.

\section{B. Modeling the Real Bilateral Exchange Rate}

4. Following Clark and MacDonald (1998), a real exchange rate equation was estimated for Canada that aims to explain real exchange rate fluctuations in terms of a relevant set of economic fundamentals. ${ }^{5}$ The model underlying the equation assumes that the real exchange

\footnotetext{
${ }^{3}$ The existence of nontraded goods may allow for two different sources of systematic change in real exchange rates. First, the Balassa-Samuelson effect assumes that the nominal exchange rate adjusts so as to ensure a constant relative price of traded goods over time. However, differences in productivity of traded goods across countries may introduce a bias to the real exchange rate when it is defined using overall price indices. If prices for traded and nontraded goods are linked to wages, and wages to productivity, faster productivity growth in the traded sector in one country would be reflected in higher growth in the relative price of nontraded to traded goods. As a result, the real exchange rate, so defined, would appreciate even if the relative price of traded goods were constant. Second, a demand side bias arising from an income elasticity of nontraded goods that exceeds unity will tend to raise the relative price of nontraded goods as income rises. This relative price is therefore likely to provide a reasonable proxy for the productivity bias between the Canadian and U.S. traded good sector and the difference in the share spent by Canadian and U.S. households on nontradable goods. An increase in any of these variables would induce an appreciation of the real exchange rate.
}

${ }^{4}$ See Annex I for the definition of variables.

${ }^{5}$ Clark and MacDonald (1998) refer to this as a behavioral equilibrium exchange rate (BEER) approach. As a result, the estimated real exchange rate reflects more of a behavioral equilibrium rather than a long-term equilibrium, since the long-term "equilibrium" values of the fundamental determinants of the exchange rate are not used in the estimation. This methodology is different from that used by the Consultative Group on Exchange Rates 
rate is determined by the expectation of the real exchange rate at a certain period in the future, the real interest rate differential for that same period, and the risk premium. In this model, the unobservable expectation of the exchange rate is assumed to be determined exclusively by the terms of trade, the relative price of nontraded to traded goods, and the net foreign asset position. ${ }^{6}$ Therefore, a vector autoregressive system (VAR) which includes the real exchange rate, the relative price of nontraded to traded goods, the terms of trade, the net foreign asset position, the net government debt, and the real interest rate differential was estimated to obtain the long-run relationship between these variables (cointegrating vector) (Table 3). A series for the real exchange rate was then derived using the estimated long-run coefficients and the actual values of the economic fundamentals. The coefficients on the long-run determinants are correctly signed and highly significant, suggesting that an increase in the relative terms of trade, the relative price of nontraded to traded goods, the net foreign asset position, and real interest rates in Canada tend to appreciate the real exchange rate over the long run. ${ }^{7}$

5. The estimated model accounts for most of the fluctuations in the Canadian real exchange rate between 1984 and the second quarter of 1998 (Figure 3). The fitted real exchange rate is derived from the estimated cointegrating vector and its long-run fundamental determinants, so that the differences between the actual and fitted rate reflect the effects of unobserved cyclical and random factors, in addition to the extent to which the economic fundamentals differ from their sustainable values. More specifically, the real depreciation that has taken place since early 1991 seems to be explained relatively well by its long-run determinants. A steady decline in the relative terms of trade and, possibly, in the productivity growth of the tradable sector in Canada relative to that of the United States as suggested by

\footnotetext{
s(...continued)
}

(CGER) at the Fund, which aims at estimating an equilibrium multilateral exchange rate indirectly by comparing the projected saving-investment balance for any country relative to its long-term "equilibrium."

\section{${ }^{6}$ See Clark and MacDonald (1998) for further details.}

${ }^{7}$ The model appears to be relatively well specified, as the diagnostic tests for the underlying VAR show that residuals have no serial correlation, are homoskedastic, and are normally distributed (Table 3). However, the results are sensitive to the sample period, the number of lags included in the VAR, and to the expected inflation rate component of the real interest rate differential. A lag equal to two was chosen in order to maximize degrees of freedom in the VAR given the small sample size relative to the number of variables used in the estimation. As seen in Table 4, the presence of serial correlation in the REER equation in the VAR may be reflecting the relatively low degrees of freedom in the system and may be also contributing to the lack of a statistically significant feedback effect (the alpha coefficient) from the lagged deviations of the real exchange rate level from the cointegrating vector onto the variables in the VAR, in particular the change in the real exchange rate. 
the relative price of nontraded to traded goods, together with a rapid buildup in net government debt relative to the United States, were the most important contributing factors behind the real depreciation since 1991. In addition to these factors, a narrowing real interest rate differential vis-à-vis the United States and a deteriorating net foreign asset position seem to have also contributed to the real depreciation observed between late 1996 and mid-1998. Even when removing the cyclical component from the long-run economic fundamentals using the Hodrick and Prescott filter (Figure 3), the model still accounts for most of the real depreciation through mid-1998. However, the model is not able to capture fully the real depreciation that took place in the third quarter of 1998 , which may be partly explained by the sharp cyclical decline in the terms of trade.

\section{An Alternative Approach to Modeling the Real Exchange Rate}

6. An alternative methodology for identifying the nature of shocks driving fluctuations in the real exchange rate follows Clarida and Gali (1996), in which a structural VAR that includes real output, the real bilateral exchange rate, and the general price level, is used to assess the extent to which supply, demand, and nominal shocks have been responsible for the weakness of the Canadian dollar. ${ }^{8}$ Movements in output, the real exchange rate, and prices can be thought of as corresponding to "supply," "demand," and "nominal" shocks, respectively. Intuitively, a supply shock is defined as a shock that has long-run implications for the level of production, whereas demand and nominal shocks have temporary effects on output. The restrictions imposed on the model are that price shocks do not have permanent effects on output or the real exchange rate; real exchange rate shocks can have permanent effects on the real exchange rate and price level but not on the level of output; and output shocks can have permanent effects on all three variables. In the VAR, restrictions consistent with the analytical model are imposed on the long-run responses of the three variables to unexpected shocks in each of the three variables in the system, while the short-run dynamics of all variables are left unconstrained. The VAR is also used to gauge the average importance of these shocks in accounting for exchange rate movements at various forecast horizons over the period from 1976 to 1998 .

7. In assessing the effects of unexpected shocks on the value of the Canadian dollar in 1997 and 1998 (as opposed to simply the effects of past changes in the three variables), the VAR estimates show that adverse supply shocks have accounted for approximately a

${ }^{8}$ The econometric model here was estimated using quarterly data from the first quarter of 1976 to the third quarter of 1998 . This model is based on an extended Mundell-Fleming framework and includes three variables: growth of real GDP in Canada relative to GDP growth in the United States, the percent change in the Canada-U.S. real exchange rate, and the relative rates of inflation in the two countries. Each variable was regressed on a constant, 12 quarterly lags of itself and the other 2 variables in the system. For additional technical details, see Clarida and Gali (1996). 
7 percent cumulative decline of the Canadian dollar. Supply shocks in this framework are any influences that have permanent effects on the level of output, such as changes in commodity prices that affect the two countries differently as well as changes in relative productivity. In addition, relative nominal shocks (shocks to the relative money supply and the demand for real balances) between Canada and the United States have contributed to a 3 percent depreciation over the same period (Figure 4). These two types of shocks have been somewhat offset by favorable relative demand shocks, which have accounted for a 2 percent appreciation of the Canadian dollar. 


\section{List of References}

Amano, R. and van Norden, S., 1995, "Terms of Trade and Real Exchange Rates: The Canadian Evidence," Journal of International Money and Finance, Vol. 14, No. 1, pp. 83-104.

Baxter, M., 1994, "Real Exchange Rates and Real Interest Differentials. Have We Missed the Business-Cycle Relationship?," Journal of Monetary Economics, 33, pp. 5-37.

Boessenkool, K. And Robson, W., 1998, "Let's Defend the Dollar-With Lower lnwRates!," C.D.Howe Institute, Backgrounder.

Campbell, J. And Clarida, R., 1987, "The Dollar and Real Interest Rates," CarnegieRochester Conference Series on Public Policy, 27, pp. 103-140.

Clarida, R, and Gali, J., 1996, "Sources of Real Exchange Rate Fluctuations: How Important are Nominal Shocks?" Carnegie-Rochester Conference Series on Public Policy, Vol. 41 (December), pp. 1-56.

Clark, P. and MacDonald, R., 1998, "Exchange Rates and Economic Fundamentals: A Methodological Comparison of BEERs and FEERs", IMF Working Paper 98/67.

Johansen, S., 1995, "Likelihood-Based Inference in Cointegrated Vector Autoregressive Models", (Oxford University Press).

Meese, R. and Rogoff, K., 1988, "Was is Real? The Exchange Rate-Interest Rate Differential Relation Over the Modern Floating Rate Period", Journal of Finance, 43, 933-948.

Mendoza, E., 1995, "The Terms of Trade, The Real Exchange Rate, and Economic Fluctuations," International Economic Review, 36, pp. 101-137. 
Annex I: Data Sources and Definitions

The sample period is from the first quarter of 1984 to the third quarter of 1998 , based on data available as of December 15,1998 . The sources and definitions are as follows:

real exchange rate (REER) is the bilateral rate, expressed as U.S. dollars per Canadian dollars, adjusted by the differential inflation rates in the respective gross domestic product implicit price deflators. An increase in the variable denotes an appreciation. The variable is expressed in logs. Sources: Statistics Canada and U.S. National Income and Product Accounts.

terms of trade (TOT) is the logarithm of the ratio of Canada's export price index for goods $(1992=100)$ to the import price index relative to the same ratio of the export to import prices of goods for the United States. Sources: Bank of Canada Review, Statistics Canada, and Bureau of Labor Statistics, U.S. Department of Labor.

relative price of nontraded to traded goods (TNT) is the logarithm of the ratio of the Canadian consumer price index to the wholesale or producer price index relative to the equivalent ratio in the United States. Sources: Statistics Canada and U.S. Bureau of Labor Statistics.

net foreign assets (NFA) is the ratio of net foreign assets, excluding monetary gold, to GDP in Canada relative to the same ratio for the United States. Source: OECD, staff estimates after 1994.

relative fiscal balance (RFB) is the ratio of Canada's federal budget balance on a national accounts basis to GDP relative to the same ratio of the federal government balance to GDP for the United States. Sources: Statistics Canada and U.S. National Income and Product Accounts.

relative stock of government debt (NGD) is the ratio of net general government debt to GDP in Canada relative to the same ratio of the net general government debt to GDP in the United States. Sources: Statistics Canada and U.S. Flow of Funds, Federal Reserve Board.

real interest rates (RIR): is the Canadian ten-year government bond yield deflated by a twoquarter moving average of CPI inflation relative to the same estimate of the real long-term interest rate for the United States. Sources: Statistics Canada and Haver Analytics. 
Table 1. Canada: Correlations with Canada's Real Exchange Rate

\begin{tabular}{lcccccc}
\hline & \multicolumn{5}{c}{ Correlation with 1/ } \\
\cline { 2 - 7 } & $\begin{array}{c}\text { Terms } \\
\text { of } \\
\text { Trade }\end{array}$ & $\begin{array}{c}\text { Relative } \\
\text { Price } \\
\text { Nontraded- } \\
\text { Traded }\end{array}$ & $\begin{array}{c}\text { Fiscal } \\
\text { Balance }\end{array}$ & $\begin{array}{c}\text { Net } \\
\text { Foreign } \\
\text { Assets }\end{array}$ & $\begin{array}{c}\text { Not } \\
\text { Govern- } \\
\text { ment } \\
\text { Debt }\end{array}$ & $\begin{array}{c}\text { Real } \\
\text { Interest } \\
\text { Rate }\end{array}$ \\
\cline { 2 - 7 } Real exchange rate & & & & & & \\
Actual & 0.29 & 0.78 & -0.30 & -0.59 & -0.69 & 0.01 \\
Trend & 0.04 & 0.96 & -0.69 & -0.66 & -0.71 & 0.03 \\
Cycle & 0.60 & 0.29 & 0.12 & -0.40 & -0.75 & -0.10 \\
\hline
\end{tabular}

Sources: Statistics Canada; and staff estimates.

1/ From the first quarter of 1984 to the third quarter of 1998 . The trend and cycle correlations correspond to detrended data using the Hodrick-Prescott filter. Each variable is defined relative to that of the United States. Since these variables are nonstationary, the correlations for the trend components may not be very meaningful. They are presented to summarize the patterns of movement between the variables within the sample.

Table 2. Canada: Autocorrelation of Canada's Real Exchange Rate and Its Major Determinants

\begin{tabular}{lccccc}
\hline & \multicolumn{5}{c}{ Autocorrelation Order 1/ } \\
\cline { 2 - 6 } Cyclical component of: & First & Second & Third & Fourth & Fifth \\
\cline { 2 - 6 } Real exchange rate & 0.87 & 0.74 & 0.61 & 0.43 & 0.26 \\
Terms of trade & 0.68 & 0.34 & 0.17 & 0.03 & -0.07 \\
Relative price nontraded to traded goods & 0.95 & 0.81 & 0.65 & 0.48 & 0.30 \\
Fiscal balance & 0.42 & 0.13 & 0.03 & -0.23 & -0.38 \\
Net foreign assets & 0.89 & 0.67 & 0.43 & 0.21 & 0.04 \\
Net government debt & 0.87 & 0.70 & 0.51 & 0.34 & 0.15 \\
Real interest rate & 0.47 & -0.23 & -0.43 & -0.27 & 0.03 \\
& & & & & \\
\hline
\end{tabular}

Sources: Statistics Canada; and staff estimates.

1/ The auto-correlations correspond to detrended data using the Hodrick-Prescott filter. Each variable is defined relative to that of the United States. 
Table 3. Canada: Cointegration Analysis

Multivariate stationarity test $1 /$

Variable

\begin{tabular}{rrrrrr} 
REER & TOT & TNT & NFA & NGD & RIR \\
\hline 89.84 & 83.60 & 89.30 & 85.30 & 86.20 & 63.20 \\
$(0.000)^{* *}$ & $(0.000)^{* *}$ & $(0.000)^{* *}$ & $(0.000)^{* *}$ & $(0.000)^{* *}$ & $(0.000)^{* *}$
\end{tabular}

\section{Cointegration analysis $2 /$}

$\begin{array}{lrrrrrr}\text { Ho: } r= & 0 & 1 & 2 & 3 & 4 & 5 \\ \text { Eigenvalue } & 0.786 & 0.394 & 0.374 & 0.241 & 0.149 & 0.048 \\ & & & & & & \\ \text { Trace } & 176.7^{* *} & 85.8 * * & 56.3^{*} & 28.7 & 12.4 & 2.9 \\ \text { Trace II } & 140.8 * & 68.4 & 44.8 & 22.8 & 9.9 & 2.3\end{array}$

Cointegrating vector for [REER, TOT, TNT, NFA, NGD, RIR, CONSTANT]

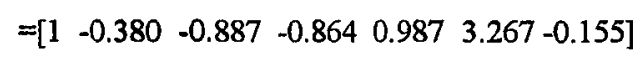

Standard Errors for cointegrating vector

$$
=\left[\begin{array}{lllllll}
0 & 0.133 & 0.109 & 0.221 & 0.095 & 0.281 & 0.071
\end{array}\right]
$$

Estimated Real Exchange Rate Equation

$$
\text { REER }=0.155+0.38 \text { TOT }+0.887 \text { TNT }+0.864 \mathrm{NFA}-0.987 \mathrm{NGD}+3.267 \mathrm{RIR}
$$

1/ An asterick or double asterisk denotes rejection of the null hypothesis of no unit root at the 5 and 1 percent level of significance, respectively. Augmented Dickey Fuller tests also reject the null of stationarity for each variable.

2/ The Trace and Trace II statistics are Johansen's trace eigenvalue before and after adjustment for degrees of freedom, respectively. The null hypothesis is in terms of the cointegration rank $r$ implying that rejection of $r=0$ is evidence in favor of at least one cointegrating vector. 
Table 4. Canada: Residual Diagnostic Tests

\begin{tabular}{lcccc}
\hline & \multicolumn{4}{c}{ Residual Diagnostics 1/ } \\
\cline { 2 - 5 } & LM(4) & Normality & ARCH (4) & Chi-Square \\
\cline { 2 - 5 } Real exchange rate & 2.69 & & & \\
& $(0.04)^{*}$ & 0.42 & 0.29 & 0.91 \\
Terms of trade & 0.45 & $(0.81)$ & $(0.88)$ & $(0.60)$ \\
& $(0.77)$ & 2.86 & 0.52 & 0.54 \\
Relative price nontraded & 0.73 & $(0.24)$ & $(0.72)$ & $(0.93)$ \\
& $(0.58)$ & 1.01 & 0.42 & 0.47 \\
Net foreign assets & 1.74 & $(0.60)$ & $(0.79)$ & $(0.96)$ \\
& $(0.16)$ & 1.98 & 1.08 & 0.51 \\
Net government debt & 0.30 & $(0.37)$ & $(0.38)$ & $(0.94)$ \\
& $(0.88)$ & 0.78 & 2.67 & 0.66 \\
Real interest rate & 1.41 & $(0.68)$ & $(0.05)^{*}$ & $(0.84)$ \\
& $(0.25)$ & 2.79 & 1.54 & 1.63 \\
VAR & 1.33 & $(0.25)$ & $(0.21)$ & $(0.14)$ \\
& $(0.06)$ & 10.01 & -- & $547.502 /$ \\
& & $(0.61)$ & -- & $(0.09)$ \\
\hline
\end{tabular}

1/ Significance levels reported in parentheses. LM corresponds to the Lagrange-multiplier test for serial correlation. ARCH stands for autoregressive conditional heteroskedasticy. Chi-square is also a test or heteroskedasticity. An asterisk denotes rejection of the null of no serial correlation at a 1 percent level of significance.

$2 /$ Corresponds to the test for heteroskedasticity based on a multivariate regression of all error variances and covariances on the original regressors and their squares. 
FIGURE 1

CANADA

REAL EXCHANGE RATE

TREND AND CYCLICAL COMPONENTS

(in logarithm)

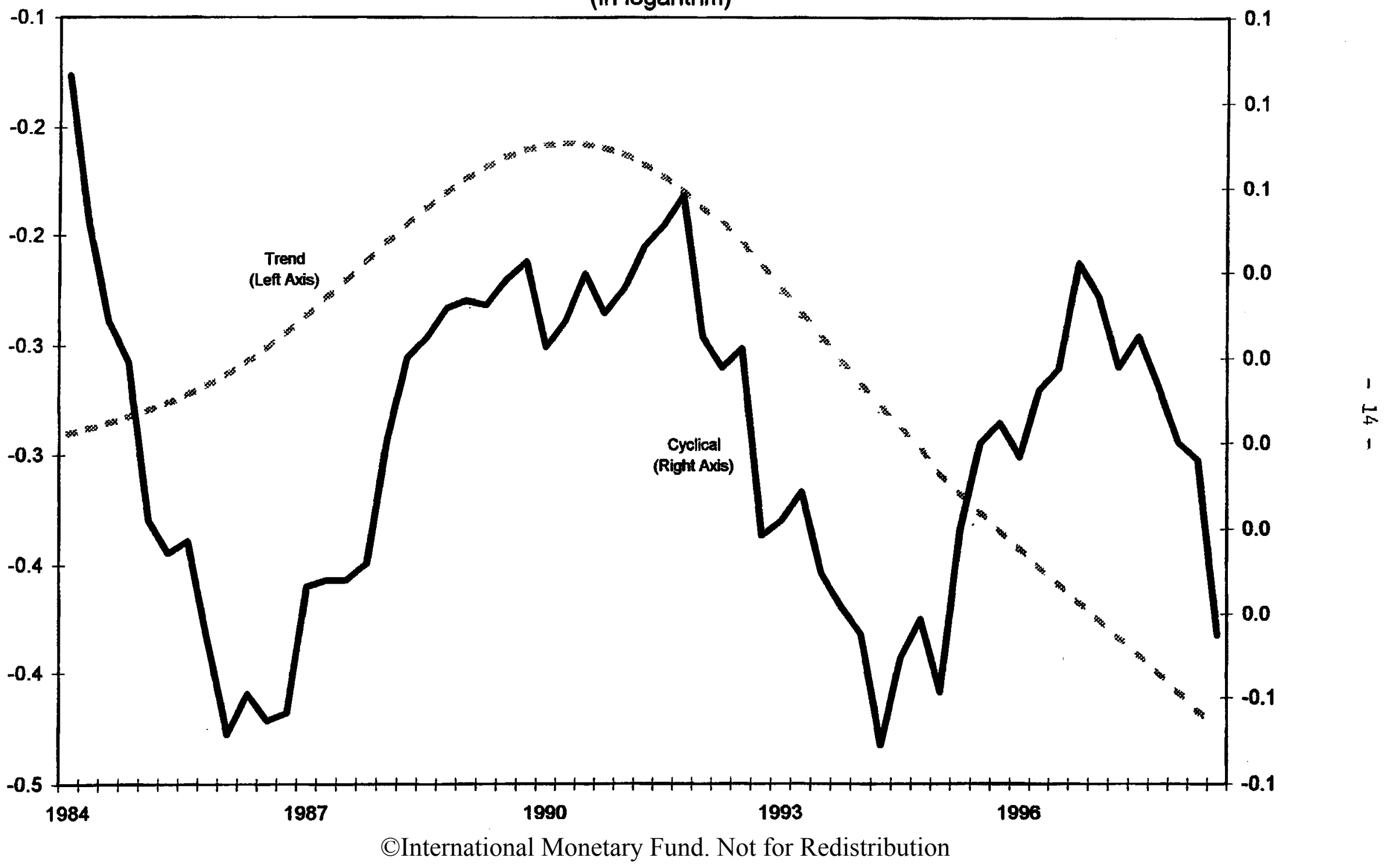




\section{FIGURE 2}

CANADA

REAL EXCHANGE RATE AND LONG-RUN DETERMINANTS 1/

Terms of Trade and Relative Price of

Nontraded Goods: Cyclical Components

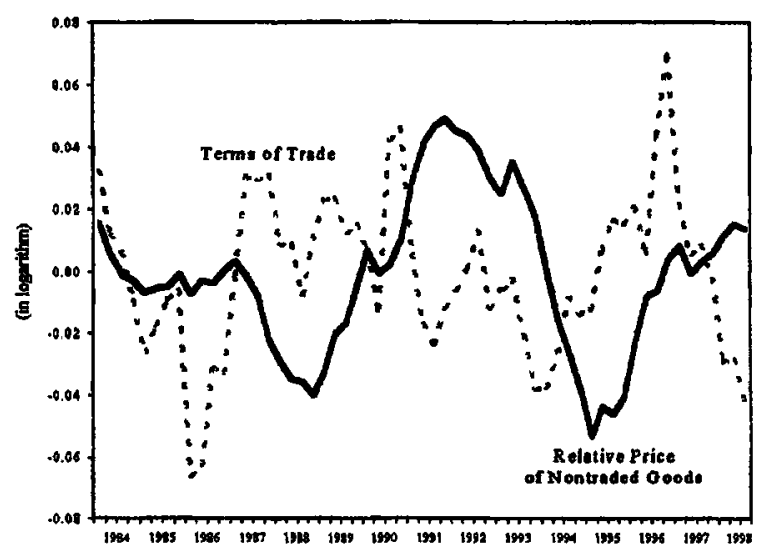

Real Exchange Rate and Terms of Trade:

Permanent Components

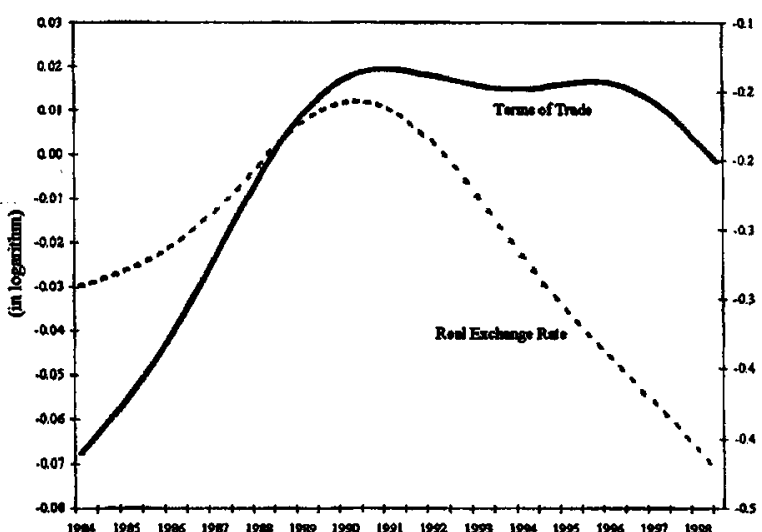

Real Interest Rates

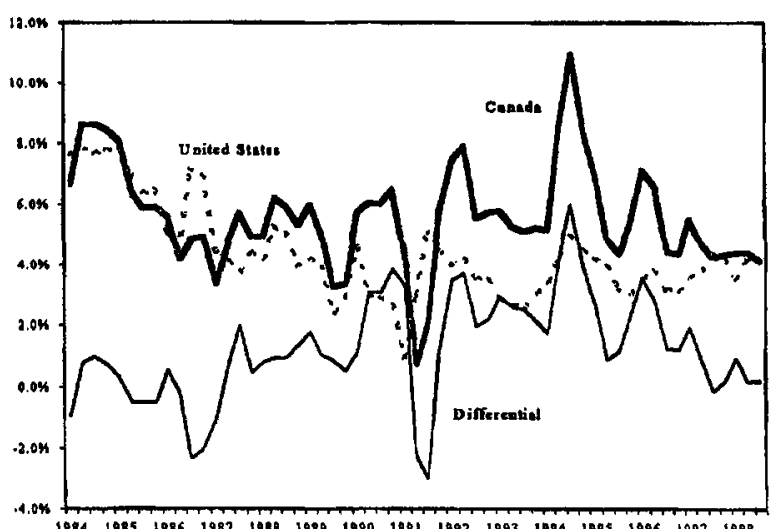

Real Exchange Rate, Net Government Debt, and

Relative Price of Nontraded Goods: Trend Components

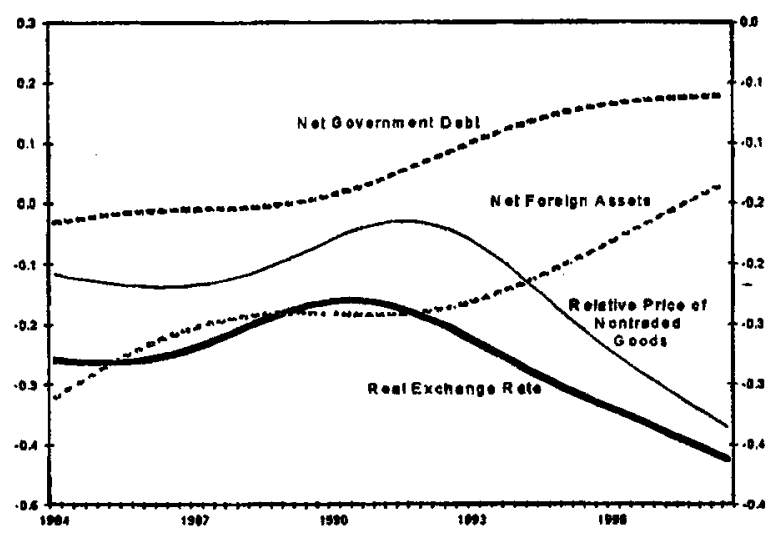

Real Exchange Rate and Net Government Debt: Cyclical Components

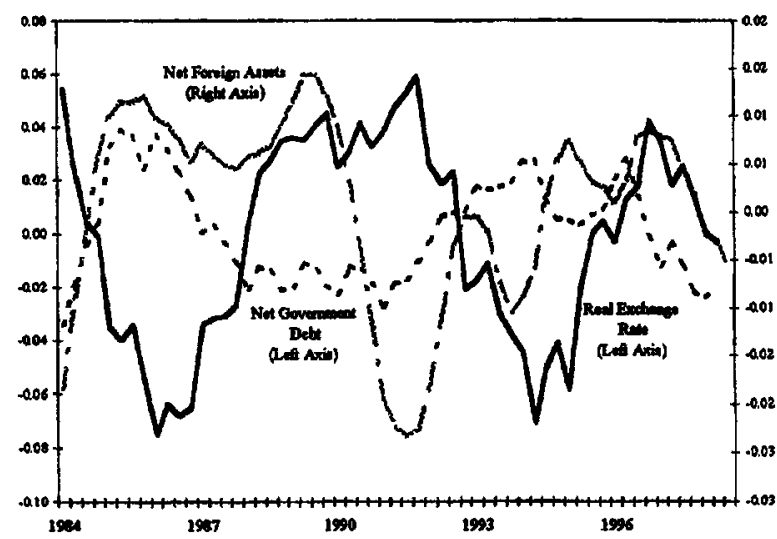

Terms of Trade

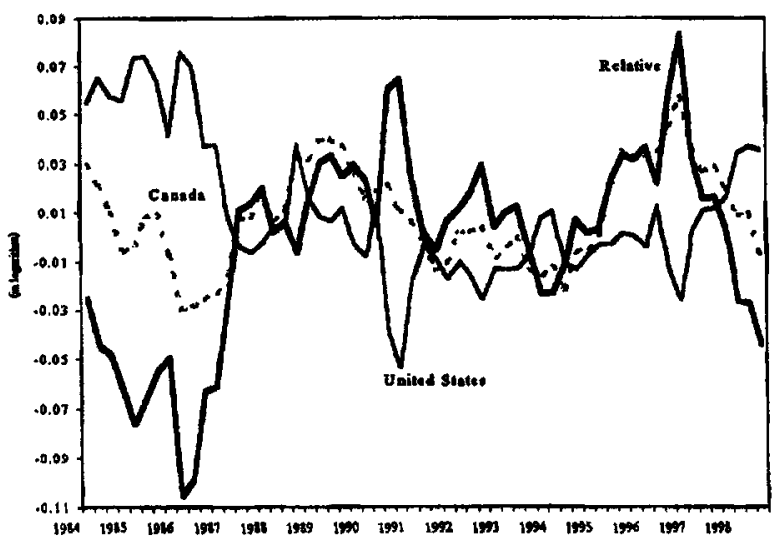

1/ The trend and cyclical components were calculated using the Hodrick-Prescott filter.

(C) International Monetary Fund. Not for Redistribution 
FIGURE 3

CANADA

REAL EXCHANGE RATE

Real Exchange Rate: 1984:1-1998:3 1/
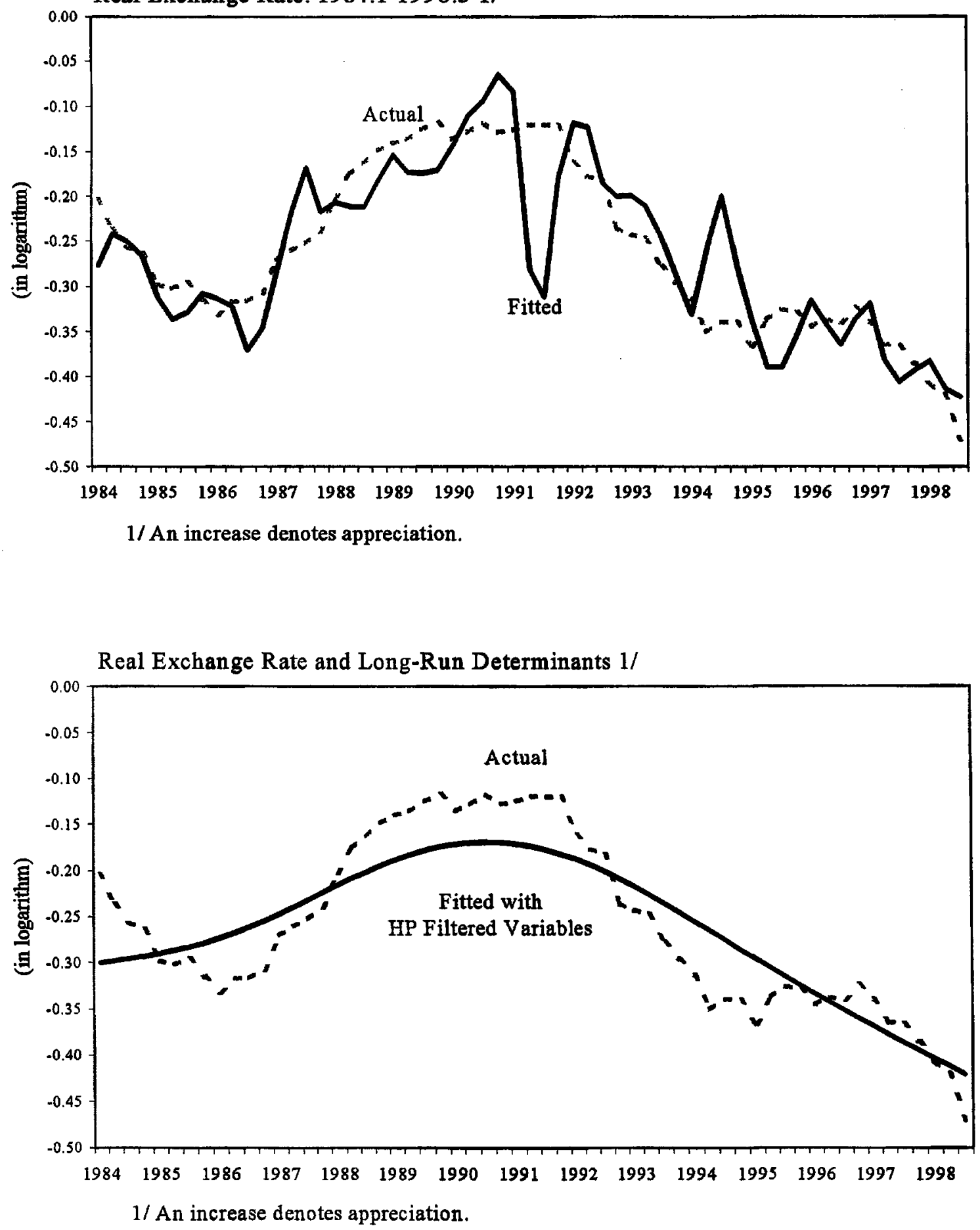

CInternational Monetary Fund. Not for Redistribution 
CANADA

CUMULATIVE EFFECT OF SHOCKS ON THE REAL EXCHANGE RATE

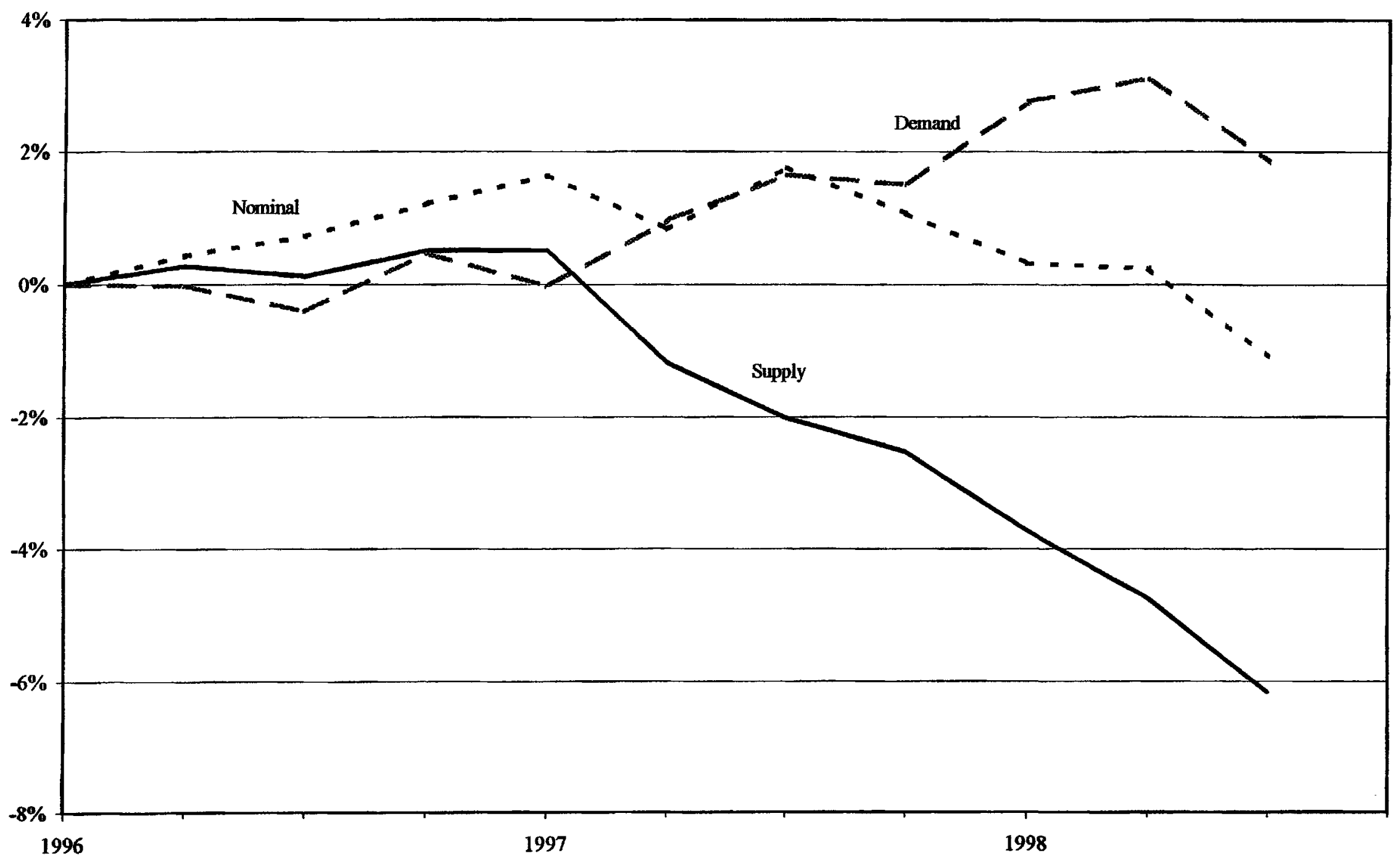




\section{INFLATION AND THE NATURAL RATE OF UNEMPLOYMENT IN CANADA ${ }^{1}$}

1. This paper examines whether the recent low inflation in Canada is consistent with a traditional Phillips-curve relationship between activity and inflation. Inflation in Canada has remained below 2 percent since 1995, and for the past two years, it has been near the bottom of the Bank of Canada's 1 to 3 percent target range. Over this period, there has been sustained growth in the economy, with the unemployment rate declining from nearly 10 percent in mid-1996 to 8 percent in late 1998, a level that is close to most estimates of the natural rate of unemployment in Canada (Figure 1). In these circumstances, it would be expected that there would be upward pressure on prices, as slack in the labor market was reduced.

2. The results presented here suggest that the absence of price pressures in part may reflect supply-side influences, such as a decline in import prices. However, the estimated Phillips-curve equations consistently overpredict the inflation rate after the first half of 1997. One possible explanation for these results might be that the natural rate of unemployment is lower than its conventional estimated level. As discussed below, assuming a natural rate of unemployment for 1997 and 1998 of around 6.5 percent basically reconciles the model forecasts to the actual inflation performance.

3. Table 1 presents results for three Phillips-curve equations estimated using quarterly data for the period 1976 to 1996. In these regressions, CPI inflation depends on the unemployment gap alone, or on the unemployment gap plus the rate of change of either import prices or the nominal exchange rate with the U.S. dollar. ${ }^{2}$ Import prices and exchange rates are included since these represent supply-side shocks to the cost of imported goods, which would be expected to affect consumer prices directly through their effect on the price of imported final goods, and indirectly through their effect on the price of imported intermediate goods. ${ }^{3}$ The first column of the table shows estimates of the traditional Phillips

\section{${ }^{1}$ Prepared by Phillip Swagel.}

${ }^{2}$ The unemployment gap is defined as the unemployment rate minus the conventional estimate of the natural rate, so that a larger gap corresponds to weaker activity. The values for the natural rate are IMF staff estimates, with linear interpolation used to produce quarterly values from the annual series estimated for the natural rate. Inflation, import prices, and exchange rates are expressed as the annualized percentage changes of the respective quarterly indexes. Four lags are used for each of the explanatory variables in the regressions.

${ }^{3}$ Specifications were also estimated with core inflation (which excludes food and energy costs and changes in indirect taxes), but the coefficient on the unemployment gap is not significant in any of these regressions. Similarly, additional supply-side influences on inflation, including commodity prices (oil, non-oil, and all commodities) and changes in indirect taxes, were not 
curve in which inflation depends only on activity, while columns 2 and 3 add import prices and exchange rates, respectively. The point estimates for the unemployment gap have the expected sign in all cases, but the coefficient is significantly different from zero only in the specification which includes the change in the exchange rate (column 3). However, the regression diagnostics are satisfactory in all cases, with a high degree of fit and the Godfrey-Breusch test statistics indicating an absence of serial correlation.

4. Figure 2 shows fitted values from the equations including import prices and the exchange rate, with the values for 1997 and 1998 calculated as static projections. In both cases, the equations explain inflation reasonably well through the first half of 1997; however, both equations predict that inflation should have been 0.5 to 1.3 percentage points higher in 1998 than was actually the case. The breakdown in the passthrough of exchange rates into import prices partly explains why the equation including changes in the exchange rates predicts higher inflation than the equation with changes in import prices, but both equations predict higher-than-actual inflation owing to a narrowing of the unemployment gap.

5. While it is possible that the overprediction of inflation by the equations may reflect the influence of other factors not included in the equations, it could also be attributed to an overestimate of the natural rate of unemployment. To test implications for the estimate of the natural rate, a dynamic forecast for inflation was made using the Philips-curve equation including import prices, and this forecast was compared to an alternative forecast based on the assumption of a 1 percentage point lower natural rate of unemployment (Figure 3). ${ }^{4}$ For 1997, the simulation with the lower natural rate leads to forecast values for inflation that are somewhat lower than actual inflation, but the decline in actual unemployment relative to the 1 percentage point lower natural rate is so great that forecast inflation still rises substantially above actual inflation in 1998. To fully account for actual inflation in 1998, the unemployment gap would have to remain around 2 percent in 1997 and 1998, implying a natural rate of around 6.5 percent in 1998 instead of the conventional estimate of around 8 percent.

\footnotetext{
${ }^{3}$ (...continued)

statistically significant in specifications that include import prices or the exchange rate.

${ }^{4}$ The baseline forecast of inflation in Figure 3 is substantially higher than actual inflation, and is also above the corresponding static forecast in Figure 2. This is because higher predicted inflation feeds through to future periods in the dynamic forecast, while in the static forecast, the lower values of actual inflation are used for the lags terms in the equation.
} 
Table 1. Canada: Estimates of Phillips-Curve Regressions 1/

\begin{tabular}{lccr}
\hline & \multicolumn{3}{c}{$\begin{array}{c}\text { Overall Inflation } \\
(1976 \mathrm{Q} 1-1996 \mathrm{Q})\end{array}$} \\
\cline { 2 - 4 } & $(1)$ & $(2)$ & $(3)$ \\
\hline Lagged inflation & 0.924 & 0.850 & 0.885 \\
& $(12.84)$ & $(8.09)$ & $(11.66)$ \\
Unemployment gap & -0.219 & -0.143 & -0.475 \\
& $(-1.30)$ & $(-0.75)$ & $(-2.10)$ \\
Import price growth & & 0.063 & $(0.99)$ \\
Exchange rate growth & & & 0.098 \\
& & & $(1.60)$ \\
\hline Adjusted $\mathrm{R}^{2}$ & & 0.73 & 0.75 \\
Godfrey-Breusch test for first order & 0.74 & & 0.37 \\
serial correlation 2/ & & 0.39 & \\
\hline
\end{tabular}

1/ The table shows the sum of coefficients on four lags of the variables. The t-statistic for each coefficient is in parentheses. Inflation, import price growth, and exchange rate growth are annualized percent rates of change. 2/ The Godfrey-Breusch test shows the significance level at which the mull hypothesis of no serial correlation can be rejected. A value for the test statistic of less than 0.05 is the usual standard for concluding that the estimates are affected by serial correlation, while a value close to 1.0 indicates the absence of serial correlation. 


\section{FIGURE 1}

CANADA

\section{INFLUENCES ON INFLATION}

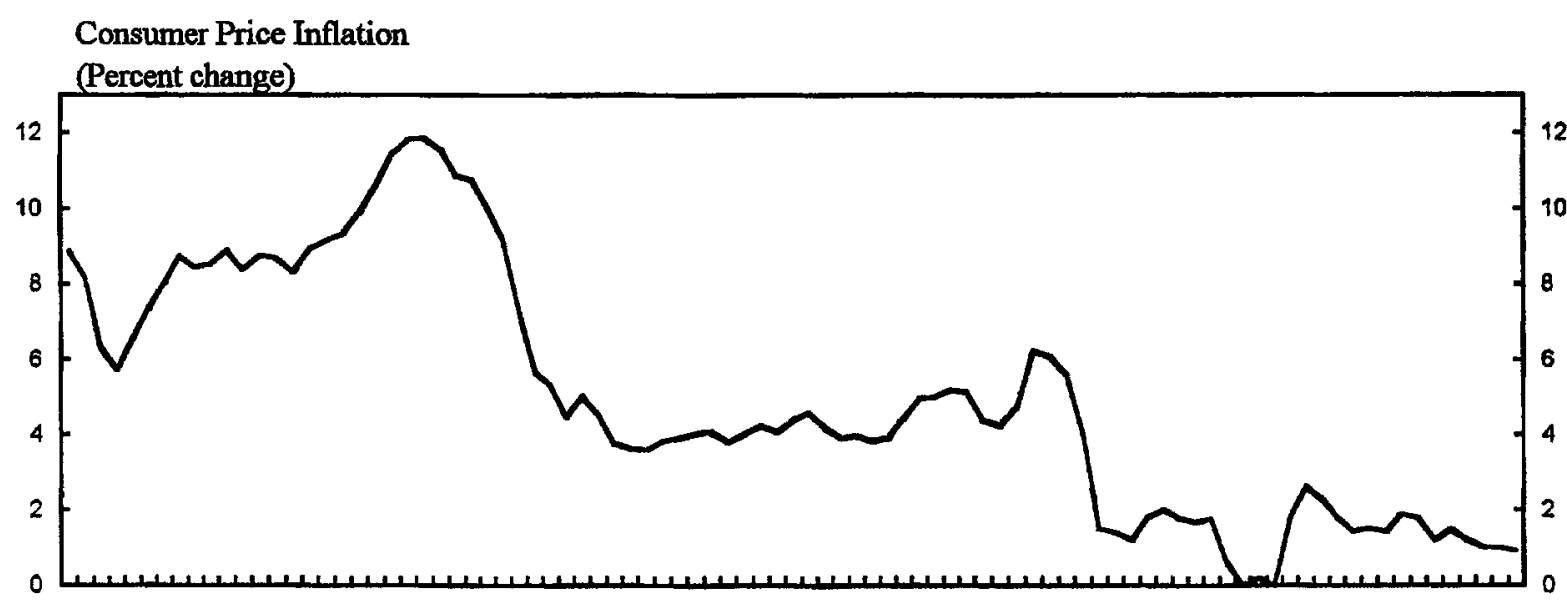

19761977197819791980198119821983198419851986198719881989199019911992199319941995199619971998
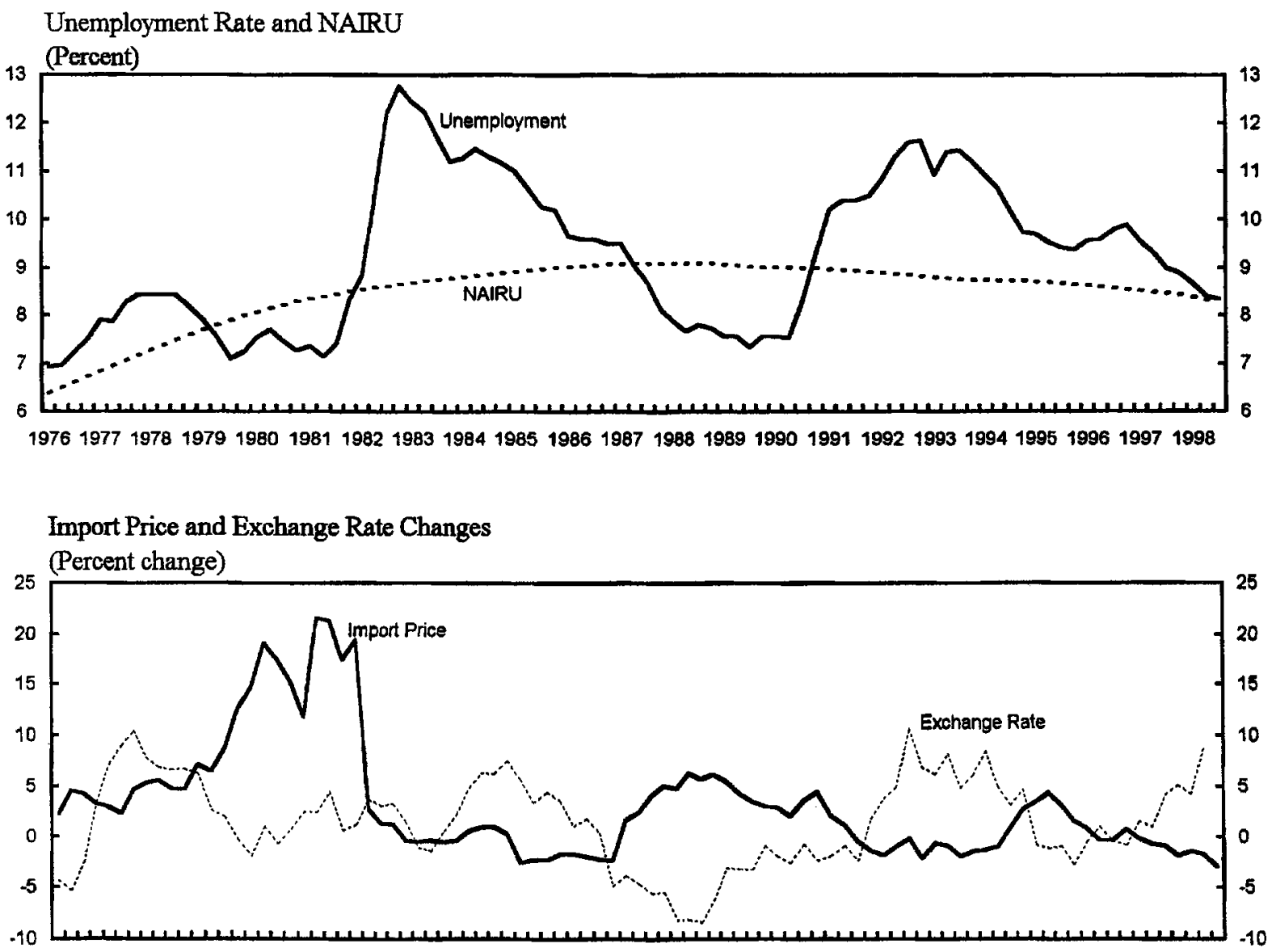

19761977197819791980198119821983198419851986198719881989199019911992199319941995199619971998

Sources: Statistics Canada; and Fund staff estimates. 
FIGURE 2

CANADA

PHILLIPS-CURVE REGRESSION FORECASTS

(Percent change)

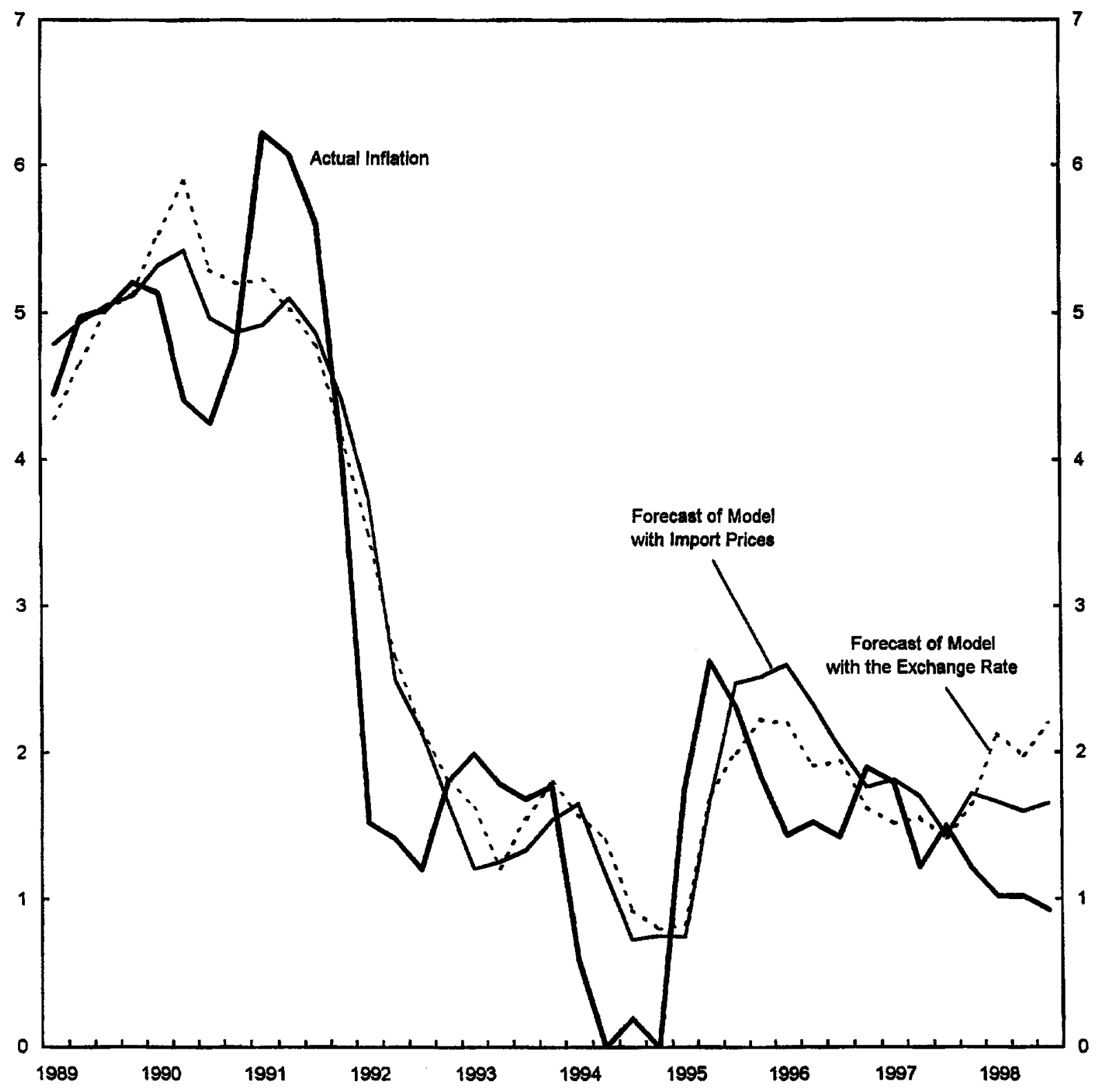

Source: Fund staff estimates. 
FIGURE 3

CANADA

EFFECT OF ONE PERCENT LOWER NAIRU

(Percent)

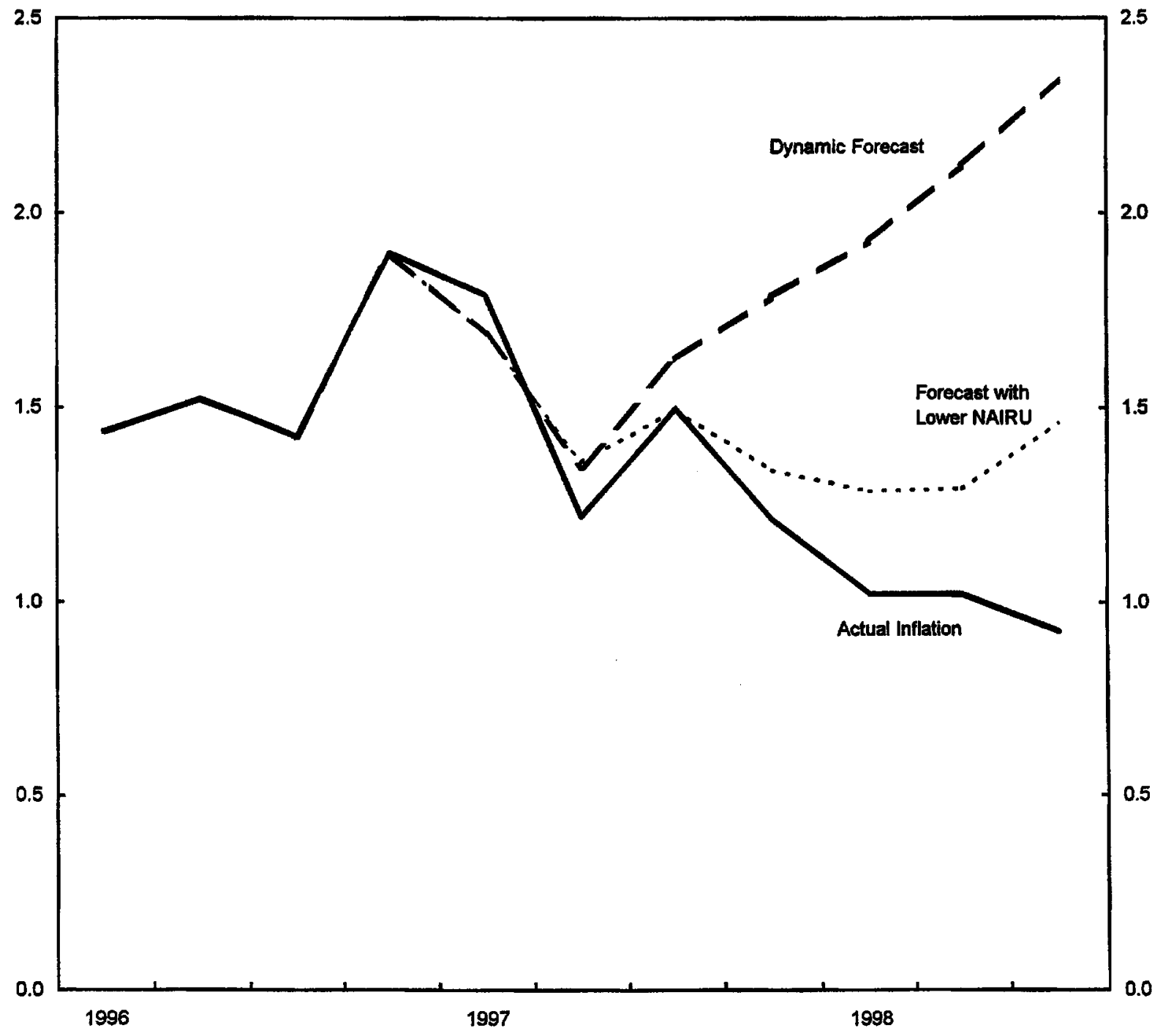

Source: Fund staff estimates.

CInternational Monetary Fund. Not for Redistribution 


\section{BUSINESS TAXATION IN CANADA: AN UPDATE ${ }^{1}$}

1. On March 16, 1996, the Canadian government established a Technical Committee on Business Taxation to analyze taxes related to investment and business activity and to recommend changes. The Committee was asked to consider ways of improving, in a revenue-neutral way, ${ }^{2}$ the business tax system to promote: (i) job creation; (ii) economic growth; (iii) simplification and ease of compliance; and (iv) fairness. The Committee also was charged with examining the interaction between business taxes-including corporate income, capital, and payroll taxes-and taxes paid by individuals on investment income. The Technical Committee's report was released to the public on April 6, 1998. This note briefly summarizes the state of business taxation in Canada and reviews the recommendations presented in the report.

\section{A. Business Taxation in Canada ${ }^{3}$}

2. The overall business tax environment includes corporate income taxes, payroll taxes, taxes on capital, and selected aspects of the personal income tax, particularly the taxation of dividends and capital gains. It also includes various tax preferences (credits and deductions) that tend to lower the effective corporate income tax rate relative to the statutory rate. In general, corporate income tax rates in Canada vary according to a firm's size, its production activity, and its provincial location.

3. The federal corporate statutory income tax rate is 28 percent for general business income. However, a number of statutory tax preferences offer reductions from the general rate. Small domestically owned incorporated businesses, or Canadian-controlled private corporations (CCPCs), qualify for a rate reduction of 16 percentage points (to 12 percent) on the first $\$ 200,000$ of taxable income. For income in excess of the small-business threshold, the general federal rate is reduced by 7 percentage points (to 21 percent) for income derived from manufacturing and processing. The provinces also frequently grant reductions in provin-cial corporate income tax rates for small businesses and in some cases for manufacturing and processing activities. When both federal and provincial rates are considered, there is significant variation in statutory tax rates on corporate income across Canada. Small business income earned in Newfoundland, for example, faces a 12 percent federal tax together with a

${ }^{1}$ Prepared by Michael Leidy.

2"Revenue neutral" implies that the proposed changes would have no effect on overall revenues from all sources of business taxation.

${ }^{3}$ This section draws on Cole and Leidy (1997). An overview of the corporate income tax system is presented in Department of Finance (1998, Chapter 5) and the Report of the Technical Committee (1998, Chapter 2). 
5 percent provincial tax, while general business income earned in New Brunswick faces a 28 percent federal tax along with a 17 percent provincial tax (see tabulation below). Federal and provincial governments also levy an annual tax of 0.225 percent on the paid-up capital of Canadian corporations.

4. Tax credits restrict the size of the corporate tax base by crediting certain corporate expenditures against the general corporate tax obligation. The current tax code grants tax credits, for example, for certain expenditures on research and development, for investment in eligible depreciable property used in Atlantic Canada, for certain exploration expenditures, and for certain contributions to registered political parties. ${ }^{4}$ Moreover, tax credits not used in the current tax year may be carried forward.

\begin{tabular}{|c|c|c|c|}
\hline \multicolumn{4}{|c|}{ Federal and Provincial Corporate Income Tax Rates, 1998} \\
\hline & $\begin{array}{c}\text { General } \\
\text { Business } \\
\end{array}$ & $\begin{array}{l}\text { Manufac- } \\
\text { turing and } \\
\text { Processing }\end{array}$ & $\begin{array}{c}\text { General } \\
\text { Small } \\
\text { Business } \\
\end{array}$ \\
\hline Federal $1 /$ & 28.00 & 21.00 & 12.00 \\
\hline Newfoundland & 14.00 & 5.00 & 5.00 \\
\hline Prince Edward Island & 16.00 & 7.50 & 7.50 \\
\hline Nova Scotia & 16.00 & 16.00 & 5.00 \\
\hline New Brunswick & 17.00 & 17.00 & 7.00 \\
\hline Québec & 9.15 & 9.15 & 5.91 \\
\hline Ontario & 15.50 & 13.50 & 9.50 \\
\hline Manitoba & 17.00 & 17.00 & 9.00 \\
\hline Saskatchewan & 17.00 & 10.00 & 8.00 \\
\hline Alberta & 15.50 & 14.50 & 6.00 \\
\hline British Columbia & 16.50 & 16.50 & 9.00 \\
\hline Yukon & 15.00 & 2.50 & 6.00 \\
\hline Northwest Territories & 14.00 & 14.00 & 5.00 \\
\hline $\begin{array}{l}\text { Source: Report of the } \\
1 / \text { In addition, a feder } \\
\text { processing rate to } 22.1\end{array}$ & $\begin{array}{l}\text { ing the gen } \\
\text { ousiness rat }\end{array}$ & sate to 29 & ffacturing anc \\
\hline
\end{tabular}

5. A variety of income exemptions and deductions also reduce the size of the corporate tax base and increase complexity. These include an additional deduction from taxable income for certain exploration and development expenditures; deductions of corporate charitable giving; deductions of gifts to the Crown; and deductions of interest on loans for small business financing. The rules governing corporate income tax deferrals also affect the size of the tax

${ }^{4} \mathrm{Tax}$ credits are discussed in detail in Department of Finance (1998), pp. 81-88. 
base and potentially affect the amount and timing of capital expenditure decisions. Certain business investment losses may also be deducted from current income.

6. Payroll taxes in Canada include employment insurance premiums, Canada Pension Plan (CPP) contributions, ${ }^{5}$ workers' compensation premiums, the provincial health/post-secondary education tax levied by some provinces, and general payroll taxes collected by some provinces. ${ }^{6}$ The structure and level of payroll taxes vary considerably across provinces and, with the exception of workers' compensation, taxes paid across firms are not closely linked to potential benefits received.

7. The individual income tax treatment of dividends and capital gains can affect the flow of financing for corporations and thus alter business investment decisions. Three-quarters of net capital gains, beyond a $\$ 500,000$ lifetime exemption for farms and small corporations, are taxed as personal income. Gains realized from the sale of a principal residence are fully exempt, as are gains from the sale of certain personal property worth less than $\$ 1,000$. Dividend income accruing to resident taxpayers from taxable Canadian corporations has been granted partial tax relief for several decades. This relief occurs through a gross-up and credit under the personal income tax. The gross-up and credit has been adjusted periodically with a view to maintaining rough parity in the tax treatment of small corporations and unincorporated businesses. Dividends are currently grossed-up by 25 percent and this grossed-up amount is taken into taxable income. The federal "basic tax" is then applied to personal income including grossed-up dividends, before the federal tax is reduced by a credit equal to 13.33 percent of the grossed-up dividend. When provincial taxes are taken into account, the net effect is to offset the double taxation of corporate source income accruing to individuals by roughly 50 percent for public companies and 100 percent for private corporations.

\section{B. April 1998 Report of the Technical Committee on Business Taxation}

8. The Committee reached a number of conclusions regarding the deficiencies of the current system of business taxes. First, combined federal-provincial corporate income tax rates, which average 43 percent, are higher than comparable rates in Canada's major trading partners. High corporate tax rates on non-manufacturing activities, in particular, tend to discourage business operations in Canada. Second, the relatively high variation in corporate tax rates across provinces and across industries exacerbate economic inefficiencies and unfairness, and increase compliance costs. Third, Canada's growing reliance on profit-insensitive business

\footnotetext{
${ }^{5}$ The province of Québec has its own separate pension plan that is roughly comparable to the CPP. Residents of Québec have the option of participating in either the CPP or the Québec Pension Plan.
}

${ }^{6} \mathrm{Lin}$, Picot, and Beach (1996) present a comprehensive review of developments in Canadian payroll taxes since 1961 . 
taxes (capital, property, payroll, sales, excise, and other non-profit business taxes) also exacerbate inequities and inefficiencies.

9. Broadly, the Committee recommends a number of steps to move closer to a neutral business tax system (one that does not alter investment or financing decisions), which would enhance efficiency, promote fairness, and improve competitiveness internationally. The Committee's recommendations include: (i) lowering corporate income tax rates toward international norms while broadening the tax base; (ii) altering certain profit-insensitive taxes so that these fall more heavily on those deriving associated benefits (the user pays principle); (iii) reducing compliance costs and improving tax enforcement; and (iv) enhancing the coordination and disentanglement of federal-provincial corporate tax policies.

10. By lowering the corporate income tax rate and broadening the base, overall tax-based disincentives to business activity could be reduced while also mitigating tax-induced distortions in resource allocation. The Committee notes that lowering the average federal-provincial corporate income tax rate to 33 percent for large businesses would be expected to ensure the system's international competitiveness. Thus, the Committee proposes that the general federal corporate income tax rate be reduced from 28 percent to 20 percent and that provincial corporate income taxes be reduced on average by 1 percentage point to 13 percent. Revenue neutrality would be maintained through the elimination of certain tax preferences, credits, and deductions. Preferences for small businesses would be retained, but with some modifications, including incentives for companies to increase employment.

11. The Committee also recommends that a closer correspondence be established between the level of certain profit-insensitive business taxes paid by firms and the economic benefits these firms receive from public goods or services, or the costs they impose on society (the user pays principle). Recommended measures include adopting experience-weighted employment insurance (EI) premiums for employers, under which employers with a history of fewer layoffs would pay lower EI premiums, and restructuring the federal fuel excise tax to include other pollutants in the tax base to ensure that the cost of environmentally damaging activities is borne, at least in part, by the responsible agent.

12. Measures recommended to enhance compliance and strengthen enforcement include: (i) harmonization of the structure and administration of certain federal and provincial business taxes-notably capital taxes; (ii) revised procedures for drafting tax legislation to enhance clarity; (iii) new mechanisms enabling Revenue Canada to apply sound commercial practices to settle disputes and collect assessed taxes; and (iv) provisions to expand civil penalties to include tax advisors and promoters of tax-related advice deemed to be grossly negligent.

13. In order to promote further tax cooperation and disentanglement between federal and provincial business tax policies, the Committee makes three principal recommendations. First, federal and provincial governments are encouraged to work toward using common, neutral corporate income and capital tax bases. Second, federal and provincial governments should extend the existing federal-provincial tax collection agreement to capital taxes, and to include 
all provinces. Finally, capital taxes should not be deductible from the corporate income tax base in order to eliminate an incentive for one level of government to expand its capital taxes. The provinces are also urged to enact an offsetting reduction in corporate income and capital taxes as base-broadening measures take affect. 


\section{List of References}

Department of Finance, 1998, Government of Canada: Tox Expenditures, (Ottawa).

Cole, Jeffrey and Michael Leidy, "Business Taxation in Canada," Canada-Selected Issues, International Monetary Fund, SM/97/3, January 15, 1997.

Lin, Zhengxi, Garnett Picot and Charles Beach, 1996, "The Evolution of Payroll Taxes in Canada," Working Paper No. 90, Statistics Canada (February).

Report of the Technical Committee on Business Taxation, (Ottawa) 1998. 


\section{THE CANADIAN PERSONAL INCOME TAX SYSTEM ${ }^{1}$}

1. The personal income tax system in Canada creates a number of disincentives to save and distorts the allocation of resources as a consequence of high marginal tax rates. The lack of full indexation of the personal income tax since 1986 has drawn individuals who were previously exempt from tax into the tax base, while it has pushed existing taxpayers into higher tax brackets. These problems could be addressed through a reduction in marginal tax rates and adjustments in nominal income thresholds (the income levels at which different tax rates apply), and standard credits. In addition, moving to full indexation of the personal income tax system would address the problem of bracket creep. Ameliorating the disincentives created by the personal income tax system, however, would likely be costly in terms of revenue foregone.

2. In Canada, personal income is taxed at both the federal and provincial levels. The federal income tax is progressive, with four marginal rates: $0,17,26$, and 29 percent. $^{2}$ The progressivity of the federal income tax is increased further by a system of refundable tax credits that provides assistance for low-income individuals and by surtaxes that rise with income. ${ }^{3}$ In some cases, credits are used instead of deductions to limit the tax relief to highincome earners.

3. From 1988 to 1998 , effective federal marginal rates rose as a result of increases in both the general surtax and the high-income surtax, while average federal tax rates also increased as a result of the shift from full to partial indexation in 1986. Over the period from the early 1980 s to 1994 , Davies (1998) reports that average federal income tax rates rose from about 10.4 percent in 1980 to nearly 14 percent in 1994 . Provincial income taxes are

'Prepared by Stephen Tokarick.

${ }^{2}$ For 1998 , federal income tax rates were 0 percent for income between $\$ 0-\$ 6,456,17$ percent for income between $\$ 6,456-\$ 29,590,26$ percent for income between $\$ 29,590-\$ 59,180$, and 29 percent on income over $\$ 59,180$. Effective July 1,1998 , a supplement of $\$ 500$ to the basic personal credit became available to low-income filers, which effectively eliminates the income tax on incomes up to $\$ 6,956$. The supplement is phased out at a rate of 4 percent of income in excess of $\$ 6,956$.

${ }^{3}$ Prior to July 1998, all individuals were subject to a 3 percent surtax. Effective July 1, 1998, the 3 percent surtax on incomes less than $\$ 50,000$ was eliminated, while it was reduced for those with incomes between $\$ 50,000$ and $\$ 65,000$. No reduction was granted for those with incomes above $\$ 65,000$ in order to focus tax relief on low- and middle-income earners. Also, an additional 5 percent surtax applies to individuals who owe $\$ 12,500$ or more in basic federal tax (those with incomes of approximately $\$ 65,000$ and above). 
generally calculated as a percentage of the basic federal tax plus any applicable surtaxes. ${ }^{4}$ Combining federal and provincial taxes for 1998, marginal tax rates were 25 percent for those with incomes between $\$ 7,000$ and $\$ 30,000,40$ percent for those with incomes between $\$ 30,000$ and $\$ 60,000$, and 51 percent for individuals with income in excess of $\$ 60,000$. Compared to U.S. tax rates, Canadian tax rates generally rise more quickly and the highest tax rate becomes applicable at a relatively low level of income. For example, the combined federal and average state marginal tax rate in the United States was only 32 percent for those with incomes between the Canadian dollar equivalent of $\$ 60,000$ to $\$ 95,000$. The highest combined marginal tax rate in the United States was 45 percent and did not become applicable until an individual reached an income level in excess of the equivalent of $\$ 430,000$ Canadian dollars.

4. Compared to other OECD countries, Canada's marginal income tax rates in 1995 were above the OECD average for middle- and high-income earners, while marginal rates for lowincome individuals were below the OECD average (OECD 1997). For example, an individual who earned 100 percent of the average production wage in 1995 faced a combined marginal tax rate of 45.9 percent, compared with the OECD average of 41.4 percent. An individual who earned 200 percent of the average production wage in 1995 faced a combined marginal tax rate of 48.1 percent, compared with the OECD average of 47.2 percent. Conversely, an individual who earned only 66 percent of the average production wage in 1995 faced a marginal tax rate of 31.4 percent, well below the OECD average of 37.9 percent.

5. The federal income tax system is indexed annually if the rate of inflation (as measured by the consumer price index) exceeds 3 percent. If inflation exceeds 3 percent, the excess of the rate over 3 percent is used to create index factors to adjust (increase) tax thresholds. Because inflation has remained below 3 percent since 1992, there have been no indexing adjustments to the tax system. As a consequence, individuals that were previously exempt from being taxed have been drawn into the tax base, and existing taxpayers have been pushed into higher tax brackets (bracket creep). The Department of Finance estimates that partial indexation since 1988 has drawn 1.3 million individuals into the tax base who would have been exempt if the system had been fully indexed, while another 2 million individuals were pushed from the 17 percent to the 26 percent tax bracket and another 562,000 people were pushed from the 26 percent to the 29 percent bracket. KPMG (1997) has calculated that for 1997 , the lack of full indexation costs an individual with taxable income between $\$ 35,941$ and $\$ 59,180$ an extra $\$ 1,210$ in taxes, and it costs an individual with taxable income in excess of $\$ 71,883$ an extra $\$ 1,782$.

${ }^{4}$ An exception is Québec, which administers its income tax separately from the federal tax. 
6. Recipients of income support through the Old-Age Security (OAS) and Guaranteed Income Support (GIS) system face serious disincentives to save as a result of tax-back rates. ${ }^{5}$ While GIS payments are not explicitly taxed, they are taxed implicitly because the amount of GIS benefits are reduced by 50 cents for each dollar of income in excess of the OAS/GIS minimum. Thus, recipients of GIS, who are in the lowest income groups, face a tax-back rate of 50 percent, which makes it unattractive to save for retirement. Middle- and high-income recipients do not face the high GIS tax-back rate, but face a disincentive to save as a consequence of the OAS tax-back rate of 15 percent.

7. The disincentives to save noted above are offset to some degree by provisions in the tax system that are designed to encourage saving, such as the deductibility of contributions to a registered retirement savings plan (RRSP) and the deferral of tax on interest income from this source. While this provision encourages savings to some extent, its effects are constrained by the fact that there are limits on the amounts that can be deducted from taxable income for retirement. ${ }^{6}$ Furthermore, these limits are frozen in nominal terms over the period from 1997 to 2004, which will erode the real value of this deduction. Also, these incentives are likely to be used by those with higher-than-average incomes, and so they do not mitigate the disincentives to save facing low- and middle-income savers. For this reason, these incentives may be perceived as inequitable.

8. The Department of Finance estimates that the costs of addressing the problems of the personal income tax system, principally through reductions in marginal tax rates and restoring full indexation, is substantial in terms of foregone revenue (Table 1). In 1999, the cost of reducing all marginal tax rates, the general 3 percent surtax, and the high-income 5 percent surtax by 1 percentage point is estimated to be about $\$ 4.2$ billion ( 0.5 percent of GDP), with about $\$ 0.4$ billion attributable to the cut in the general surtax, $\$ 0.1$ billion to the cut in the high-income surtax, and $\$ 3.7$ billion to the cut in all basic marginal rates. Restoring full indexation to the personal income tax would result in a revenue loss that grows from about $\$ 0.6$ billion in the first year to $\$ 2.4$ billion in the fourth year. The combined costs of reducing all marginal tax rates by 1 percentage point and restoring indexation (in the first year) are estimated to be $\$ 5$ billion, about 0.5 percent of GDP.

${ }^{5} \mathrm{OAS}$ pays benefits to Canadians age 65 and over, based on years of residence in Canada. Benefits are taxable and paid to all qualified individuals. GIS provides additional benefits to low-income seniors based on income and marital status.

${ }^{6}$ In 1997, individuals may deduct contributions to a registered retirement savings plan (RRSP) up to a limit (18 percent of income in 1996 or $\$ 13,500$ ) and these limits are frozen at $\$ 13,500$ until 2004 when the new limit will become $\$ 14,500$. In 2005 , the limit will rise to $\$ 15,500$ and be indexed thereafter to increases in the average industrial wage. 


\section{List of References}

Davies, James, 1998, "Marginal Tax Rates in Canada: High and Getting Higher," C.D. Howe Institute, Toronto.

Economic and Fiscal Update: Strong Economy and Secure Society, 1998, Department of Finance, Government of Canada.

KPMG, 1997, “The Tax Cost of Bracket Creep," Canadian Tax Notes, pp. 13-14.

OECD Economic Surveys: Canada, 1997, Organization for Economic Cooperation and Development. 


\section{Table 1. Fiscal Costs of Personal Income Tax Reductions}

(Full-year impact estimates for 1999)

Cost of Change

(\$ Million)

$\$ 100$ tax reduction for all taxpayers $1 /$

$\$ 100$ increase in amounts used to established selected credits

Basic personal amount 250

Married/equivalent-to-married amount

Federal surtaxes

Reduction by 1 percentage point of the general 3 percent surtax $2 /$

Reduction by 1 percentage point of high-income 5 percent surtax $3 /$

Reduction in marginal tax rates (per percentage point) 4 /

Lowest rate (17 percent)

Middle rate ( 26 percent)

High rate (29 percent)

1 percentage point reduction in each rate

Restoring indexation of tax parameters: $6 /$

Total impact:

Year 1

Year 2

Year 3

Year 4

Of which: Personal credits and tax brackets

Year 1

Year 2

Year 3

Year 4

Source: The Economic and Fiscal Update: Strong Economy and Secure Society, Department of Finance, 1998.

1/ Nonrefundable.

$2 /$ The general 3 percent surtax was eliminated for all taxpayers earning less than $\$ 50,000$ and reduced for those with incomes between $\$ 50,000$ and $\$ 65,000$ in the 1998 budget. The cost refers to the remainder of the surtax.

3/ Currently applies on basic federal tax in excess of $\$ 12,500$ on an income level of about $\$ 65,000.00$

4/ 17 percent rate applicable to taxable incomes up to $\$ 29,590 ; 26$ percent rate applicable to taxable incomes from $\$ 29,591$ to $\$ 59,180 ; 29$ percent rate applicable to taxable incomes from $\$ 59,181$ and up.

5/ Current credit value of base Canada Child Tax Benefit (CCTB) is $\$ 1,020$.

6/ Estimates assume 1.5 percent annual inflation. Impacts are cumulative. 


\section{V. "BRAIN DRAIN" FROM CANADA TO THE UNITED STATES'}

1. Available data indicate that emigration of highly skilled Canadian professionals to the United States increased substantially in the 1990s. This emigration of highly skilled individuals - "the brain drain"- -has potentially significant implications for the Canadian economy. While the flows of emigrants particularly in occupations such as physicians, nurses, engineers, and computer scientists has increased significantly, the size of the emigration flows has been small relative to the stock of existing workers in Canada who are employed in these occupations. At the same time, immigration of workers with similar skills has at least partially offset the number of emigrants to the United States. However, while no firm consensus exists on how the productivity of immigrants to Canada from the rest of the world compares with the productivity of Canadian-born workers, available evidence suggests that immigrants to Canada may be less productive because it takes some time for them to catch up with Canadian-born workers in terms of earnings. As a result, the loss of Canadian professionals to the United States is likely to have imposed a net cost on the Canadian economy.

2. One factor that may serve as an incentive for highly skilled individuals to emigrate from Canada to the United States is the relatively higher personal income tax burden in Canada compared to the United States, especially the burden applicable to the higher-income segment of the work force. A reduction in personal income tax rates could reduce the incentive for highly skilled Canadians to migrate to the United States.

\section{A. Data on the Size of Canadian Migration to the United States}

3. The average yearly flow of permanent skilled emigrants from Canada to the United States rose from about 3,100 in the period from 1982 to 1989 to 4,834 during the period from 1990 to 1996 (Table 1). ${ }^{2}$ Within this group of skilled workers, the average yearly flow of Canadian professionals who emigrated to the United States rose from 1,743 over 1982-89 to 2,689 over 1990-96, while the corresponding yearly averages were 985 and 1,756 for Canadian managerial workers. This increase in the average yearly gross flows of Canadian emigrants to the United States, coupled with the decline in the flows of U.S professional and managerial workers who emigrated to Canada during 1990-96, led to an increase in the net flows of professional workers from Canada to the United States. DeVoretz and Laryea (1998) argue that this increased emigration has been costly for Canada because emigrants embody education subsidies paid by Canadian taxpayers. The authors calculate that the net emigration of Canadians to the United States in four occupational categories (managers, natural scientists, professors and teachers, and professionals) resulted in an aggregate taxpayer

\section{${ }^{1}$ Prepared by Stephen Tokarick.}

${ }^{2}$ DeVoretz and Laryea (1998, p. 4) define a permanent migrant as someone who "has the intention of holding permanent employment." 
subsidy of \$651 million in 1993-94 (about 0.1 percent of GDP) from Canada to the United States. Concentrating on the occupational categories of professionals and managers, DeVoretz and Laryea (1998) estimate that the social cost of the emigration of these workers from Canada to the United States over the longer period from 1982 to 1996 amounted to $\$ 6.6$ billion ( 0.8 percent of GDP in 1996) and a net subsidy to the United States of $\$ 3.7$ billion (0.4 percent of Canada's GDP in 1996).

4. In addition to the significant increase in the number of permanent emigrants, there has also been a sharp rise in the number of temporary migrants from Canada to the United States since 1989. New visa categories have been created under U.S. immigration law as a result of both the Canada-U.S. Free Trade Agreement (FTA) in 1989 (the TC visa) and the North American Free Trade Agreement (NAFTA) in 1994 (the TN visa), which have greatly facilitated the movement of workers, especially professional workers, from Canada to the United States (Table 2). The main advantage of the TN visa is that it has reduced the cost of employing a temporary immigrant in the United States, as it is no longer necessary for the employer and the potential employee to prove that there will be no adverse effects on the employment of U.S. workers. The establishment of the TN visa status has become, as DeVoretz and Laryea (1998) note, a "backdoor to permanent emigration into the United States," because the rates of conversion from temporary to permanent status is high for some kinds of workers. For example, more than 37 percent of intracompany transfers between Canada and the United States in 1996 resulted in a switch from temporary visa status to permanent resident status.

5. Cast in the broader perspective of overall migration into and out of Canada, it can be argued that emigration of skilled workers to the United States may not have had a substantial impact on Canada. ${ }^{3}$ Data on overall migration indicate that losses of highly skilled individuals to the United States in a number of key professions have been more than offset by the inflow of skilled migrants from the rest of the world (Table 3). While Canadian emigrants to the United States outnumbered U.S. emigrants to Canada in every year over the period from 1986 to 1996 in the occupations of physicians, nurses, engineers, computer scientists, natural scientists, and managerial workers, net migration to Canada from countries other than the United States offset this net loss of emigrants to the United States in all of these occupations, except for physicians and nurses. These data also indicate that, although the number of Canadian emigrants to the United States has grown significantly in the last ten years, the size of the flows are relatively small in relation to the stock of skilled workers in key occupations (Table 4).

6. The argument that the brain drain from Canada to the United States is not a serious problem because any losses to the United States are offset by inflows from the rest of the world implicitly assumes that immigrants to Canada can substitute one for one with Canadian emigrants. DeVoretz and Laryea (1998) argue that immigrants impose "churning costs" on the

${ }^{3}$ Statistics Canada (1998). 
recipient country, relating to administrative and settlement costs of the immigrants, but more importantly, to costs that arise from the fact that immigrants may not be as productive as the emigrants that they replace. DeVoretz and Laryea (1998) note that the "entire post-1967 stock of professional immigrants typically took 10 to 15 years to catch up with the earnings of their Canadian-born cohorts." The difference in earnings between Canadian-born workers and non-U.S. immigrants may arise for a number of reasons, including language barriers. The data reported by Statistics Canada (1998) on the number of immigrants from countries other than the United States include individuals who declare themselves to have the appropriate qualifications for certain professions, but they may not be able to obtain the necessary certification to practice their professions in Canada. For these reasons, it may be misleading to conclude that immigrants from the rest of the world can replace Canadian emigrants on a onefor-one basis.

7. Taking into account the earnings gap between Canadian-born workers and non-U.S. immigrants to Canada, as well as administrative and settlement costs of new immigrants, DeVoretz and Laryea (1998) provide some estimates of the churning costs that arose from Canadian immigration during the period 1982-96. They estimated that the costs of replacing the outflow of highly skilled workers from Canada to the United States over this period amounted to $\$ 12.5$ billion (1.5 percent of GDP in 1996), with most of this cost ( $\$ 11.2$ billion, or 1.3 percent of GDP in 1996) occurring in the period 1989-96 when there was a significant increase in Canadian emigration to the United States.

\section{B. Incentives for Canadian Emigration to the United States}

8. On average, wages are higher in the United States than in Canada, and this provides one incentive for Canadian workers to emigrate. Moreover, given the higher wages in the United States, a significant public subsidy for higher education in Canada tends to provide a further incentive for emigration because the subsidy increases the supply of highly educated workers. The establishment of two temporary visa categories under the FTA and the NAFTA has lowered the costs of emigrating from Canada to the United States and has become an avenue for more permanent emigration.

9. Relatively high personal income taxes in Canada, compared to those in the United States, are also likely to be a significant incentive for emigration. The Canadian personal income tax becomes applicable at income levels that are lower than in the United States. ${ }^{4}$

${ }^{4}$ For example, a single-income tax payer in Canada can earn about $\$ 7,000$ and a taxpayer with two children can earn nearly $\$ 12,000$ before incurring any federal tax. No provincial tax would be applicable in these cases, since provincial taxes are calculated as a percentage of the basic federal tax. A single-income taxpayer in the United States can earn the equivalent of about $\$ 9,700$ in Canadian dollars before incurring federal tax, while a married couple with two 
Moreover, the highest marginal income tax rates in Canada become applicable at income levels that are much lower than in the United States. ${ }^{5}$ For an income level as low as $\$ 30,000$, the marginal income tax rate in Canada (federal and provincial) is about 40 percent, while in the United States, the typical marginal rate (federal and state) is about 26 percent. At income levels between $\$ 30,000$ and $\$ 95,000$ in Canadian dollars, the differential in marginal income tax rates between the two countries widens, as Canadian rates increase more steeply than U.S. rates. There has been a significant increase in the emigration of Canadian workers engaged in professional and skilled occupations to the United States in the 1990s, and the income of these occupational groups falls on average between $\$ 37,000$ and $\$ 90,000$. In some of these occupations, the average income exceeds $\$ 60,000$, and the tax differential between Canada and the United States is greatest for incomes between $\$ 60,000$ and $\$ 95,000$. Table 5 provides a comparison of the tax liabilities of individuals with various levels of income at certain locations in the United States and Canada to illustrate the combined effects of federal and provincial/state income taxes in the two countries.

10. Figures 1 and 2 present plots of the number of Canadian professional and managerial workers, respectively, who emigrated to the United States over the period from 1982-96. Both of these figures also include plots of two variables that may influence the decision to emigrate: the difference between the Canadian and the U.S. unemployment rates (defined as the Canadian rate minus the U.S. rate) and the difference between the ratio of personal income taxes to GDP in Canada (at the federal and provincial levels) and the United States (at the federal and state levels). As shown in both figures, the increase in the number of Canadian professional and managerial workers who emigrated to the United States over the period is clearly associated with a positive, and rising unemployment rate differential. Also, the difference between the personal income tax to GDP ratios widened over the period from 1989 to 1991, which coincided with the sharp increase in the number of Canadian skilled workers who emigrated to the United States. ${ }^{6}$

11. A number of changes were made to the personal income tax system in Canada between 1986 and 1991 that could help explain the rise in the personal income tax to GDP ratio in Canada relative to the United States. The income surtax on all taxpayers was increased to 3 percent in 1987, from 1.5 percent in 1986. This general surtax was increased to 4 percent in

\footnotetext{
${ }^{4}($...continued)
}

children can earn as much as $\$ 25,000$ in Canadian dollars free of federal tax. It should be noted however, that state tax laws vary, so it may be possible for an individual to be exempt from federal tax and liable for state tax.

${ }^{5}$ In Canada, the highest marginal income tax rates (federal and provincial) become applicable at an income level of about $\$ 60,000$, while in the United States, the highest federal and state rates kick in at an income level of about $\$ 430,000$ in Canadian dollars.

${ }^{6}$ The differential increased from about 2.5 percent in 1989 to 4.5 percent in 1991. 
1989 , and to 5 percent in 1990. In 1989, an additional high-income surtax of 1.5 percent was introduced and subsequently raised to 5 percent in December 1991, bringing the total surtax to 10 percent for individuals in the top tax bracket. The income threshold at which the highincome surtax became applicable was also lowered in 1991. In 1986, full indexation of the personal income tax system was replaced by partial indexation, which drew individuals who were previously exempt from taxation into the tax base and pushed others into higher tax brackets.'

12. Since 1991, the difference between the personal income tax to GDP ratios in Canada and the United States narrowed, but remained positive, mainly on account of tax increases in the United States that became effective in 1993. ${ }^{8}$ The gap also narrowed because the personal income tax to GDP ratio declined in Canada between 1991 and 1994, mainly as a result of reductions in the general income surtax (from 5 percent in 1991 to 3 percent in 1993), but the tax ratio rose again between 1994 and 1996 on account of "bracket creep" resulting from the lack of indexation in Canada. Despite the narrowing in the personal income tax differentials between Canada and the United States in 1991-96, emigration of skilled workers from Canada to the United States continued to rise. A number of factors could serve to explain this development, including differences in real wages between the United States and Canada and the differential unemployment rate.

13. Table 6 contains the results from pooling the number of Canadian professional (PROF) and managerial (MANG) emigrants into a total emigrant group (EMIG), and regressing this group on the differential unemployment rates (DIFFUR) and the differential personal income tax to GDP ratios (DIFFTAX). This regression allows the coefficient on DIFFUR to vary by type of emigrant (PROF and MANG), but imposes a common coefficient on DIFFTAX. The results reveal that the coefficients on DIFFUR are of the expected sign, significant at the 1 percent level for professional emigrants, and significant at the 3 percent level for managerial emigrants. The coefficient on DIFFTAX is of the expected sign and significant at the 1 percent level. It should be noted that these results merely suggest that DIFFUR and DIFFTAX are positively correlated with the number of Canadian professional and managerial emigrants to the United States and that these variables may be important factors in explaining the rise in emigration since 1989. Still, this regression omits a number of other factors that are likely to be relevant in explaining the movement of skilled workers from Canada to the United States, some of which cannot be quantified.

${ }^{7}$ Indexing adjustments are made when the inflation rate exceeds 3 percent.

${ }^{8}$ The differential declined from 4.5 percent in 1991 to 3 percent in 1996. 


\section{List of References}

Brown, Robert, 1997, "Tax Impacts on People Transfers: Notes and Tables," C.D. Howe Institute, Toronto.

Globerman, Steven, and Don DeVoretz, 1998, "Trade Liberalization and the Migration of Skilled Workers," Simon Fraser University.

DeVoretz, Don, and Samuel Laryea, 1998, "Canadian Human Capital Transfers: The United States and Beyond," C.D. Howe Institute, Toronto.

Statistics Canada 1998, "Brain Drain or Brain Gain? What Do the Data Say?, slides and speaking notes. 
Table 1. Canada: Bilateral Immigration Flows by Occupational Group, 1982-96

\begin{tabular}{|c|c|c|c|c|c|c|c|c|c|c|c|c|}
\hline & \multicolumn{2}{|c|}{$1982-89$} & \multirow[b]{2}{*}{1990} & \multirow[b]{2}{*}{1991} & \multirow[b]{2}{*}{1992} & \multirow[b]{2}{*}{1993} & \multirow[b]{2}{*}{1994} & \multirow[b]{2}{*}{1995} & \multirow[b]{2}{*}{1996} & \multicolumn{2}{|c|}{$1990-96$} & \multirow[b]{2}{*}{$\begin{array}{c}\text { Total } \\
1982-96 \\
\end{array}$} \\
\hline & $\begin{array}{l}\text { Total } \\
\text { Flow } \\
\end{array}$ & $\begin{array}{r}\text { Yearly } \\
\text { Average } \\
\end{array}$ & & & & & & & & $\begin{array}{l}\text { Total } \\
\text { Flow } \\
\end{array}$ & $\begin{array}{r}\text { Yearly } \\
\text { Average } \\
\end{array}$ & \\
\hline \multicolumn{13}{|l|}{ Total Canadian flows to } \\
\hline the United States & 24,774 & 3,097 & 4,996 & 3,946 & 4,559 & 5,256 & 5,052 & 4,031 & 5,997 & 33,837 & 4,834 & 58,611 \\
\hline Professionals $1 /$ & 13,940 & 1,743 & 2,493 & 2,080 & 2,384 & 2,916 & 2,929 & 2,440 & 3,581 & 18,823 & 2,689 & 32,763 \\
\hline Managers & 7,883 & 985 & 1,751 & 1,327 & 1,853 & 2,022 & 1,861 & 1,415 & 2,065 & 12,294 & 1,756 & 20,177 \\
\hline Other skilled 2/ & 2,951 & 369 & 752 & 539 & 322 & 318 & 262 & 176 & 351 & 2,720 & 389 & 5,671 \\
\hline Total U.S. nows to Canada & 13,774 & 1,722 & n.a. & 1,367 & 1,489 & 1,516 & 1,374 & 1,080 & 993 & 7,819 & 1,117 & 21,593 \\
\hline Professionals $1 /$ & 8,176 & 1,022 & n.a. & 834 & 980 & 999 & 877 & 676 & 641 & 5,007 & 715 & 13,183 \\
\hline Managers & 3,783 & 473 & n.a. & 351 & 360 & 370 & 374 & 332 & 302 & 2,089 & 298 & 5,872 \\
\hline Other skilled 2/ & 1,815 & 227 & n.a. & 182 & 149 & 147 & 123 & 72 & 50 & 723 & 103 & 2,538 \\
\hline Net flows & 11,000 & 1,375 & n.a. & 2,579 & 3,070 & 3,740 & 3,678 & 2,951 & 5,004 & 26,018 & 3,717 & 37,018 \\
\hline Professionals 1/ & 5,764 & 721 & n.a. & 1,246 & 1,404 & 1,917 & 2,052 & 1,764 & 2,940 & 13,816 & 1,974 & 19,580 \\
\hline Managers & 4,100 & 513 & n.a. & 976 & 1,493 & 1,652 & 1,487 & 1,083 & 1,763 & 10,205 & 1,458 & 14,305 \\
\hline Other skilled $2 /$ & 1,136 & 142 & n.a. & 357 & 173 & 171 & 139 & 104 & 301 & 1,997 & 285 & 3,133 \\
\hline
\end{tabular}

Sources: Data are reported in Devoetz and Laryea (1998). Data on Canadian emigration to the United States are taken from the U.S. Department of Immigration and Naturalization. Data on U.S. emigration to Canada are taken from the Canadian Department of Immigration and Naturalization.

$1 /$ Includes professionals in the natural and social sciences, teaching, medicine and health, and the performing arts.

$2 /$ Includes workers in precision production, machining, crafts, and repair and construction occupations. 
Table 2. Canada: Flows of Canadian Non-Immigrant Professionals and Their Families to the United States Under FTA and NAFTA, 1989-96

\begin{tabular}{|c|c|c|c|c|c|c|c|c|}
\hline & 1989 & 1990 & 1991 & 1992 & 1993 & 1994 & 1995 & 1996 \\
\hline Professional workers under FTA (TC Visa) & 2,677 & 5,293 & 8,123 & 12,531 & 16,610 & & & \\
\hline Percent change & & 97.7 & 53.5 & 54.3 & 32.6 & & & \\
\hline Spouses and children & 140 & 594 & 777 & 1,271 & 2,386 & & & \\
\hline Percent change & & 324.3 & 30.8 & 63.6 & 87.7 & & & \\
\hline Professional workers under NAFTA (TN Visa) & & & & & & 19,806 & 23,904 & 26,987 \\
\hline Percent change & & & & & & & 20.7 & 12.9 \\
\hline Spouses and children & & & & & & 5,535 & 7,202 & 7,694 \\
\hline Percent change & & & & & & & 30.1 & 6.8 \\
\hline
\end{tabular}

Source: DeVoretz (1998). Data are originally taken from United States Department of Justice, Immigration and Naturalization Service, Statistical Yearbook of the Immigration and Naturalization Service (Washington, D.C.: Immigration and Naturalization Service, Office of Policy Planning, Statistics Branch), various years. 
Table 3. Canada: Net and Gross Immigration Flows for Selected Occupations, 1986-96

1986

1987

1988

1989

1990

1991

1992

1993

1994

1995

1996

\section{Physicians}

Canadian flows to the United States

U.S. flows to Canada

Net bilateral balance $1 /$

Immigration from rest of world

to Canada

Total net flows

$\begin{array}{rr}153 & 131 \\ 23 & 22 \\ -130 & -109 \\ 419 & 427 \\ 289 & 318\end{array}$

\section{Nurses}

Canadian flows to the United States

U.S. flows to Canada

Net bilateral balance 1/

Immigration from rest of world

to Canada

Total net flows

\section{Engineers}

Canadian flows to the United States

U.S. flows to Canada

Net bilateral balance 1/

Immigration from rest of world

to Canada

Total net flows

Computer scientists

Canadian flows to the United States

U.S. flows to Canada

Net bilateral balance 1/

Immigration from rest of world

to Canada

Total net flows

$\begin{array}{rrrrrrrrr}88 & 149 & 149 & 203 & 264 & 325 & 321 & 365 & 522 \\ 17 & 22 & 16 & 25 & 20 & 29 & 16 & 16 & 7 \\ -71 & -127 & -133 & -178 & -244 & -296 & -305 & -349 & -515 \\ 339 & 460 & 450 & 489 & 464 & 529 & 358 & 335 & 342 \\ 268 & 333 & 317 & 311 & 220 & 233 & 53 & -14 & -173\end{array}$

$\begin{array}{rrrrrrrrrrr}362 & 381 & 294 & 285 & 373 & 531 & 755 & 993 & 1,058 & 897 & 1,104 \\ 104 & 109 & 111 & 90 & 87 & 78 & 69 & 58 & 30 & 31 & 28 \\ -258 & -272 & -183 & -195 & -286 & -453 & -686 & -935 & -1,028 & -866 & -1,076 \\ & & & & & & & & & & \\ 393 & 739 & 1,049 & 1,188 & 1,270 & 1,163 & 1,012 & 872 & 827 & 634 & 421 \\ 135 & 467 & 866 & 993 & 984 & 710 & 326 & -63 & -201 & -232 & -655\end{array}$

$\begin{array}{rrrrrrrrrrr}518 & 508 & 319 & 433 & 524 & 541 & 685 & 567 & 447 & 422 & 506 \\ 60 & 72 & 48 & 56 & 52 & 72 & 77 & 85 & 76 & 78 & 93 \\ -458 & -436 & -271 & -377 & -472 & -469 & -608 & -482 & -371 & -344 & -413 \\ & & & & & & & & & & \\ 1,005 & 1,881 & 1,881 & 2,207 & 2,544 & 2,357 & 2,318 & 3,736 & 4,719 & 6,195 & 8,278 \\ 547 & 1,445 & 1,610 & 1,830 & 2,072 & 1,888 & 1,710 & 3,254 & 4,348 & 5,851 & 7,865\end{array}$

$\begin{array}{rrrrrrrrrrr}91 & 101 & 88 & 127 & 120 & 127 & 161 & 148 & 153 & 116 & 148 \\ 65 & 73 & 53 & 61 & 38 & 63 & 82 & 92 & 102 & 118 & 113 \\ -26 & -28 & -35 & -66 & -82 & -64 & -79 & -56 & -51 & 2 & -35 \\ & & & & & & & & & & \\ 493 & 1,184 & 1,151 & 895 & 1,094 & 1,272 & 1,698 & 2,921 & 3,610 & 4,887 & 6,467 \\ 467 & 1,156 & 1,116 & 829 & 1,012 & 1,208 & 1,619 & 2,865 & 3,559 & 4,889 & 6,432\end{array}$


Table 3. Canada: Net and Gross Immigration Flows for Selected Occupations, 1986-96 (Concluded)

\begin{tabular}{|c|c|c|c|c|c|c|c|c|c|c|c|}
\hline & 1986 & 1987 & 1988 & 1989 & 1990 & 1991 & 1992 & 1993 & 1994 & 1995 & 1996 \\
\hline \multicolumn{12}{|l|}{ Natural scientists } \\
\hline Canadian flows to the United States & 94 & 115 & 87 & 74 & 112 & 111 & 140 & 197 & 137 & 114 & 195 \\
\hline U.S. flows to Canada & 49 & 43 & 33 & 46 & 45 & 47 & 54 & 53 & 67 & 63 & 61 \\
\hline Net bilateral balance $1 /$ & 45 & -72 & -54 & -28 & -67 & -64 & -86 & -144 & -70 & -51 & -134 \\
\hline \multicolumn{11}{|l|}{ Immigration from rest of world } & 2,794 \\
\hline Total net flows & 319 & 477 & 544 & 745 & 717 & 715 & 537 & 626 & 1,265 & 1,883 & 2,660 \\
\hline \multicolumn{12}{|l|}{ Managerial workers } \\
\hline Canadian flows to the United States & 1,490 & 1,679 & 1,185 & 1,571 & 1,620 & 1,773 & 2,829 & 2,882 & 2,607 & 2,060 & 2,659 \\
\hline U.S. flows to Canada & 538 & 615 & 498 & 524 & 388 & 384 & 415 & 424 & 425 & 370 & 355 \\
\hline $\begin{array}{l}\text { Net bilateral balance } 1 / \\
\text { Immigration from rest of world }\end{array}$ & -952 & $-1,064$ & -687 & $-1,047$ & $-1,232$ & $-1,389$ & $-2,414$ & $-2,458$ & $-2,182$ & $-1,690$ & $-2,304$ \\
\hline to Canada & 3,984 & 8,514 & 10,453 & 11,027 & 11,193 & 8,494 & 10,710 & 11,740 & 11,452 & 10,630 & 13,508 \\
\hline Net outflows from Canada & 3,032 & 7,450 & 9,766 & 9,980 & 9,961 & 7,105 & 8,296 & 9,282 & 9,270 & 8,940 & 11,204 \\
\hline
\end{tabular}

Source: Data are taken from Statistics Canada (1998).

$1 /$ A minus (-) sign denotes a deficit for Canada. 
Table 4. Canadian Emigration to the United States For Selected Occupations

\begin{tabular}{lcrr}
\hline & $\begin{array}{r}\text { Annual Average } \\
\text { Emigration to } \\
\text { the United States } \\
(1990-96)\end{array}$ & $\begin{array}{r}\text { Total Stock of } \\
\text { Workers in the } \\
\text { Canadian Labor } \\
\text { Force (1996) }\end{array}$ & $\begin{array}{r}\text { Emigration } \\
\text { as a Fraction } \\
\text { of the Stock }\end{array}$ \\
\hline Physicians & 307 & 59,340 & $5 / 1000$ \\
Nurses & 816 & 246,800 & $3 / 1000$ \\
Computer scientists & 139 & 168,385 & $1 / 1000$ \\
Engineers & 527 & 172,415 & $3 / 1000$ \\
Managerial workers & 2,347 & $1,927,760$ & $1 / 1000$ \\
\hline
\end{tabular}

Source: Statistics Canada (1998). 
Table 5. Canada: Comparison of Personal Income Tax Liabilities Between Canada and the United States, 1997

(All values are in U.S. dollars)

\begin{tabular}{|c|c|c|c|c|}
\hline \multirow[b]{2}{*}{ Tax Category } & \multicolumn{4}{|c|}{ Tax Liabilities } \\
\hline & New York City $1 /$ & Houston $1 /$ & Toronto $2 /$ & Calgary 21 \\
\hline \multicolumn{5}{|l|}{$\begin{array}{l}\text { 1. Single person } \\
\text { Rents }\end{array}$} \\
\hline Income $=\$ 25,000$ & 6,200 & 4,600 & 6,100 & 6,100 \\
\hline \multicolumn{5}{|l|}{$\begin{array}{l}\text { 2. Single person } \\
\text { Rents }\end{array}$} \\
\hline Income $=\$ 60,000$ & 21,300 & 16,300 & 21,900 & 21,100 \\
\hline \multicolumn{5}{|l|}{$\begin{array}{l}\text { 3. Married, nonworking spouse } \\
\text { Two children } \\
\text { Owns home with mortgage }\end{array}$} \\
\hline Income $=\$ 60,000$ & 14,000 & 10,400 & 20,700 & 20,000 \\
\hline \multicolumn{5}{|l|}{$\begin{array}{l}\text { 4. Married, nonworking spouse } \\
\text { Two children } \\
\text { Owns home with mortgage }\end{array}$} \\
\hline Income $=\$ 100,000$ & 27,200 & 21,100 & 41,300 & 38,500 \\
\hline \multicolumn{5}{|l|}{$\begin{array}{l}\text { 5. Married, with working spouse } \\
\text { Two children } \\
\text { Owns home with mortgage }\end{array}$} \\
\hline Income $=\$ 100,000$ & 29,300 & 23,200 & 33,500 & 32,900 \\
\hline \multicolumn{5}{|l|}{$\begin{array}{l}\text { 6. Married, nonworking spouse } \\
\text { Two children } \\
\text { Owns home with mortgage }\end{array}$} \\
\hline \multicolumn{5}{|l|}{$\begin{array}{l}\text { 7. Married, nonworking spouse } \\
\text { Two children } \\
\text { Owns home with mortgage }\end{array}$} \\
\hline Income $=\$ 500,000$ & 178,000 & 161,800 & 246,700 & 222,700 \\
\hline
\end{tabular}

Source: Robert Brown, "Tax Impacts on People Transfers: Notes and Tables to Illustrate a Talk," C.D. Howe Institute, 1997.

1/ U.S. taxes include federal, state, and social security taxes.

2/ Canadian taxes include federal, provincial, and CPP taxes. 
Table 6. Canada: Regression Results for Professional and Managerial Emigrants from Canada to the United States

Results for Pooled Regression:
$\mathrm{EMIG}=98.8+464.0 \cdot \mathrm{DIFFUR}-\mathrm{-PROF}+214.0 \cdot \mathrm{DIFFUR}-\mathrm{MANG}+207.6 \cdot \mathrm{DIFFTAX}$ (285.6) (88.1)* $(87.9)^{* * *}$ $(62.9)^{*}$

$R^{2}=0.79$, Durbin-Watson $=1.84$, F-statistic $=21.5$

Notes:

1. EMIG = pooled sample of Canadian professional and managerial emigrants.

2. PROF = number of professional Canadian emigrants to the United States.

3. MANG = number of managerial Canadian emigrants to the United States.

4. DIFFUR = Canadian unemployment rate - U.S. unemployment rate.

5. DIFFTAX = Ratio of personal income taxes (at federal and provincial levels) to GDP in Canada minus the ratio of personal income taxes (at the federal and state levels) in the United States.

6. Equations are estimated over the period from 1982-1996 using annual data.

7. Standard errors of the coefficients are reported in parenthesis.

* Significant at the 1 percent level.

** Significant at the 3 percent level. 
FIGURE 1

CANADA

PROFESSIONAL EMIGRANTS FROM CANADA TO THE UNITED STATES

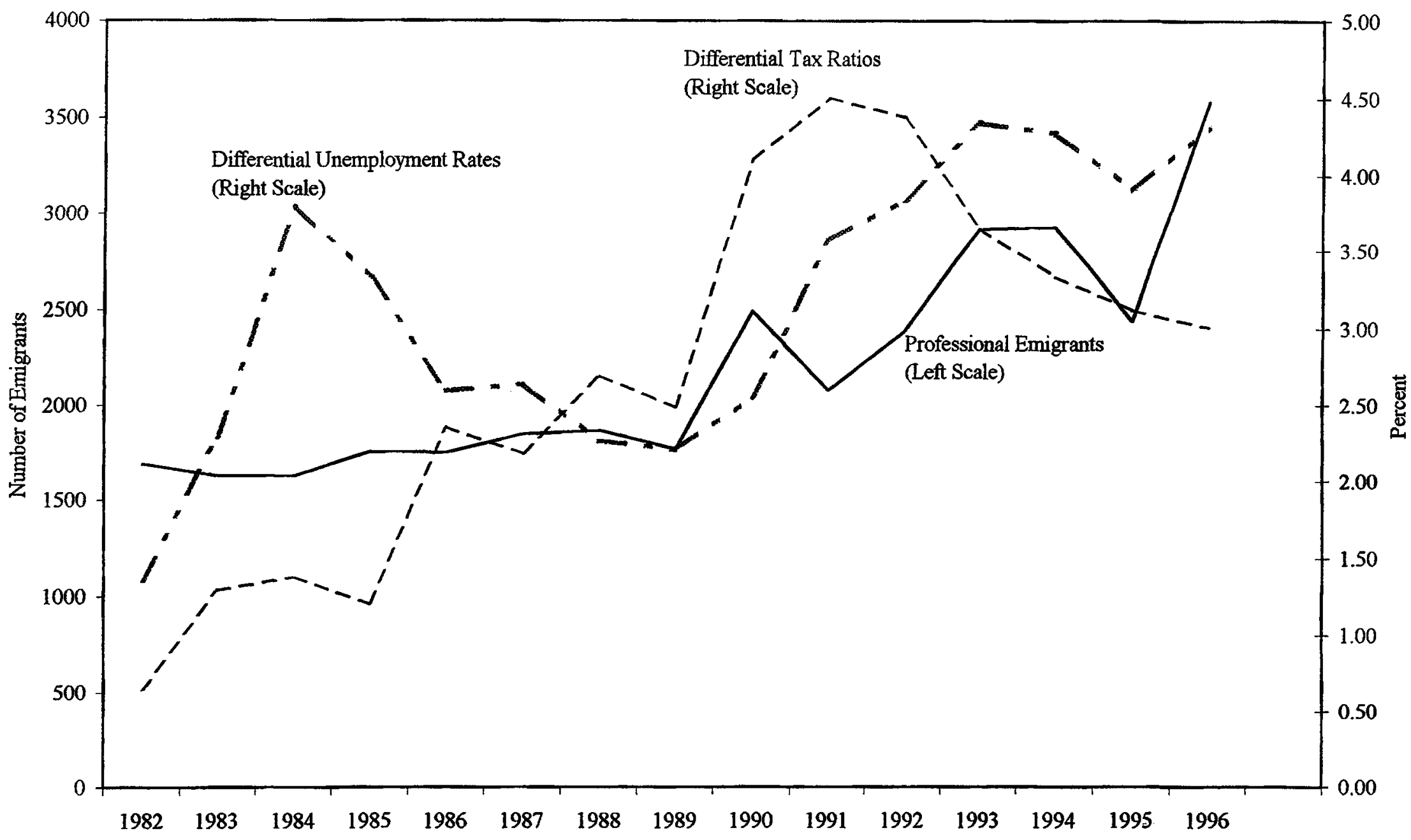

Sources: DeVoretz and Laryea (1998); Statistics Canada; Department of Finance, Government of Canada; Economic Report of the President, 1998; and U.S. Bureau of the Census. 
FIGURE 2

CANADA

MANAGERIAL EMIGRANTS FROM CANADA TO THE UNITED STATES

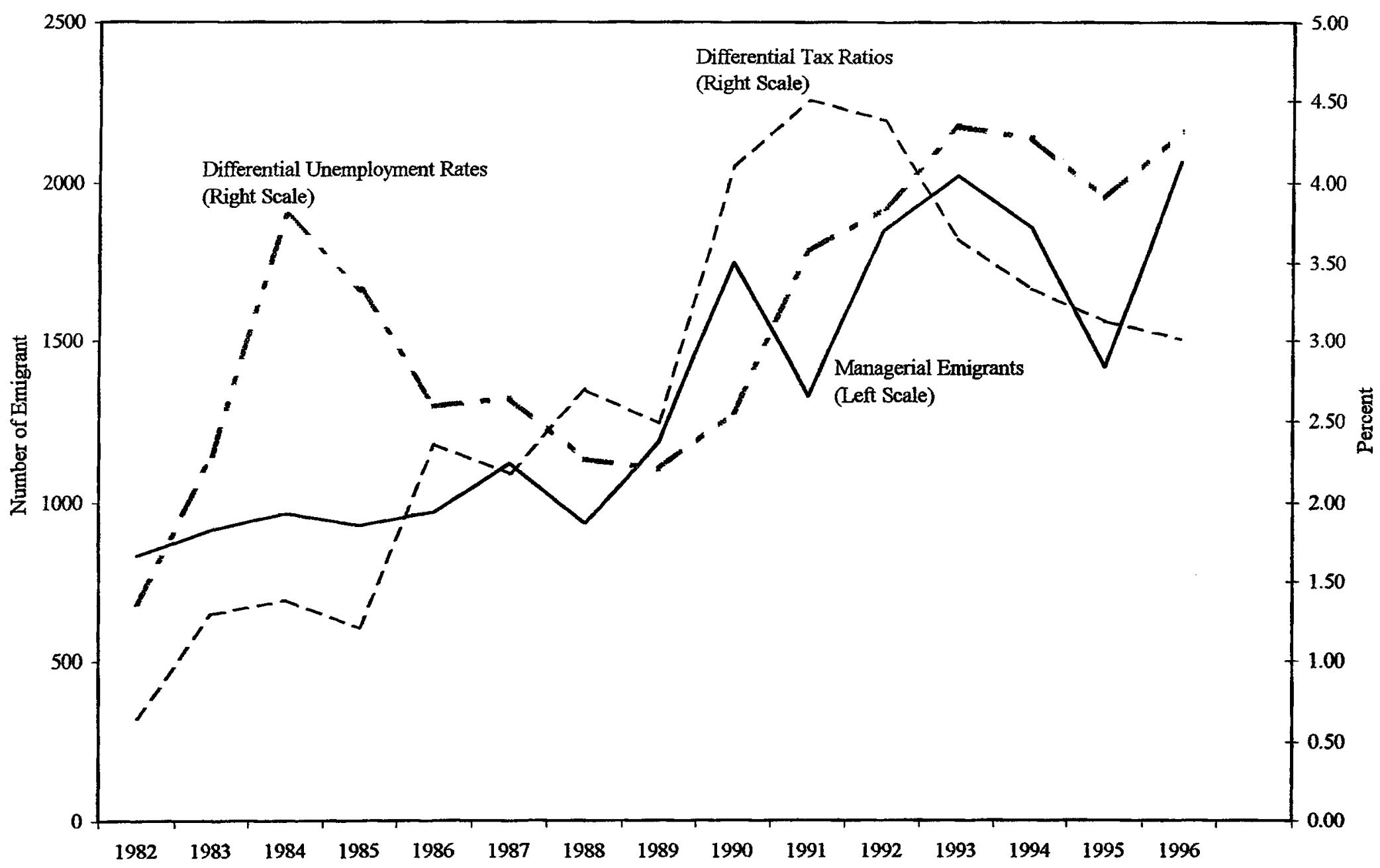

Sources: DeVoretz and Laryea (1998); Statistics Canada; Department of Finance, Government of Canada; Economic Report of the President, 1998; and U.S. Bureau of the Census. 


\section{POVERTY TRAPS AND SOCIAL ASSISTANCE REFORM IN CANADA ${ }^{1}$}

1. Macroeconomic and structural policy changes, exogenous world events (such as commodity price shocks), and the ordinary functioning of dynamic market economies can cause dislocation in labor markets. Policies intended to ease the burden of adjusting to such dislocation help to maintain social and economic stability. Such programs, however, if not well designed, may introduce incentives to withdraw from the labor force and present hurdles to labor-force re-entry, and thus may create "poverty traps." From the early 1980 s through the mid-1990s, participation in social assistance programs across Canada trended upward. Facing rising welfare rolls and substantial fiscal pressures, most Canadian provinces have recently initiated or completed significant reforms of their social assistance systems. This paper reviews recent developments in social assistance (welfare) programs across Canada with a view to evaluating the scope, extent, and province-specific nature of the poverty trap problem. ${ }^{2}$

\section{A. National and Provincial Developments in Income Support Statistics}

2. The share of the Canadian population on social assistance increased from about $51 / 2$ percent at the beginning of the 1980 s to a peak of $10 \frac{1}{2}$ percent in 1994 , before declining to just over 9 percent in 1997 (Table 1 and Figure 1). During the recession years of 1981-82 and 1990-92, the share increased without returning to pre-recession levels in the ensuing years of economic expansion. Although many of the provinces exhibited a similar pattern, the growth of welfare populations varied significantly across provinces. The most dramatic increase occurred in Ontario, where beneficiaries as a share of the population tripled from the early 1980s to their peak in 1994 . Over roughly the same period, the ratio doubled in British Columbia and Alberta, increased by around 80 percent in Manitoba, Nova Scotia, and Saskatchewan, and rose by about 40 percent from already high levels in Québec and Newfoundland.

3. After rising by about 30 percent during the 1970 s, real social assistance outlays per capita across Canada rose by about 45 percent during the 1980s, before skyrocketing another 70 percent from 1990 to 1994 (Table 2 and Figure 2). Beginning in the 1980s, these increases significantly outpaced the growth rate of real per capita personal income, illustrating the sharply growing burden of social assistance spending on the general population (Figure 3). Real benefits per recipient also increased during the 1970s, 1980s, and the first half of the 1990s (Figure 4), rising by about 20 percent during the 1980s and by another 10 percent over the period 1990-94, compared with real per capita personal income growth of about

\footnotetext{
${ }^{1}$ Prepared by Paula De Masi and Michael Leidy.
}

${ }^{2}$ The focus of the paper is on poverty traps generated by social assistance, and therefore employment insurance, disability insurance, old-age income support programs, and social assistance for the disabled are excluded from the discussion. 
18 percent and negative 4 percent during these respective periods. Reforms implemented in the past few years at both the federal and provincial levels have brought overall expenditures down by about 20 percent from their 1994 peak. However, the reductions in spending vary considerably across the individual provinces.

4. The percentage of long-term welfare recipients also increased during the 1990s. In March 1990, 41 percent of all welfare recipients had been receiving benefits for 25 consecutive months or longer (defined as "long-term" recipients). As the welfare population rose in the recession years of 1990-92, the influx of new recipients initially reduced the share of longterm recipients to 32 percent by March 1992 (Table 3). However, the share of long-term recipients rose steadily through March 1997, when it reached 50 percent.

5. The real value of social assistance benefits by recipient type rose from the mid-1980s to the early 1990s in Québec, Ontario, and British Columbia, but remained roughly constant, or fell slightly, in the other provinces (Table 4). For single parents and couples with two children, many provinces offered benefits in 1993 that were at or above two-thirds of the average manufacturing wage of full-time workers. Since 1993-94, however, real social assistance benefits have tended to fall across Canada, with relatively steep cuts occurring in Prince Edward Island, Québec, Ontario, Manitoba, and Alberta.

\section{B. Federal and Provincial Roles in Poverty Programs}

6. Since adoption of the 1966 Canada Assistance Plan (CAP), the federal government's role in social assistance has been largely confined to establishing basic national standards and providing transfers to the provinces. ${ }^{3}$ The specific design, and the associated incentive structure of assistance programs, has been largely the responsibility of the provinces, resulting in a wide variety of rules and regulations. In recent years, the federal government has exerted indirect influence over the structure of these programs through restrictions on federal financing. The systemic decline in real benefits across Canada that has taken place over the past several years was influenced by the restraint in the growth of federal transfers for social assistance exercised in the early 1990s and strengthened under the Canada Health and Social Transfer (CHST) ${ }^{4}$ More recently, the federal government has been working with the provincial governments to develop a set of shared principles and objectives to underlie social programs in Canada.

\footnotetext{
${ }^{3}$ Under the CAP, the federal government finances half of the total value of provincial outlays for social assistance, provided provincial programs meet certain national standards.

${ }^{4}$ Beginning in fiscal year 1996/97, the federal government's contribution to provincial health and social programs (including post-secondary education) was consolidated in a single block transfer, the CHST.
} 
7. The National Child Benefit (NCB) is another significant piece of the social safety net in Canada. Launched in July 1998, the NCB is a cooperative initiative by the federal and provincial governments that seeks to mitigate the poverty trap problem by providing payments to all low- and moderate-income families with children regardless of their sources of income. This federal transfer replaces separate systems of child benefits and working income supplements in the various provinces (with the exception of Québec) with an integrated system that does not discriminate against those entering the labor force. Corresponding to this new federal benefit, the provinces have agreed to reduce social assistance payments to families with children by the amount of the NCB and to allocate the freed-up funds to complementary programs that will improve work incentives and benefits for all low-income families with children, rather than just those on social assistance. ${ }^{5}$

\section{Incentive Effects of Income Support Programs}

8. Although the trend toward increased welfare participation in Canada likely has multiple causes (including reduced employment opportunities for poorly educated individuals, and a rise in the number of single-parent families), the role of financial disincentives to work, and thus to terminate reliance on social assistance-poverty traps-should not be understated. The poverty traps problem can be decomposed into two elements. The first is the extent to which the system of income support tends to draw people out of the labor force and onto government assistance rolls. The second is the extent to which the system of income support tends to discourage existing recipients from re-entering the labor force. The level of benefits relative to average wages for unskilled workers, the restrictiveness of eligibility rules and their enforcement, and the extent, if any, of social stigma attached to welfare, are among the features of a social assistance program that determine the tendency to attract participants. Once in the system, effective marginal income tax rates, determined in large part by the withdrawal of benefits upon entry into the labor force (but also by payroll taxes and federal and provincial income tax rates), can strongly discourage labor market participation. For example, a social assistance beneficiary moving into the workforce to earn $\$ 600$ a month in labor income could face an effective marginal income tax rate in excess of 80 percent (tabulation below). Also, time limits on the duration of benefits and education and training opportunities all help to determine the extent to which existing welfare recipients might be discouraged from working. However, if social assistance recipients are allowed to retain some benefits after re-entering the labor force, effective marginal tax rates can be reduced, but lowwage workers that have migrated through social assistance to work may be financially better

${ }^{5}$ See, for example, the summary of provincial benefits for families with children in Clark (1998). Under the NCB, provinces are expected to implement new programs for all lowincome families with children including one or more of the following: (i) income support programs; (ii) earned income supplements; (iii) child support supplements; (iv) extension of in-kind benefits now available to social assistance recipients to all low-income families; (v) tax measures; and (vi) other social services, such as child care. 
off than those who have never accepted social assistance benefits (tabulation below). This condition may create a "revolving door" through social assistance. The specific design of social assistance programs can exacerbate or mitigate all of these conditions to varying degrees.

\begin{tabular}{|c|c|c|c|c|c|c|c|c|c|c|c|c|}
\hline \multicolumn{13}{|c|}{$\begin{array}{c}\text { Marginal Income Tax Rates for Social Assistance Recipients, } \\
\text { Earning } \$ 600 \text { per Month from Employment } 1 /\end{array}$} \\
\hline & Jan. & Feb. & Mar. & Apr. & May & June & July & Aug. & Sept. & Oct. & Nov. & Dec. \\
\hline Eamed income (in dollars) & 600 & 1,200 & 1,800 & 2,400 & 3,000 & 3,600 & 4,200 & 4,800 & 5,400 & 6,000 & 6,600 & 7,200 \\
\hline $\begin{array}{l}\text { Applicable payroll and federal tax } \\
\text { rates (in percent): } \\
\text { Canada Pension Plan tax } 2 / \\
\text { Employment Insurance tax } 3 / \\
\text { Personal income tax } 4 /\end{array}$ & $\begin{array}{r}0 \\
2.7 \\
0\end{array}$ & $\begin{array}{r}0 \\
2.7 \\
0\end{array}$ & $\begin{array}{r}0 \\
2.7 \\
0\end{array}$ & $\begin{array}{r}0 \\
2.7 \\
0\end{array}$ & $\begin{array}{r}0 \\
2.7 \\
0\end{array}$ & $\begin{array}{r}3.2 \\
2.7 \\
0\end{array}$ & $\begin{array}{r}3.2 \\
2.7 \\
0\end{array}$ & $\begin{array}{r}3.2 \\
2.7 \\
0\end{array}$ & $\begin{array}{r}3.2 \\
2.7 \\
0\end{array}$ & $\begin{array}{r}3.2 \\
2.7 \\
0\end{array}$ & $\begin{array}{r}3.2 \\
2.7 \\
0\end{array}$ & $\begin{array}{r}3.2 \\
2.7 \\
17\end{array}$ \\
\hline $\begin{array}{l}\text { Cumulative eamed income } \\
\text { net of taxes (in dollars) }\end{array}$ & 584 & 1,168 & 1,751 & 2,335 & 2,919 & 3,500 & 4,064 & 4,629 & 5,193 & 5,758 & 6,323 & 6,846 \\
\hline $\begin{array}{l}\text { Cumulative income exemption } \\
\text { (in dollars) } \\
\text { Clawback rate after income } \\
\text { exemption (in percent) } 5 /\end{array}$ & $\begin{array}{r}100 \\
80\end{array}$ & $\begin{array}{r}200 \\
80\end{array}$ & 300 & 400 & 500 & 600 & 700 & 800 & 900 & $\begin{array}{r}1,000 \\
80\end{array}$ & $\begin{array}{r}1,100 \\
80\end{array}$ & $\begin{array}{r}1,200 \\
80\end{array}$ \\
\hline Cumulative clawback (in dollars) & 387 & 774 & 1,161 & 1,548 & 1,935 & 2,320 & 2,691 & 3,063 & 3,435 & 3,806 & 4,178 & 4,517 \\
\hline $\begin{array}{l}\text { Cumulative income net of taxes } \\
\text { and clawback (in dollars) }\end{array}$ & 197 & 394 & 590 & 787 & 984 & 1,180 & 1,373 & 1,566 & 1,759 & 1,952 & 2,143 & 2,329 \\
\hline $\begin{array}{l}\text { Cumulative net income of } \\
\text { nonworking social assistance } \\
\text { recipient (in dollars) 6/ } \\
\text { Cumulative net income of working } \\
\text { social assistance recipient } \\
\text { (in dollars) 6/ }\end{array}$ & 1,113 & $\begin{array}{l}1,833 \\
2,227\end{array}$ & 3,340 & 4,454 & 5,567 & 6,680 & 7,790 & 8,899 & 10,009 & $\begin{array}{r}9,167 \\
11,118\end{array}$ & 12,228 & 13,329 \\
\hline $\begin{array}{l}\text { Effective average tax rate } 7 / \\
\text { Effective marginal tax rate } 7 /\end{array}$ & $\begin{array}{l}67.2 \\
80.5\end{array}$ & $\begin{array}{l}67.2 \\
80.5\end{array}$ & $\begin{array}{l}67.2 \\
80.5\end{array}$ & $\begin{array}{l}67.2 \\
80.5\end{array}$ & $\begin{array}{l}67.2 \\
80.5\end{array}$ & $\begin{array}{l}67.2 \\
81.2\end{array}$ & $\begin{array}{l}67.3 \\
81.2\end{array}$ & $\begin{array}{l}67.4 \\
81.2\end{array}$ & $\begin{array}{l}67.4 \\
81.2\end{array}$ & $\begin{array}{l}67.5 \\
81.2\end{array}$ & $\begin{array}{l}67.5 \\
81.2\end{array}$ & $\begin{array}{l}67.7 \\
84.6\end{array}$ \\
\hline $\begin{array}{l}\text { 1/ The average social assistance } b \\
2 / 3.2 \text { percent for income above } \$ \\
3 / 2.7 \text { percent for all insurable inc } \\
4 / 17 \text { percent for income over } \$ 6 \text {, } \\
5 / \text { Varies across provinces from } 7 \\
6 / \text { Assumes a single parent with o } \\
7 / \text { Total excludes provincial tax } r \\
\text { provinces. }\end{array}$ & $\begin{array}{l}500 \text { per } y \\
\text { ne in } 199 \\
6 . \\
\text { child rec } \\
\text { che pe } \\
\text { which }\end{array}$ & $\begin{array}{l}\text { year. } \\
\text { 98. Redu } \\
\text { ceent and } \\
\text { range fro }\end{array}$ & $\begin{array}{l}\text { arent wit } \\
\text { ced to } 2 . \\
\text { d is appli } \\
\text { enefits o } \\
\text { om } 45 \text { to }\end{array}$ & $\begin{array}{l}55 \text { perce } \\
\text { ied to net } \\
\text { if } \$ 11,00 \\
69 \text { perce }\end{array}$ & $\begin{array}{l}\text { int in } 19 \\
\text { incom } \\
\text { per } y \\
\text { nt of th }\end{array}$ & 9. & 1997. & & $x^{2}$ & 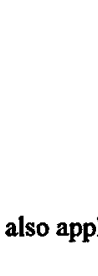 & . & \\
\hline
\end{tabular}

\section{Recent Developments in Provincial Social Assistance Programs}

9. Although the approach that has been taken across provinces varies widely, a number of generalizations can be drawn to describe recent provincial social assistance reforms. One feature that has been common across most reforming provinces is to divide social assistance 
recipients into two distinct groups: employable and unemployable (the disabled and mothers with young children). The rules and regulations governing social assistance benefits differ significantly depending on this classification, and only those rules and regulations governing employable recipients are discussed here. The typical provincial reform package applicable to employable individuals has reduced the generosity of benefits, tightened eligibility requirements, and strengthened training and employment search requirements (Table 5). ${ }^{6}$ There was also some effort to reduce the high effective marginal income tax rates faced by welfare recipients. Notably absent from the list of reforms is the introduction of time limits on the duration of benefits.

10. Of those provinces that adjusted the level of benefits, all but one (Nova Scotia) reduced benefits. Frequently, cutbacks were greater for single employable individuals than for employable individuals with dependent children. Ontario, Prince Edward Island, and Alberta enacted the largest relative cuts in benefits.

11. In several cases, steps were taken to significantly raise the bar for obtaining social assistance benefits. In Alberta, for example, program administrators adopted more intensive reviews of new and existing cases; required new applicants to attend information sessions before processing applications; required recipients to follow through on their case plans (including plans for finding employment) as a condition of continued eligibility; established waiting periods for non-emergency cases; and, in some districts, routinely denied first applications, except in certain hardship cases, to encourage applicants to pursue other means of support including employment. ${ }^{7}$ British Columbia ended eligibility altogether for people under 19 years of age, and Ontario extended the waiting period for recently unemployed individuals and placed new restrictions on the eligibility of cohabiting couples. In contrast, Québec eased eligibility somewhat by raising the ceiling on personal liquid assets above which an individual is excluded from receiving social assistance benefits.

12. Provinces generally strengthened training and job-search requirements as a condition of continued receipt of benefits. In many cases, refusal to participate in training and/or education programs intended to improve employment prospects can be grounds for ineligibility. Although in some cases such conditions were formally in place prior to the reform drive, enforcement was generally lax. The Ontario Works Program is a clear example of the trend toward social assistance programs with strict training and work requirements. In British Columbia, the strictest job search and training requirements were established for recipients ages 19-24.

${ }^{6} \mathrm{Brief}$ summaries of provincial reforms are available in a longer draft of this paper.

${ }^{7}$ For a detailed discussion of welfare reform in Alberta, see Boessenkool (1997), and National Council on Welfare (1997a). 
13. The introduction of the National Child Benefit in July 1998 helped to lower the marginal effective tax rate faced by certain very low-income workers, but did not change the effective rate for social assistance recipients. Because the National Child Benefit is separate from social assistance benefits, payments for children are no longer clawed back at low-tomoderate levels of earned income. However, while this lowers the marginal effective tax rates of certain low-income workers whose welfare benefits have been fully substituted by earned income, welfare recipients still face high rates of clawback of non-child benefits (see Appendix). As long as there are significant welfare benefits remaining that are subject to clawbacks, a social assistance recipient continues to face a high marginal effective income tax rate, and thus strong disincentives to work. Such disincentives could be dealt with by reducing the clawback rate, offering an earned income supplement, or by substituting a negative income $\operatorname{tax}^{8}$ for the traditional type of social assistance program. While some provinces have reduced the clawback rates of social assistance benefits and/or increased the earnings exemption, clawback rates remain high (Tables 5 and 6 ). Alberta enacted the most significant reduction in the clawback rate, reducing it from 90 percent to 75 percent. Saskatchewan introduced an earnings supplement that is designed to ensure that families would be better off working. Ontario and Newfoundland raised the earnings exemption to help offset a reduction in benefit levels.

\section{E. Considerations in Structuring Further Reforms}

14. Because it is difficult to measure the costs and benefits associated with the different approaches to welfare reform and because the precise goals for social assistance programs likely differ across provinces, no single optimal approach can be identified. The elements of any reform package can be separated into those factors that affect eligibility directly (the "sticks") and those that affect financial incentives (the "carrots"). The former address the specific criteria that must be met before administrators may certify eligibility. The latter address the relative appeal of social assistance benefits relative to work, which, in turn, influences an individual's choice between social assistance and work.

15. Restrictions that directly affect eligibility include: asset restrictions; duration restrictions; minimum age restrictions, training/education and/or work-search requirements; and various administrative measures such as waiting periods, fraud detection efforts, and routinely discouraging first-time applicants. A proper assessment of any of these measures requires consideration of the costs and benefits, which are difficult to quantify. In the case of asset restrictions, for example, although it is consistent with the goals of a social safety net to exclude from eligibility individuals with significant tangible and financial assets, such

\footnotetext{
${ }^{8} \mathrm{~A}$ negative income tax establishes a guaranteed minimum level of income support available to all working-age individuals. In its purest form, an unconditional income transfer would replace all other types of social assistance support (in-kind or cash). Earned income is then taxed according to statutory tax rates without any withdrawal of the income transfer.
} 
restrictions could also discourage saving by low-income workers and could penalize those with the longest work history. Restricting the duration of social assistance helps ensure that social support does not become an extended lifestyle choice, but it also implies that some of the truly needy could become unprotected. The same is true of age limits that, for example, might prohibit the participation of young people. Education/training and work-search requirements help to advance the goal of returning social assistance recipients to work, but both may also entail steep budgetary costs.

16. Policies affecting financial incentives include the generosity of benefits; benefit clawback rates; the earnings threshold below which benefits are not subject to clawbacks; earned income supplements for former welfare recipients; and the negative income tax approach to social assistance. Although cutting the generosity of social assistance benefits can reduce the financial incentive to seek or to retain benefits, at some point this will also undermine the adequacy and "fairness" of the social safety net. An overly generous system, on the other hand, may draw individuals from the labor force, implying a deadweight economic loss for the economy as a whole, and will be relatively costly in terms of budgetary outlays. Although lowering clawback rates will reduce the disincentive to work by reducing the marginal effective income tax rate, it also implies that social assistance recipients who enter the labor force will be better off than identical workers who have remained off of social assistance. Very low rates of clawback may thus create a "revolving door," whereby some low-skill workers will enter social assistance in order to achieve the higher-income levels available to them upon returning to work. Low clawbacks may also be deemed "unfair" by low-wage workers who have remained off social assistance. Earned income supplements for welfare recipients who choose to return to work will also reduce the marginal effective tax rate facing social assistance recipients and so improve work incentives. But income supplements are also subject to the "revolving door" and "unfairness" critiques. A negative income tax approach to social assistance ensures that the marginal effective tax rate facing low-wage workers and nonworkers is equalized, and thus does not discourage re-entry into the labor force. At the same time, however, this approach may draw workers from the labor force (imposing a deadweight loss on the economy) if the guaranteed income level is relatively high. Because such an income transfer is not targeted to the needy but is available across the board, it generally would be quite costly to adopt. If, on the other hand, the guaranteed level of income support were set very low, which would alleviate the problems mentioned above, it may not fulfill the objectives of a social safety net.

17. One possible reform that would appear not to have any drawbacks in terms of the objectives of a social safety net is to establish rules that reduce benefits and/or set time limits on the duration of benefits for employable social assistance recipients who reject repeated offers of employment. Repeated offers of employment can be taken as a strong indication that if social assistance benefits were to be reduced and eventually eliminated, such individuals would not fall through the social safety net but would return to the workforce. In order for this type of reform to work, however, it would have to be implemented in combination with a strict employment search obligation and adequate monitoring arrangements. 


\section{List of References}

Boessenkool, Kenneth, 1997, "Back to Work: Learning from the Alberta Welfare Experiment," C.D. Howe Institute Commentary (Toronto), April.

Clark, Christopher, 1998, Canada's Income Security Programs, Canadian Council on Social Development (Ottawa).

National Council of Welfare, 1998, Profiles of Welfare: Myths and Realities (Ottawa).

National Council of Welfare, 1997a, Another Look at Welfare Reform (Ottawa).

National Council of Welfare, 1997b, Welfare Incomes 1996 (Ottawa).

National Council of Welfare, 1996, Welfare Incomes, (Ottawa). 
Appendix: The National Child Benefit and Marginal Effective Income Tax Rates

\section{Representative Social Assistance Parameters:}

Suppose the monthly benefit for a single employable mother with one child is $\$ 400$ before the National Child Benefit (NCB).

Let the monthly benefit for a single employable mother with one child be $\$ 300$ after the NCB.

Assume the monthly NCB $=\$ 100$

Assume that the clawback rate is 80 percent and is applied to gross income. ${ }^{1}$

Monthly earnings exemption $=\$ 100$

\section{Notation:}

$\mathrm{PT}=$ payroll tax rate

$\mathrm{PIT}=$ personal income tax rate

MET = marginal effective income tax rate

\section{Before NCB}

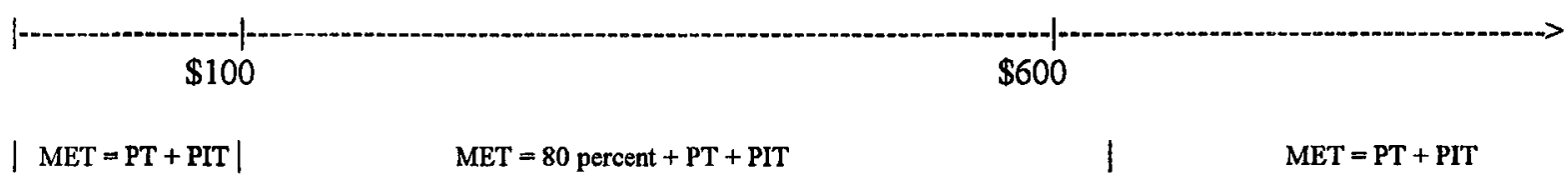

Monthly earned income

\section{After NCB}

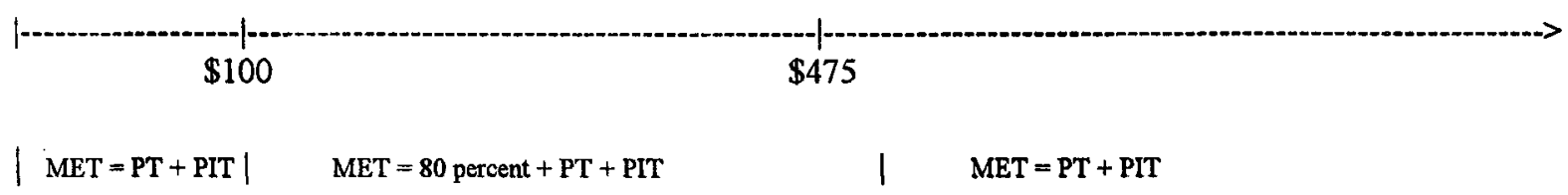

Monthly earned income

\footnotetext{
${ }^{1}$ Although clawbacks are typically applied to net earned income, this assumption simplifies the exposition and does not affect the conclusion. Applying the clawback rate to net income only increases the thresholds beyond which the marginal tax rate falls to PT + PIT.
} 
Table 1. Canada: Share of Population on Social Assistance, by Province, 1971-97 1/2/

(In percent of population)

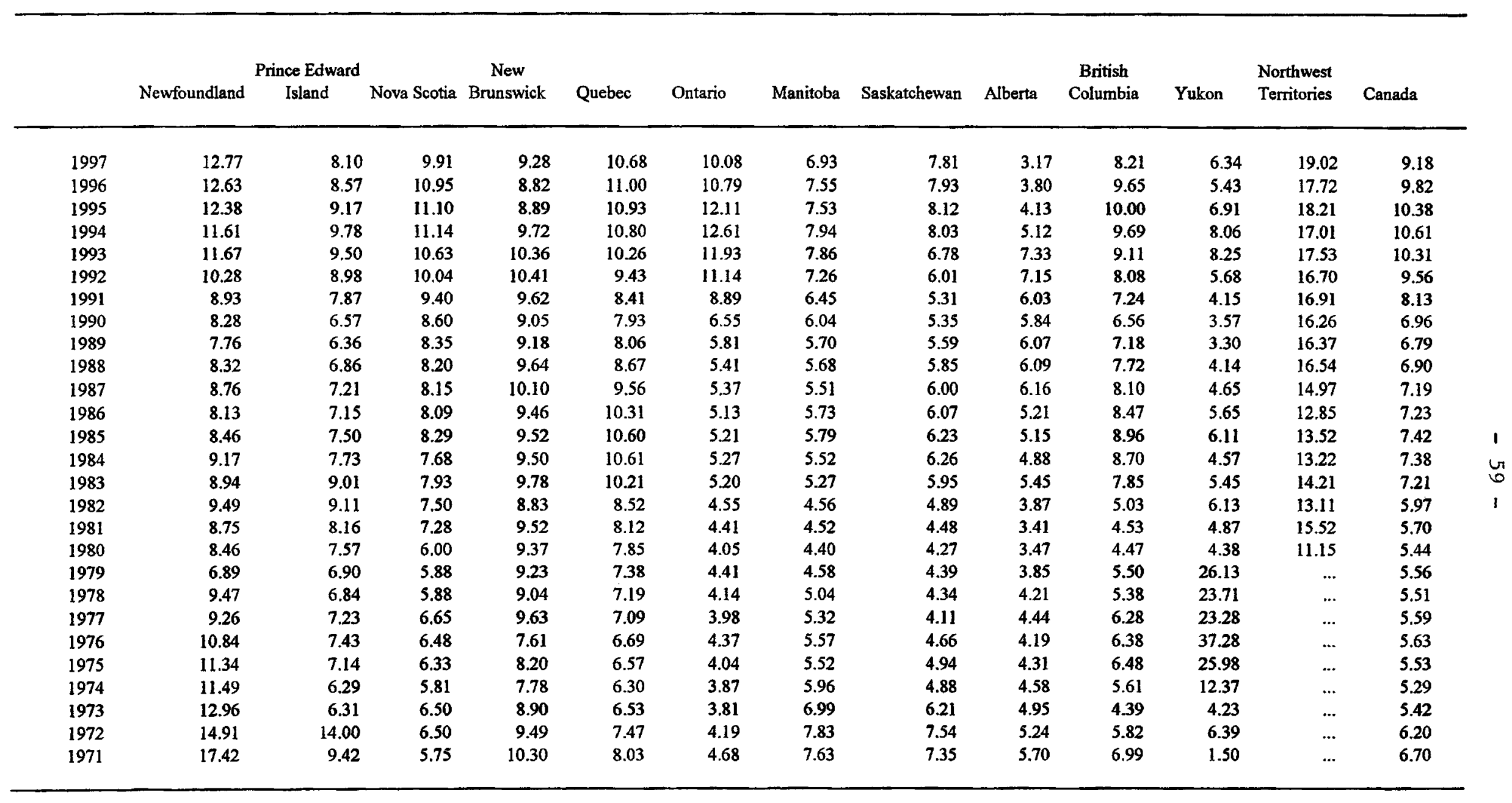

Sources: Human Resources Development Canada; and Fund staff estimates.

$1 /$ Including dependents.

2/ Fiscal year ending in March. 
Table 2. Canada: Per Capita Expenditures on Social Assistance, by Province, 1971-97 1/ (In 1997 dollars) 2/

\begin{tabular}{|c|c|c|c|c|c|c|c|c|c|c|c|c|c|}
\hline & Newfoundland & $\begin{array}{l}\text { Prince Edward } \\
\text { Island }\end{array}$ & Nova Scotia & $\begin{array}{c}\text { New } \\
\text { Brunswick }\end{array}$ & Quebec & Ontario & Manitoba & Saskatchewan & Alberta & $\begin{array}{c}\text { British } \\
\text { Columbia }\end{array}$ & Yukon & $\begin{array}{l}\text { Northwest } \\
\text { Territories }\end{array}$ & Canada \\
\hline 1997 & 447 & 282 & 390 & 327 & 469 & 500 & 298 & 313 & 138 & 396 & 270 & 532 & 421 \\
\hline 1996 & 436 & 298 & 404 & 323 & 497 & 597 & 320 & 318 & 160 & 464 & 250 & 497 & 476 \\
\hline 1995 & 406 & 327 & 405 & 344 & 500 & 640 & 326 & 324 & 179 & 482 & 299 & 540 & 498 \\
\hline 1994 & 360 & 358 & 397 & 369 & 501 & .655 & 348 & 317 & 298 & 484 & 336 & 512 & 515 \\
\hline 1993 & 326 & 340 & 367 & 395 & 466 & 619 & 344 & 264 & 378 & 441 & 302 & 463 & 492 \\
\hline 1992 & 280 & 312 & 330 & 390 & 414 & 529 & 286 & 224 & 349 & 373 & 229 & 435 & 427 \\
\hline 1991 & 252 & 282 & 286 & 353 & 338 & 378 & 243 & 207 & 291 & 318 & 151 & 400 & 335 \\
\hline 1990 & 234 & 241 & 264 & 356 & 366 & 292 & 228 & 216 & 295 & 311 & 117 & 408 & 307 \\
\hline 1989 & 218 & 237 & 257 & 371 & 369 & 262 & 218 & 233 & 303 & 328 & 99 & 409 & 299 \\
\hline 1988 & 231 & 240 & 243 & 364 & 425 & 245 & 214 & 245 & 301 & 352 & 99 & 381 & 310 \\
\hline 1987 & 230 & 237 & 235 & 366 & 419 & 228 & 201 & 260 & 287 & 374 & 112 & 311 & 303 \\
\hline 1986 & 214 & 232 & 229 & 365 & 446 & 216 & 201 & 262 & 248 & 403 & 158 & 276 & 306 \\
\hline 1985 & 212 & 226 & 220 & 368 & 432 & 210 & 192 & 262 & 221 & 411 & 136 & 244 & 298 \\
\hline 1984 & 224 & 236 & 208 & 351 & 412 & 200 & 178 & 257 & 216 & 395 & 136 & 261 & 285 \\
\hline 1983 & 214 & 270 & 196 & 358 & 357 & 179 & 148 & 241 & 218 & 325 & 172 & 265 & 254 \\
\hline 1982 & 204 & 247 & 183 & 318 & 300 & 156 & 126 & 186 & 150 & 211 & 141 & 246 & 206 \\
\hline 1981 & 217 & 232 & 177 & 322 & 292 & 152 & 126 & 176 & 135 & 211 & 117 & 267 & 202 \\
\hline 1980 & 211 & 212 & 177 & 311 & 279 & 153 & 124 & 177 & 150 & 242 & 66 & 243 & 203 \\
\hline 1979 & 213 & 206 & 175 & 336 & 272 & 158 & 135 & 179 & 164 & 220 & 83 & 266 & 203 \\
\hline 1978 & 217 & 190 & 184 & 280 & 269 & 160 & 133 & 168 & 185 & 232 & 81 & 198 & 204 \\
\hline 1977 & 236 & 188 & 175 & 409 & 261 & 156 & 137 & 200 & 180 & 221 & 57 & 186 & 205 \\
\hline 1976 & 243 & 168 & 167 & 331 & 236 & 167 & 144 & 137 & 164 & 246 & 93 & 286 & 199 \\
\hline 1975 & 257 & 152 & 150 & 256 & 211 & 154 & 142 & 143 & 153 & 254 & 68 & 469 & 185 \\
\hline 1974 & 210 & 115 & 150 & 221 & 203 & 131 & 145 & 181 & 151 & 163 & 70 & 40 & 163 \\
\hline 1973 & 280 & 126 & 131 & 203 & 226 & 133 & 174 & 169 & 178 & 172 & 66 & $\ldots$ & 175 \\
\hline 1972 & 313 & 124 & 141 & 184 & 224 & 153 & 194 & 164 & 160 & 184 & 27 & $\ldots$ & 183 \\
\hline 1971 & 290 & 123 & 111 & 149 & 168 & 129 & 181 & 138 & 160 & 194 & 59 & $\ldots$ & 155 \\
\hline
\end{tabular}

Sources: Human Resources Development Canada; and Fund staff estimates.

1/ Fiscal year ending in March.

2/ Deflated using consumer price index. 
Table 3. Canada: Social Assistance Cases by Length of Spell, 1990-97

\begin{tabular}{|c|c|c|c|c|c|c|c|}
\hline Length of Spell & 1990 & 1992 & 1994 & 1995 & 1996 & 1997 & $\begin{array}{r}\text { Percent } \\
\text { Change } \\
1990-97 \\
\end{array}$ \\
\hline $0-3$ months & 152,111 & 238,643 & 210,024 & 198,048 & 156,696 & 143,287 & -5.8 \\
\hline In percent of total & 24 & 25 & 19 & 18 & 16 & 15 & \\
\hline 4-6 months & 69,100 & 131,643 & 123,987 & 114,667 & 98,277 & 88,024 & 27.4 \\
\hline In percent of total & 11 & 14 & 11 & 11 & 10 & 9 & \\
\hline 7-12 months & 70,597 & 136,935 & 143,098 & 132,916 & 120,786 & 99,617 & 41.1 \\
\hline In percent of total & 11 & 14 & 13 & 12 & 12 & 11 & \\
\hline 13-24 months & 81,606 & 142,446 & 186,337 & 175,234 & 159,933 & 139,477 & 70.9 \\
\hline In percent of total & 13 & 15 & 17 & 16 & 16 & 15 & \\
\hline $25+$ months & 260,809 & 305,968 & 430,091 & 461,336 & 472,833 & 472,763 & 81.3 \\
\hline In percent of total & 41 & 32 & 39 & 43 & 47 & 50 & \\
\hline Total $1 /$ & 634,223 & 955,635 & $1,093,537$ & $1,082,201$ & $1,008,525$ & 943,168 & 48.7 \\
\hline
\end{tabular}

Source: National Council of Welfare (1998).

1/ Total includes social assistance cases from all provinces and territories, except for New Brunswick, Quebec, and municipal social assistance cases in Nova Scotia and Manitoba, and accounts for between 60 and 66 percent of total national social assistance cases. 


\begin{tabular}{|c|c|c|c|c|c|c|c|c|c|c|c|c|c|}
\hline & \multirow[b]{4}{*}{1986} & \multirow[b]{4}{*}{1989} & \multirow[b]{4}{*}{1990} & \multirow[b]{4}{*}{1991} & \multirow[b]{4}{*}{1992} & \multirow[b]{4}{*}{1993} & \multirow[b]{4}{*}{1994} & \multirow[b]{4}{*}{1995} & \multirow[b]{4}{*}{1996} & \multirow[b]{4}{*}{1997} & \multicolumn{3}{|c|}{ Benefits in Percent of } \\
\hline & & & & & & & & & & & \multirow{3}{*}{$\begin{array}{r}\text { Provincial } \\
\text { Minimum } \\
\text { Wages } \\
1997\end{array}$} & \multirow{2}{*}{\multicolumn{2}{|c|}{$\begin{array}{l}\text { 2/3 Average } \\
\text { Income 1/ }\end{array}$}} \\
\hline & & & & & & & & & & & & & \\
\hline & & & & & & & & & & & & 1993 & 1997 \\
\hline \multicolumn{14}{|l|}{ Newfoundland } \\
\hline Single employable & 4,595 & 4,430 & $\mathbf{4 , 4 0 8}$ & 4,335 & 4,555 & 4,499 & 4,486 & 4,395 & 2,502 & 4,252 & 41 & 28 & 26 \\
\hline Disabled person & & 8,925 & 8,839 & 8,562 & 8,767 & 8,642 & 8,617 & 8,443 & 8,310 & 8,167 & 79 & 55 & 50 \\
\hline Single parent, one child & 11,521 & 11,279 & 11,268 & 11,380 & 11,859 & 11,712 & 11,679 & 11,442 & 11,262 & 11,068 & 107 & 74 & 67 \\
\hline Couple, two children & 13,327 & 13,048 & 13,030 & 12,596 & 12,834 & 12,673 & 12,637 & 12,381 & 12,186 & 11,976 & 116 & 80 & 73 \\
\hline \multicolumn{14}{|l|}{ Prince Edward Island } \\
\hline Single employable & 8,535 & 8,254 & 8,223 & 8,210 & 8,336 & 8,274 & 7,425 & 5,725 & 5,245 & 5,225 & 49 & 62 & 37 \\
\hline Disabled person & & 9,606 & 9,517 & 9,370 & 9,493 & 9,410 & 9,283 & 8,939 & 9,048 & 8,774 & 83 & 71 & 62 \\
\hline Single parent, one child & 11,765 & 11,379 & 11,478 & 11,374 & 11,564 & 11,494 & 11,262 & 10,733 & 10,242 & 9,800 & 92 & 87 & 69 \\
\hline Couple, two children & 17,240 & 16,948 & 16,961 & 17,039 & 17,265 & 17,130 & 16,782 & 16,117 & 14,873 & 14,718 & 139 & 129 & 103 \\
\hline \multicolumn{14}{|l|}{ Nova Scotia } \\
\hline Single employable & 6,273 & 6,991 & 6,676 & 6,341 & 6,252 & 6,140 & 6,122 & $\$, 998$ & 5,922 & 4,352 & 40 & 38 & 28 \\
\hline Disabled person & & 9,203 & 9,153 & 9,009 & 8,896 & 8,736 & 8,860 & 8,705 & 8,568 & 8,421 & 78 & 54 & 54 \\
\hline Single parent, one child & 10,863 & 11,186 & 11,114 & 10,968 & 10,980 & 10,783 & 10,923 & 10,729 & 10,560 & 9,211 & 85 & 67 & 59 \\
\hline Couple, two children & 13,076 & 14,230 & 13,609 & 13,137 & 13,165 & 12,971 & 12,933 & 12,672 & 13,602 & 13,751 & 127 & 80 & 88 \\
\hline \multicolumn{14}{|l|}{ New Brunswick } \\
\hline Single employable & 3,092 & 3,343 & 3,296 & 3,222 & 3,228 & 3,182 & 3,198 & 3,146 & 3,132 & 3,114 & 29 & 19 & 19 \\
\hline Disabled person & & 8,761 & 8,631 & $8 ; 369$ & 8,387 & 8,332 & 6,529 & 6,511 & 6,483 & 6,548 & 61 & 51 & 40 \\
\hline Single parent, one child & 9,286 & 9,065 & 8,930 & 8,721 & 8,794 & 8,819 & 9,171 & 9,628 & 9,573 & 9,800 & 91 & 54 & 61 \\
\hline Couple, two children & 10,045 & 9,807 & 9,648 & 9,546 & 9,868 & 9,892 & 10,241 & 10,778 & 10,711 & 11,133 & 103 & 61 & 69 \\
\hline \multicolumn{14}{|l|}{ Quebec } \\
\hline Single employable & 3,254 & 4,179 & 5,935 & 6,156 & 6,348 & 6,365 & 6,222 & 6,096 & 6,000 & 5,808 & 52 & 34 & 31 \\
\hline Disabled person & & 7,513 & 7,800 & 8,012 & 8,267 & 8,262 & 8,387 & 8,217 & 8,268 & 8,244 & 74 & 45 & 45 \\
\hline Single parent, one child & 10,951 & 10,154 & 10,828 & 9,897 & 11,250 & 11,715 & 11,955 & 11,713 & 11,528 & 10,738 & 96 & 63 & 58 \\
\hline Couple, two children & 14,154 & 13,261 & 12,986 & 13,351 & 13,820 & 14,227 & 14,024 & 13,741 & 13,524 & 12,610 & 113 & 77 & 68 \\
\hline \multicolumn{14}{|l|}{ Ontario } \\
\hline Single employable & 6,955 & $\mathbf{7 , 4 7 4}$ & 8,166 & 8,371 & 8,669 & 8,638 & 8,634 & 8,024 & 6,584 & 6,133 & 46 & 45 & 32 \\
\hline Disabled person & & 10,791 & 11,520 & 11,760 & 11,969 & 11,898 & 11,890 & 11,650 & 11,466 & 10,968 & 81 & 62 & 57 \\
\hline Single parent, one child & 12,456 & 13,413 & 15,042 & 15,394 & 15,691 & 15,663 & 15,657 & 14,535 & 11,940 & 11,390 & 85 & 81 & 59 \\
\hline Couple, two children & 15,505 & 16,927 & 19,737 & 20,081 & 20,540 & 20,483 & 20,286 & 18,716 & 15,428 & 14,717 & 109 & 106 & 76 \\
\hline
\end{tabular}


Table 4. Canada: Provincial and Territorial Social Assistance Benefits (Concluded)

(In constant 1996 dollars, unless otherwise noted)

\begin{tabular}{|c|c|c|c|c|c|c|c|c|c|c|c|c|c|}
\hline & \multirow[b]{5}{*}{1986} & \multirow[b]{5}{*}{1989} & \multirow[b]{5}{*}{1990} & \multirow[b]{5}{*}{1991} & \multirow[b]{5}{*}{1992} & \multirow[b]{5}{*}{1993} & \multirow[b]{5}{*}{1994} & \multirow[b]{5}{*}{1995} & \multirow[b]{5}{*}{1996} & \multirow[b]{5}{*}{1997} & \multicolumn{3}{|c|}{ Benefits in Percent of: } \\
\hline & & & & & & & & & & & \multirow{4}{*}{$\begin{array}{r}\text { Provincial } \\
\text { Minimum } \\
\text { Wages } \\
1997\end{array}$} & \multirow{3}{*}{\multicolumn{2}{|c|}{$\begin{array}{l}2 / 3 \text { Average } \\
\text { Income } 1 /\end{array}$}} \\
\hline & & & & & & & & & & & & & \\
\hline & & & & & & & & & & & & & \\
\hline & & & & & & & & & & & & 1993 & 1997 \\
\hline \multicolumn{14}{|l|}{ Manitoba } \\
\hline Single employable & 6,901 & 7,157 & $\mathbf{7 , 2 5 5}$ & 7,159 & 7,313 & 7,193 & 6,687 & 6,562 & $\mathbf{6 , 0 7 0}$ & 5,260 & 50 & 43 & 32 \\
\hline Disabled person & & 7,782 & 7,686 & 7,550 & 9,294 & 8,368 & 8,293 & 8,125 & 7,997 & 7,859 & 74 & 50 & 48 \\
\hline Single parent, one child & 10,661 & 10,444 & 10,325 & 10,141 & 11,244 & 10,085 & 9,993 & 9,790 & 9,636 & 9,470 & 89 & 60 & 57 \\
\hline Couple, two children & 16,153 & 16,950 & 18,250 & 18,235 & 18,788 & 17,125 & 17,405 & 17,042 & 15,273 & 13,987 & 132 & 101 & 85 \\
\hline \multicolumn{14}{|l|}{ Saskatchewan } \\
\hline Single employable & 5,777 & 5,779 & 5,652 & 5,477 & 5,692 & 5,990 & 5,973 & 5,852 & 5,760 & 5,661 & 51 & 37 & 33 \\
\hline Disabled person & & 9,417 & 9,125 & 8,764 & 8,694 & 8,611 & 8,586 & 8,412 & 8,520 & $\mathbf{7 , 3 7 1}$ & 67 & 53 & 43 \\
\hline Single parent, one child & 11,853 & 11,803 & 11,475 & 11,033 & 10,919 & 10,796 & 10,765 & 10,548 & 10,381 & 10,252 & 93 & 67 & 60 \\
\hline Couple, two children & 16,627 & 16,377 & 15,913 & 15,279 & 15549 & 15,333 & 15,348 & 15,040 & 14,803 & 14,602 & 133 & 95 & 86 \\
\hline \multicolumn{14}{|l|}{ Alberta } \\
\hline Single employable & 8,220 & 5,711 & 5,451 & 5,922 & 5,973 & 5,628 & 4,903 & 4,804 & 4,728 & 4,682 & 48 & 32 & 26 \\
\hline Disabled person & & 7,063 & 6,742 & 7,092 & 7,053 & 6,845 & 6,811 & 6,693 & 6,588 & 9,600 & 98 & 38 & 54 \\
\hline Single parent, one child & 12,036 & 10,708 & 10,222 & 10,715 & 10,700 & 10,271 & 9,532 & 9,339 & 9,192 & 9,164 & 93 & 58 & 52 \\
\hline Couple, two children & 17,895 & 15,777 & 15,060 & 16,585 & 16,622 & 16,006 & 15,007 & 14,856 & 14,622 & 14,488 & 147 & 90 & 82 \\
\hline \multicolumn{14}{|l|}{ British Columbia } \\
\hline Single employable & 5,871 & 6,440 & 6,588 & 6,476 & 6,680 & 6,701 & 6,860 & 6,743 & 6,131 & 5,976 & 43 & 33 & 28 \\
\hline Disabled person & & 8,887 & 9,198 & 8,976 & 9,379 & 9,440 & 9,649 & 9,486 & 9,337 & 9,127 & 66 & 46 & 43 \\
\hline Single parent, one child & 10,574 & 11,633 & 11,763 & 11,514 & 12,044 & 12,084 & 12,367 & 12,155 & 11,964 & 11,660 & 85 & 59 & 55 \\
\hline Couple, two children & 14,443 & 14,530 & 14,639 & 14,285 & 15,238 & 15,324 & 15,771 & 15,502 & 15,258 & 15,389 & 112 & 75 & 72 \\
\hline \multicolumn{14}{|l|}{ Yukon } \\
\hline Single employable & 6,977 & 8,419 & 8,525 & 8376 & 8,361 & 8,211 & 8,187 & 8,021 & 7,895 & 7,759 & 58 & 40 & 35 \\
\hline Disabled person & & 9,418 & 9,478 & 9,278 & 9,250 & 9,084 & 9,058 & 9,545 & 9,395 & 9,233 & 68 & 44 & 42 \\
\hline Single Parent, One Child & 12,529 & 13,916 & 14,010 & 13,876 & 13,886 & 13,636 & 13,597 & 13,322 & 13,112 & 12,886 & 96 & 66 & 59 \\
\hline Couple, two children & 19,197 & 20,891 & 20,764 & 20,740 & 20,931 & 20,556 & 20,496 & 20,081 & 19,765 & 19,425 & 144 & 100 & 88 \\
\hline \multicolumn{14}{|l|}{ Northwest Territories } \\
\hline Single Employable & & & & & & 11,756 & 11,722 & 11,485 & 11,229 & 7,607 & 60 & 51 & 32 \\
\hline Disabled Penson & & & & & & 13,316 & 13,278 & 13,009 & 13,029 & 9,376 & $\mathbf{T 3}$ & 58 & 40 \\
\hline Single Parent, One Child & & & & & & 19,931 & 19,873 & 19,471 & 19,074 & 17,018 & 133 & 87 & 72 \\
\hline Couple, Two Children & & & & & & 23,587 & 23,556 & 23,079 & 22,596 & 21,287 & 167 & 103 & 90 \\
\hline
\end{tabular}

Sources: National Council of Welfare, (1997b); Clark (1998); and Statistics Canada.

$1 /$ Average income calculated as average hourty earnings of employees paid by the hour for each province or territory multiplied by 2,000 hours, which proxies for the average. 
Table 5. Canada: Recent Welfare Reforms, by Province 1/

\begin{tabular}{|c|c|c|c|c|c|c|}
\hline & $\begin{array}{l}\text { Measures to } \\
\text { Reduce High } \\
\text { Effective } \\
\text { Marginal Tax } \\
\text { Rates? }\end{array}$ & Workfare? & $\begin{array}{l}\text { Generosity } \\
\text { of Benefits? }\end{array}$ & $\begin{array}{l}\text { Time } \\
\text { Limits? }\end{array}$ & $\begin{array}{l}\text { Eligibility } \\
\text { Restrictions? }\end{array}$ & $\begin{array}{l}\text { Summary of } \\
\text { Approach to } \\
\text { Welfare Reform }\end{array}$ \\
\hline $\begin{array}{l}\text { British } \\
\text { Columbia }\end{array}$ & $\begin{array}{l}\text { The Family } \\
\text { Bonus income } \\
\text { supplement } \\
\text { improved the } \\
\text { income of } \\
\text { working families } \\
\text { relative to } \\
\text { welfare } \\
\text { recipients. } \\
\text { Because the } \\
\text { Family Bonus is } \\
\text { deducted from } \\
\text { welfare benefits, } \\
\text { it does not reduce } \\
\text { the clawback rate } \\
\text { facing welfare } \\
\text { recipients. }\end{array}$ & $\begin{array}{l}\text { Strengthened } \\
\text { requirements for } \\
\text { job search and } \\
\text { training for } \\
\text { employable } \\
\text { recipients. } \\
\text { Refusing to } \\
\text { accept or pursue } \\
\text { work is grounds } \\
\text { for ineligibility } \\
\text { for employable } \\
\text { individuals. }\end{array}$ & $\begin{array}{l}\text { Essentially } \\
\text { unchanged. }\end{array}$ & $\begin{array}{l}\text { No } \\
\text { explicit } \\
\text { limits. }\end{array}$ & $\begin{array}{l}\text { Young people } \\
\text { under } 19 \text { no } \\
\text { longer } \\
\text { eligible. Strict } \\
\text { job search } \\
\text { and/or } \\
\text { training } \\
\text { requirements } \\
\text { for } 19-24 \\
\text { year olds. } \\
\text { Adults } 25 \text { and } \\
\text { over must } \\
\text { seek and } \\
\text { accept work if } \\
\text { offered, but } \\
\text { subject to less } \\
\text { regimented } \\
\text { criteria. }\end{array}$ & $\begin{array}{l}\text { Emphasis on job } \\
\text { search and } \\
\text { training for } \\
\text { employment. } \\
\text { Also improved } \\
\text { the incomes } \\
\text { available to } \\
\text { working parents } \\
\text { through the } \\
\text { Family Bonus. }\end{array}$ \\
\hline Alberta & $\begin{array}{l}\text { Reduced the } \\
\text { clawback rate } \\
\text { from } 90 \text { percent } \\
\text { to } 75 \text { percent. }\end{array}$ & $\begin{array}{l}\text { Recipients must } \\
\text { actively seek } \\
\text { work or enter } \\
\text { training when } \\
\text { youngest child } \\
\text { reaches six } \\
\text { months (the old } \\
\text { policy was two } \\
\text { years). The } \\
\text { province became } \\
\text { more likely to cut } \\
\text { off benefits to } \\
\text { those refusing } \\
\text { work without } \\
\text { good cause. }\end{array}$ & $\begin{array}{l}\text { Benefits } \\
\text { reduced } \\
\text { (between } \\
12-19 \text { per- } \\
\text { cent) to } \\
\text { bring them } \\
\text { in line with } \\
\text { incomes of } \\
\text { low-wage } \\
\text { workers. }\end{array}$ & $\begin{array}{l}\text { No } \\
\text { explicit } \\
\text { limits. }\end{array}$ & $\begin{array}{l}\text { Administrativ } \\
\text { e restrictions: } \\
\text { e.g., Officials } \\
\text { routinely deny } \\
\text { first } \\
\text { applications; } \\
\text { enhanced } \\
\text { follow-up } \\
\text { checks to } \\
\text { verify } \\
\text { eligibility; } \\
\text { increased } \\
\text { fraud } \\
\text { investigations } \\
\text {; enhanced } \\
\text { home visits to } \\
\text { verify } \\
\text { eligibility; } \\
\text { waiting } \\
\text { periods } \\
\text { established. }\end{array}$ & $\begin{array}{l}\text { Reforms did little } \\
\text { to reduce work } \\
\text { disincentives for } \\
\text { those already } \\
\text { receiving } \\
\text { benefits. To } \\
\text { discourage new } \\
\text { welfare cases, } \\
\text { emphasized less } \\
\text { generous benefits } \\
\text { and tighter } \\
\text { eligibility } \\
\text { restrictions } \\
\text { through changes } \\
\text { in administrative } \\
\text { practices. }\end{array}$ \\
\hline
\end{tabular}


Table 5. Canada: Recent Welfare Reforms, by Province 1/

\begin{tabular}{|c|c|c|c|c|c|c|}
\hline & $\begin{array}{l}\text { Measures to } \\
\text { Reduce High } \\
\text { Effective } \\
\text { Marginal Tax } \\
\text { Rates? }\end{array}$ & Workfare? & $\begin{array}{l}\text { Generosity } \\
\text { of Benefits? }\end{array}$ & $\begin{array}{l}\text { Time } \\
\text { Limits? }\end{array}$ & $\begin{array}{l}\text { Eligibility } \\
\text { Restrictions? }\end{array}$ & $\begin{array}{l}\text { Summary of } \\
\text { Approach to } \\
\text { Welfare Reform }\end{array}$ \\
\hline Ontario & $\begin{array}{l}\text { No earnings } \\
\text { exemption for the } \\
\text { first three months } \\
\text { on welfare. } \\
\text { Earnings exemp- } \\
\text { tion was raised to } \\
\text { offset a cut in } \\
\text { benefit levels. } \\
\text { The clawback } \\
\text { rate after the } \\
\text { exemption is } \\
75 \text { percent. }\end{array}$ & $\begin{array}{l}\text { Ontario Works } \\
\text { requires recipi- } \\
\text { ents of social } \\
\text { assistance to } \\
\text { pursue work } \\
\text { and/or training, } \\
\text { and refusal to } \\
\text { accept work can } \\
\text { eventually lead to } \\
\text { ineligibility for } \\
\text { social assistance. }\end{array}$ & $\begin{array}{l}\text { Benefits } \\
\text { were cut by } \\
211 / 2 \text { percent } \\
\text { for all but } \\
\text { the elderly } \\
\text { and } \\
\text { disabled. }\end{array}$ & $\begin{array}{l}\text { No } \\
\text { explicit } \\
\text { limits. }\end{array}$ & $\begin{array}{l}\text { Extension of } \\
\text { the waiting } \\
\text { period for } \\
\text { employable } \\
\text { person who } \\
\text { quits or loses } \\
\text { a job without } \\
\text { just cause; } \\
\text { restrictions on } \\
\text { cohabiting } \\
\text { couples. }\end{array}$ & $\begin{array}{l}\text { Primarily } \\
\text { workfare } \\
\text { combined with } \\
\text { benefit cuts. }\end{array}$ \\
\hline Newfoundland & $\begin{array}{l}\text { Earnings exemp- } \\
\text { tion for families } \\
\text { was increased. } \\
\text { Pilot income } \\
\text { supplement } \\
\text { program will be } \\
\text { introduced. }\end{array}$ & None. & $\begin{array}{l}\text { Benefits } \\
\text { declined in } \\
\text { real terms by } \\
7 \text { percent } \\
\text { over the } \\
\text { period } \\
1992-97 \\
\text { and were } \\
\text { raised by } \\
2 \text { percent in } \\
1998 \text {. }\end{array}$ & $\begin{array}{l}\text { No } \\
\text { explicit } \\
\text { limits. }\end{array}$ & $\begin{array}{l}\text { No explicit } \\
\text { restrictions. }\end{array}$ & $\begin{array}{l}\text { Emphasis on job } \\
\text { search and } \\
\text { training for } \\
\text { employment. } \\
\text { Reduced disin- } \\
\text { centives to work. }\end{array}$ \\
\hline $\begin{array}{l}\text { Prince Edward } \\
\text { Island }\end{array}$ & None. & None. & $\begin{array}{l}\text { Benefits } \\
\text { reduced by } \\
37 \text { percent } \\
\text { for single } \\
\text { persons and } \\
15 \text { percent } \\
\text { for families. }\end{array}$ & $\begin{array}{l}\text { No } \\
\text { explicit } \\
\text { limits. }\end{array}$ & $\begin{array}{l}\text { No explicit } \\
\text { restrictions. }\end{array}$ & Benefit cuts. \\
\hline
\end{tabular}


Table 5. Canada: Recent Welfare Reforms, by Province 1/

\begin{tabular}{|c|c|c|c|c|c|c|}
\hline & $\begin{array}{l}\text { Measures to } \\
\text { Reduce High } \\
\text { Effective } \\
\text { Marginal Tax } \\
\text { Rates? }\end{array}$ & Workfare? & $\begin{array}{l}\text { Generosity } \\
\text { of Benefits? }\end{array}$ & $\begin{array}{l}\text { Time } \\
\text { Limits? }\end{array}$ & $\begin{array}{l}\text { Eligibility } \\
\text { Restrictions? }\end{array}$ & $\begin{array}{l}\text { Summary of } \\
\text { Approach to } \\
\text { Welfare Reform }\end{array}$ \\
\hline $\begin{array}{l}\text { New } \\
\text { Brunswick }\end{array}$ & $\begin{array}{l}\text { Introduced } \\
\text { extended wage } \\
\text { exemption. } \\
\text { Allows families } \\
\text { (single } \\
\text { individual) a } \\
\$ 200(\$ 150) \text { per } \\
\text { month exemption } \\
\text { plus } 35(30) \text { per- } \\
\text { cent of income on } \\
\text { any additional } \\
\text { income for the } \\
\text { first six months, } \\
\text { and } 30(25) \text { per- } \\
\text { cent for the } \\
\text { second six } \\
\text { months. }\end{array}$ & $\begin{array}{l}\text { Beneficiaries } \\
\text { under the age of } \\
21 \text { are required } \\
\text { to attend school } \\
\text { or participate in } \\
\text { training to } \\
\text { receive } \\
\text { maximum } \\
\text { benefits. } \\
\text { Noncompliance } \\
\text { results in } \\
\text { substantial } \\
\text { reductions in } \\
\text { benefit levels. }\end{array}$ & $\begin{array}{l}\text { Essentially } \\
\text { unchanged. }\end{array}$ & $\begin{array}{l}\text { No } \\
\text { explicit } \\
\text { limits. }\end{array}$ & $\begin{array}{l}\text { No explicit } \\
\text { restrictions. }\end{array}$ & $\begin{array}{l}\text { Emphasis on job } \\
\text { search and. } \\
\text { training; reduced } \\
\text { disincentives to } \\
\text { work. }\end{array}$ \\
\hline Nova Scotia & $\begin{array}{l}\text { None. Under } \\
\text { Family Benefits, } \\
\text { individuals with- } \\
\text { out dependents } \\
\text { are allowed } \$ 100 \\
\text { per month in } \\
\text { earned income } \\
\text { without reduced } \\
\text { benefits; there- } \\
\text { after, } 75 \text { percent } \\
\text { of gross earnings } \\
\text { are charged } \\
\text { against benefits. } \\
\text { The earnings } \\
\text { exemption is } \\
\text { doubled for } \\
\text { individuals with } \\
\text { dependents. }\end{array}$ & $\begin{array}{l}\text { Social assistance } \\
\text { recipients are } \\
\text { required to seek } \\
\text { work and accept } \\
\text { available } \\
\text { employment; also } \\
\text { required to } \\
\text { undertake } \\
\text { training as a } \\
\text { condition of } \\
\text { eligibility. }\end{array}$ & $\begin{array}{l}\text { Social } \\
\text { assistance } \\
\text { benefits } \\
\text { were } \\
\text { increased } \\
\text { in some } \\
\text { regions to } \\
\text { meet the } \\
\text { higher levels } \\
\text { offered by } \\
\text { the more } \\
\text { costly } \\
\text { munici- } \\
\text { palities. }\end{array}$ & $\begin{array}{l}\text { No } \\
\text { explicit } \\
\text { time } \\
\text { limits. }\end{array}$ & $\begin{array}{l}\text { Limits on } \\
\text { liquid assets. }\end{array}$ & $\begin{array}{l}\text { Consolidated } \\
\text { programs that } \\
\text { had been set up } \\
\text { and administered } \\
\text { by municipalities } \\
\text { into a provincial } \\
\text { system. }\end{array}$ \\
\hline
\end{tabular}


Table 5. Canada: Recent Welfare Reforms, by Province 1/

\begin{tabular}{|c|c|c|c|c|c|c|}
\hline & $\begin{array}{l}\text { Measures to } \\
\text { Reduce High } \\
\text { Effective } \\
\text { Marginal Tax } \\
\text { Rates? }\end{array}$ & Workfare? & $\begin{array}{l}\text { Generosity } \\
\text { of Benefits? }\end{array}$ & $\begin{array}{l}\text { Time } \\
\text { Limits? }\end{array}$ & $\begin{array}{l}\text { Eligibility } \\
\text { Restrictions? }\end{array}$ & $\begin{array}{l}\text { Summary of } \\
\text { Approach to } \\
\text { Welfare Reform }\end{array}$ \\
\hline Saskatchewan & $\begin{array}{l}\text { The } \\
\text { Saskatchewan } \\
\text { Employment } \\
\text { Supplement } \\
\text { ensures that } \\
\text { families are } \\
\text { better off } \\
\text { working than } \\
\text { receiving social } \\
\text { assistance } \\
\text { benefits. }\end{array}$ & None. & $\begin{array}{l}\text { Essentially } \\
\text { unchanged. }\end{array}$ & $\begin{array}{l}\text { No } \\
\text { explicit } \\
\text { limits. }\end{array}$ & $\begin{array}{l}\text { To be eligible } \\
\text { for the } \\
\text { Saskatchewan } \\
\text { Employment } \\
\text { Supplement, } \\
\text { a family must } \\
\text { reside in the } \\
\text { province; } \\
\text { have a valid } \\
\text { social insur- } \\
\text { ance number; } \\
\text { and have at } \\
\text { least } \$ 125 \text { in } \\
\text { employment } \\
\text { income per } \\
\text { month. }\end{array}$ & $\begin{array}{l}\text { Employment } \\
\text { Supplement } \\
\text { combined with } \\
\text { emphasis on job } \\
\text { search and } \\
\text { training for } \\
\text { employment. }\end{array}$ \\
\hline Quebec & $\begin{array}{l}\text { Earnings } \\
\text { exemption for } \\
\text { recipients will be } \\
\text { increased. }\end{array}$ & $\begin{array}{l}\text { Employment } \\
\text { Assistance } \\
\text { Allowance will } \\
\text { be offered to } \\
\text { welfare benefici- } \\
\text { aries who partici- } \\
\text { pate in an indivi- } \\
\text { dualized training } \\
\text { and employment } \\
\text { plan; only able } \\
\text { beneficiaries } \\
\text { between the ages } \\
\text { of } 18-24 \text { will be } \\
\text { required to } \\
\text { participate. A } \\
\text { Return to Work } \\
\text { Supplement } \\
\text { grants } \$ 500 \text { to } \\
\text { beneficiaries who } \\
\text { find a new job. }\end{array}$ & $\begin{array}{l}\text { Essentially } \\
\text { unchanged. }\end{array}$ & $\begin{array}{l}\text { No } \\
\text { explicit } \\
\text { limits. }\end{array}$ & $\begin{array}{l}\text { Increased } \\
\text { permissible } \\
\text { level of liquid } \\
\text { assets. }\end{array}$ & $\begin{array}{l}\text { Emphasis on job } \\
\text { search and } \\
\text { training for } \\
\text { employment. }\end{array}$ \\
\hline
\end{tabular}

Sources: National Council of Welfare (1997a); Boessenkool (1997); and various provincial ministries responsible for social assistance.

1/ Information on reforms in Manitoba was unavailable. 
Table 6. Canada: Monthly Earnings Exemptions and Clawback Rates for Employable Individuals on Welfare

\begin{tabular}{|c|c|c|}
\hline & Maximum Earnings Exemption & Clawback Rate \\
\hline Newfoundland & $\begin{array}{l}\$ 40 \text { for unemployed single adults; } \$ 100 \\
\text { for unemployed family, no children; and } \\
\$ 150 \text { family with dependent children. }\end{array}$ & 100 percent. \\
\hline Prince Edward Island & $\$ 50$ for single person; $\$ 100$ for family. & 90 percent of net wages. \\
\hline Nova Scotia & $\$ 50$ for single person; $\$ 100$ for family. & 100 percent. \\
\hline New Brunswick & $\begin{array}{l}\$ 150 \text { for single person; } \$ 200 \text { for family. If } \\
\text { a recipient is designated as having high } \\
\text { employment potential, the exemption is } \\
\text { increased for a single person by an } \\
\text { additional } \$ 250 \text {; for a family by } \$ 200 \text { for } \\
\text { two months and by } \$ 100 \text { for a third month. } \\
\text { Two-parent employable families are } \\
\text { eligible for the } \$ 200 \text { exemption for } 6 \\
\text { months with allowable extensions. }\end{array}$ & $\begin{array}{l}70 \text { percent of net eamed income for } \\
\text { singles and couples with children } \\
\text { for the first } 6 \text { months; then } 75 \\
\text { percent for the next } 6 \text { months; then } \\
100 \text { percent thereafter. } \\
65 \text { percent of net earned income for } \\
\text { families with children for the first } 6 \\
\text { months; then } 70 \text { percent for the } \\
\text { next six months; then } 100 \text { percent } \\
\text { thereafter. }\end{array}$ \\
\hline Quebec & $\begin{array}{l}\$ 174 \text { for single person; } \$ 60 \text { for single } \\
\text { parent; } \$ 225 \text { for two-parent family. }\end{array}$ & 100 percent. \\
\hline Ontario & $\begin{array}{l}\$ 143 \text { for single person; } \$ 275 \text { for single } \\
\text { parent with one child; and } \$ 346 \text { for couple } \\
\text { with two children. }\end{array}$ & 75 percent. \\
\hline Manitoba & $\begin{array}{l}\$ 100 \text { for each employable person in } \\
\text { household. }\end{array}$ & 75 percent of net earnings. \\
\hline Saskatchewan & $\begin{array}{l}\$ 100 \text { for single person; } \$ 175 \text { for a two- } \\
\text { person family considered non-disabled; } \\
\text { and } \$ 125 \text { for families with children. }\end{array}$ & $\begin{array}{l}100 \text { percent of net earnings for } \\
\text { single person and two person } \\
\text { family with no children; for } \\
\text { families with children, } \\
\text { Saskatchewan Employment } \\
\text { Supplement offers benefits equal to } \\
\text { a proportion of net earnings above } \\
\$ 125 \text {. }\end{array}$ \\
\hline Alberta & $\$ 115$. & 75 percent. \\
\hline British Columbia & $\begin{array}{l}25 \text { percent of any income earned after } \\
\text { recipient has been on welfare for three } \\
\text { months; the exemption is available only } 12 \\
\text { months during a } 36 \text {-month period, and the } \\
12 \text { months need not be consecutive. }\end{array}$ & $\begin{array}{l}75 \text { percent for twelve months } \\
\text { during a } 36-\text { month period; } \\
\text { thereafter } 100 \text { percent. }\end{array}$ \\
\hline
\end{tabular}

Sources: National Council of Welfare (1997b); and various provincial ministries responsible for social assistance. 


\section{FIGURE 1}

CANADA

SHARE OF POPULATION ON SOCIAL ASSISTANCE, BY PROVINCE, 1980-97 1/2/

(in percent of population)
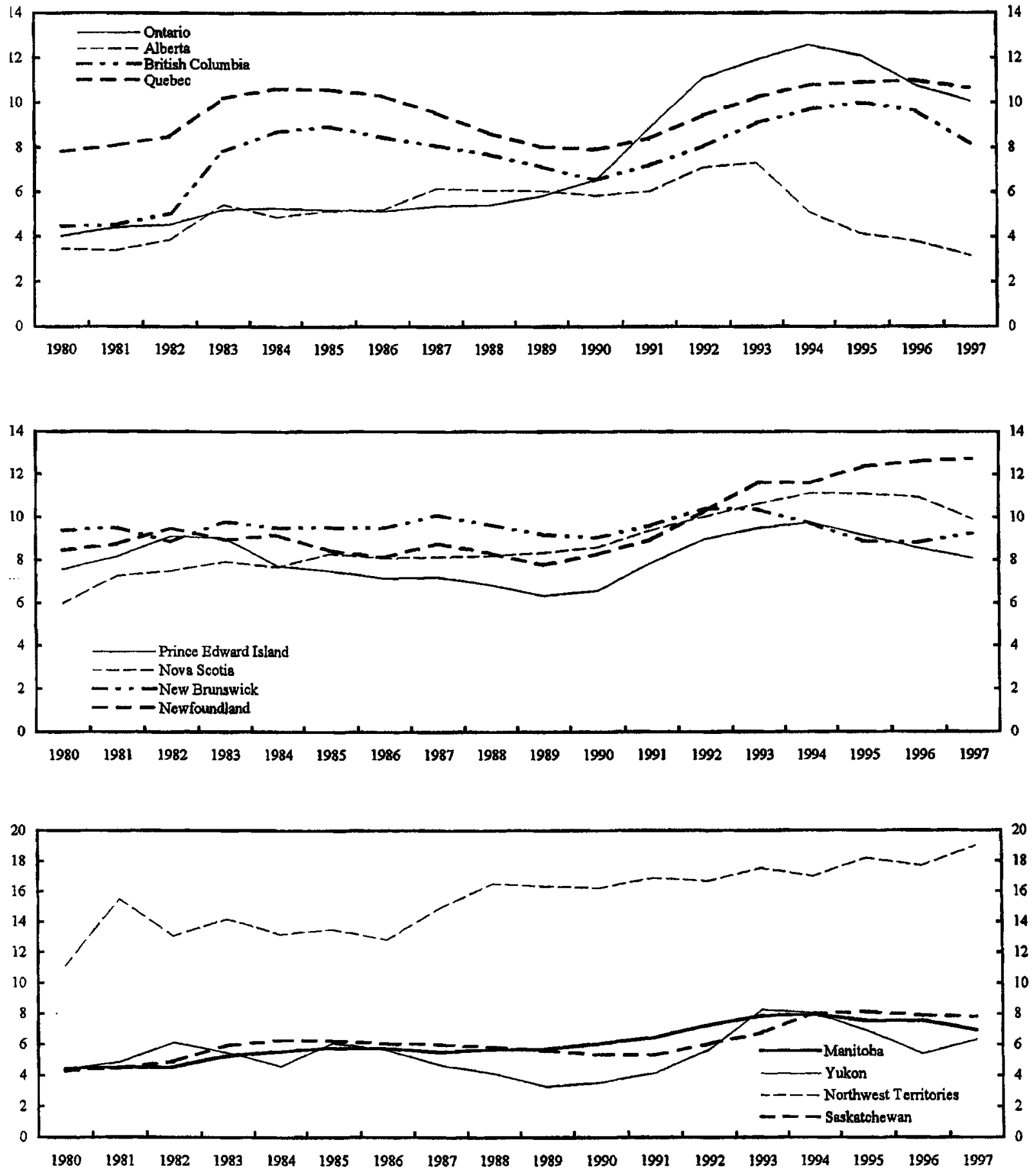

Sources: Human Resource Development Canada; and Fund staff estimates.

1/ Including dependents.

2/ Fiscal year ending in March. 
FIGURE 2

CANADA

REAL PER CAPITA EXPENDITURES ON SOCIAL ASSISTANCE, BY PROVINCE, 1980-97 1/

(in 1997 dollars) $2 /$
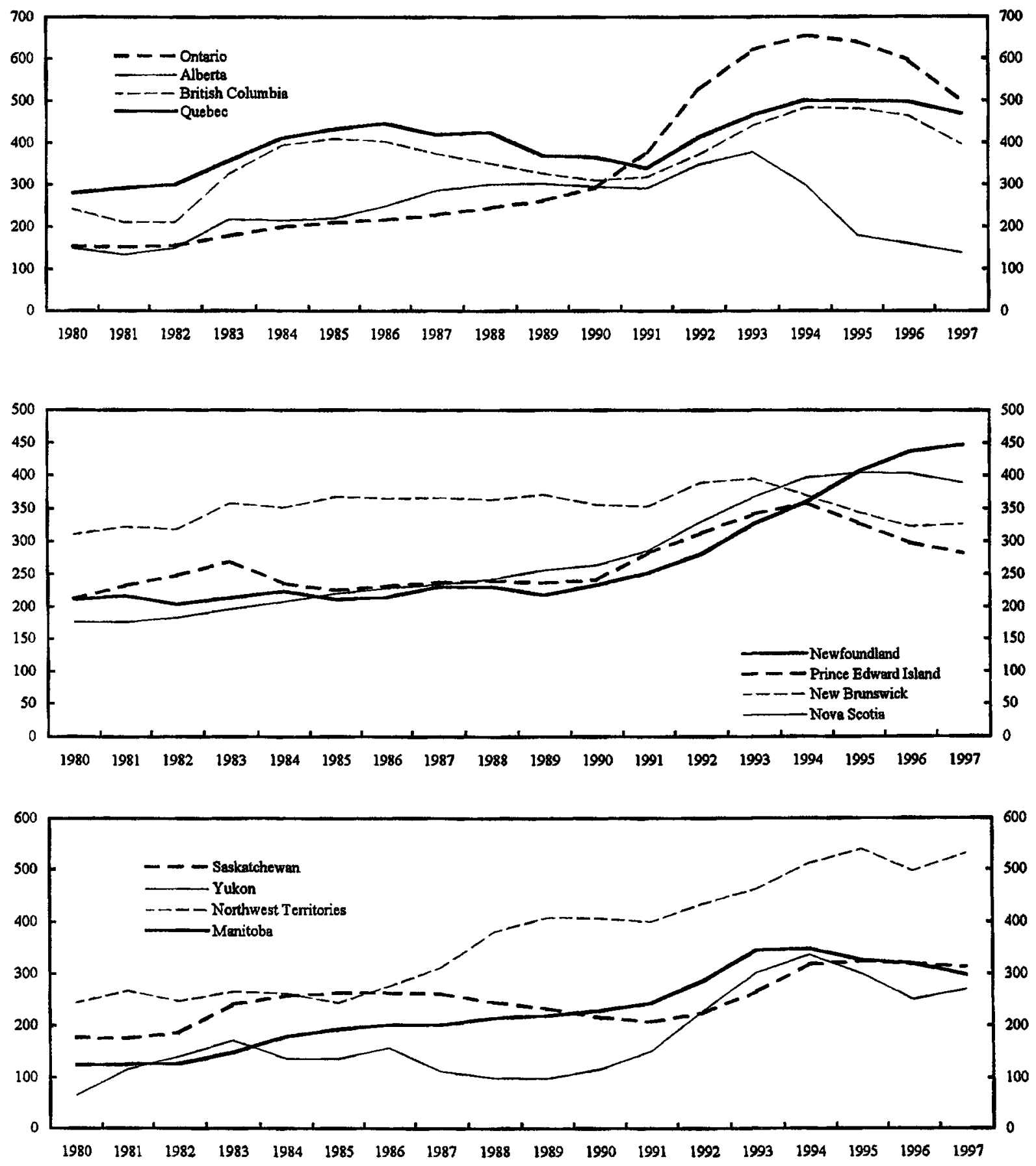

Sources: Human Resources Development Canada; and Fund staff estimates.

1/ Fiscal year ending in March.

2/ Deflated using consumer price index. 
CANADA

REAL PER CAPITA SOCIAL ASSISTANCE BENEFITS AND REAL PER CAPITA PERSONAL INCOME, 1971-97 (Index 1971=100)

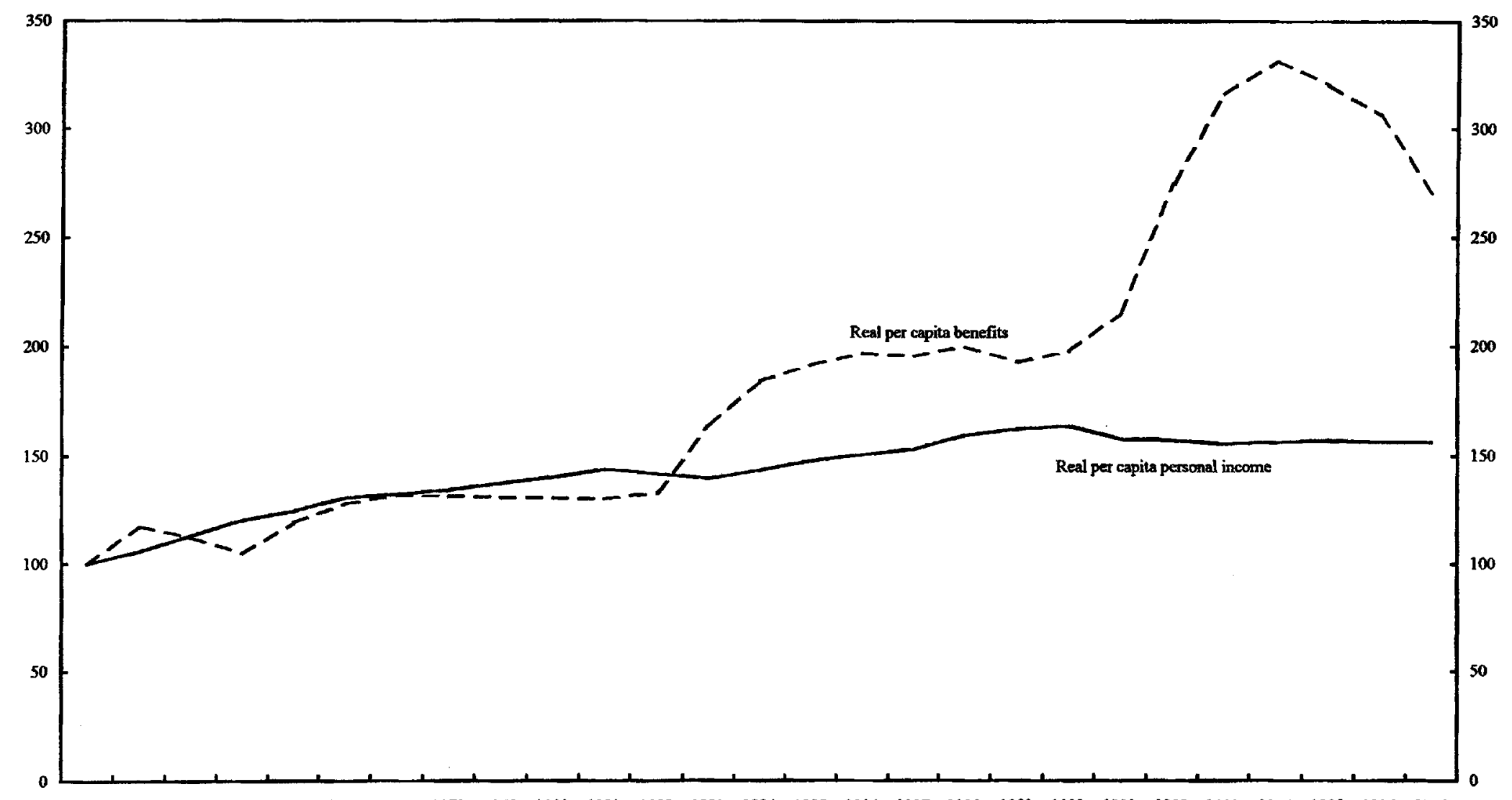

Sources: Statistics Canada. 


\section{CANADA}

REAL SOCIAL ASSISTANCE BENEFITS PER RECIPIENT, 1971-97

(In 1997 dollars per year)

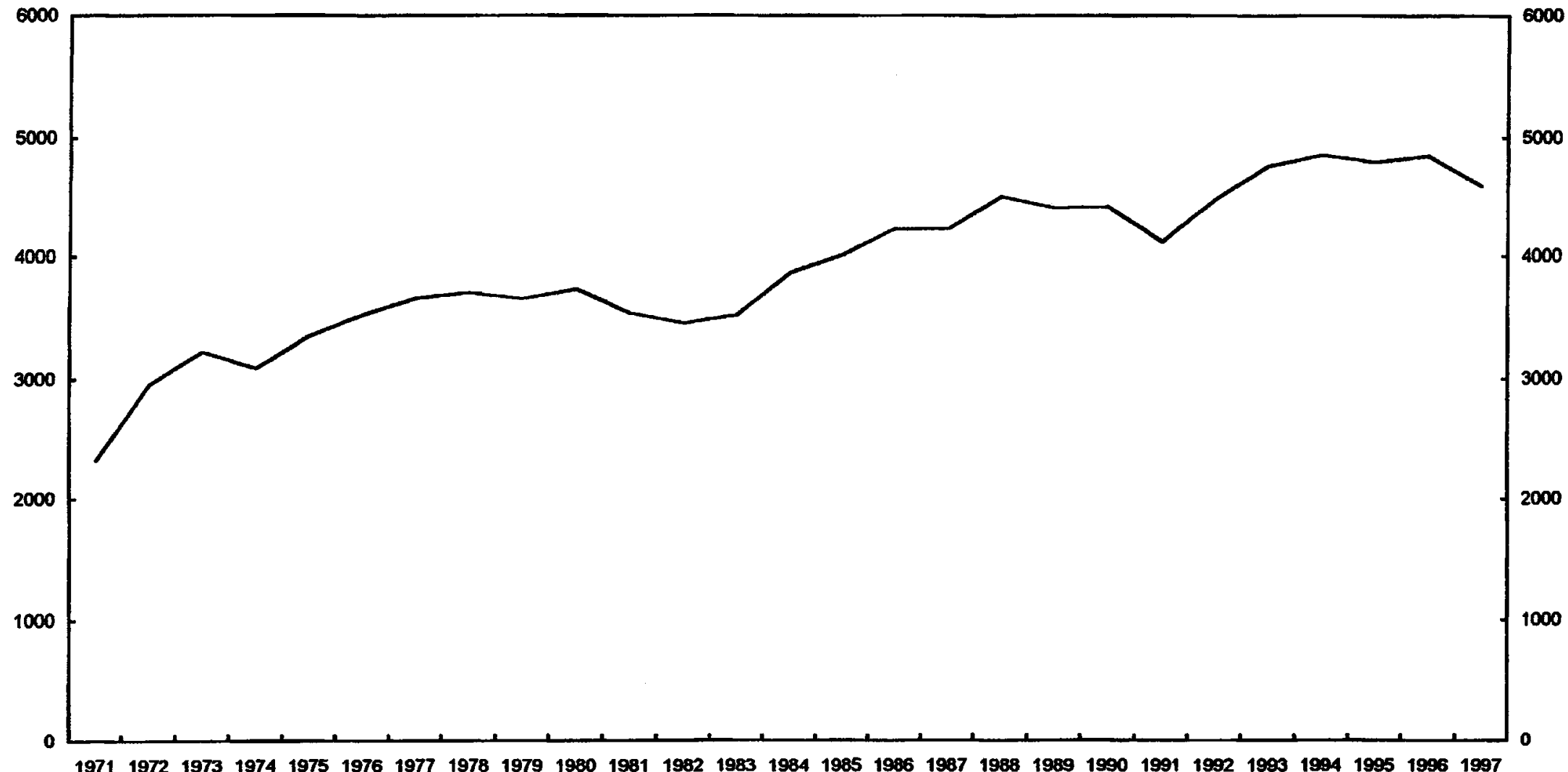

Sources: Statscan; and Fund staff estimates. 


\section{CANADA'S FINANCIAL SYSTEM ${ }^{1}$}

1. In January 1998, the Royal Bank of Canada and the Bank of Montreal announced their intention to merge. This was followed by a similar announcement by the Canadian Imperial Bank of Commerce and the Toronto-Dominion Bank in April 1998. Coming on the heels of the examination of financial services by the Task Force on the Future of the Canadian Financial Services Sector, these proposals prompted considerable debate and deliberation, culminating in the Minister of Finance's decision in December 1998 not to allow the proposed mergers. This paper discusses the structure of the Canadian financial sector, the forces leading to the proposed bank mergers, and the potential implications of increased concentration in the banking sector in Canada. It also reviews the main recommendations by the Task Force on the Future of the Financial Services Sector in the area of enhancing financial sector competitiveness.

\section{A. Structure of the Financial Sector}

2. Historically, the Canadian financial system was based on five principal groups: chartered banks, trust and loan companies, the co-operative credit movement, insurance companies, and securities dealers. The functions of the different kinds of institutions were separated. Chartered banks are incorporated and supervised by the federal government and have been traditionally involved in personal, residential mortgage, and commercial lending. Trust and loan institutions tended to specialize in residential mortgage lending and in term deposits, and they were the only institutions permitted to offer fiduciary services. They can be either federally or provincially incorporated and supervised. The co-operative credit movement (credit unions and caisses populaires) operates almost entirely under provincial jurisdiction. Traditionally, these institutions invested in residential mortgages and personal loans. The majority of insurance companies are federally supervised, but some companies are provincially regulated. The securities dealers have traditionally operated under the supervision of the provincial governments. They have typically engaged in activities associated with the underwriting and selling of bond and stock issues, offering investment advice and trading of securities in the secondary markets.

3. The period since the late 1980s has seen sweeping change in the structure of the financial sector. These changes have been largely the result of legislative actions that have blurred the lines of separation between the different kinds of institutions. Particularly noteworthy are the legislative amendments introduced in 1987 that allowed links between banks and securities dealers. The large chartered banks responded by entering the securities business either by buying existing securities dealers, as most did, or by establishing new

\footnotetext{
${ }^{1}$ Prepared by Brenda González-Hermosillo.
} 
dealers. As a result, the largest securities dealers are now all part of broader financial services groups headed by banks. ${ }^{2}$

4. Legislation in 1992 eliminated most of the remaining distinctions between the different financial institutions, allowing them to compete directly with one another by expanding their business powers and by permitting cross-ownership. All the major banks acquired a trust subsidiary, reflecting in part the financial difficulties encountered by trust companies in the early 1990 s. $^{3}$ In contrast, while some banks have made inroads into the provision of insurance services, this business is still dominated by the old-line insurance companies.

5. Table 1 provides an overview of the current structure of the Canadian financial sector. Chartered banks account for over 50 percent of the total assets of the Canadian financial sector. ${ }^{4}$ At the end of 1997, 11 Canadian-owned chartered banks accounted for 93 percent of the total assets of the banking system, while 44 foreign-owned banks accounted for the remaining 7 percent (Table 2). ${ }^{5}$ The largest six domestic banks account for 92 percent of the total assets of the banking system.

6. The Canadian banking system is one of the most concentrated in the industrial world (Figure 1). Although nonbank deposit-taking institutions (e.g., trust companies, caisses populaires, and credit unions) are significant players in the market for deposits, the largest six domestic banks account for about 70 percent of the total deposits held by all deposit-taking

\footnotetext{
${ }^{2}$ For example, in the government securities market before the 1987 legislative changes, domestic banks had about 15 percent of treasury bill auction winnings and 19 percent of Canada bond auction winnings. In 1996, the comparable numbers for banks and their securities dealer subsidiaries combined were 62 percent and 50 percent, respectively. Banks and their subsidiaries also accounted for 82 percent of the turnover in the secondary market for treasury bills and for 59 percent of the turnover in the secondary market for bonds in 1996 (Freedman (1998)).

${ }^{3}$ With their entry into the trust business, banks became important players in the market for assets under administration, with the six largest domestic banks representing about 80 percent of the total for this market (Freedman (1998)).
}

${ }^{4}$ Chartered banks are either classified as Schedule I or II. Schedule I banks are domestically owned and are widely held. The widely held rule stipulates that no individual or individual group can own or control more than 10 percent of the bank's equity. Foreign banks are Schedule II banks and are considered to be narrowly held even if they are widely held in their own jurisdiction.

${ }^{5}$ The number of foreign banks in Canada has declined in recent years from a peak of 59 in 1987. 
institutions (Figure 2). Foreign banks are small players in the retail deposit market. ${ }^{6}$ While Canadians have increasingly placed their savings in mutual funds instead of conventional deposits (Table 3), banks have recently entered into the mutual fund market in a significant way by offering a wide variety of bank-sponsored funds in their branches. Overall, the banks' share of the mutual funds industry is around 25 percent. $^{\text {. }}$

7. The six largest Canadian banks also play a predominant role in the markets for consumer credit, residential mortgage credit, and the financing of small and medium-size corporations (Figures 3, 4, and 5). Larger Canadian corporate customers have increasingly tapped capital markets directly for their funding needs, moving away from borrowing from banks. After reaching a peak of over 50 percent in the early 1980s, the portion of business funding derived from bank loans has since declined to around 30 percent (Figure 6). The role of foreign banks in these various markets has been quite limited, accounting for about 7 percent of credit to large businesses and about 2 percent of credit extended to small and medium-sized businesses. ${ }^{8}$

8. Despite its current high degree of concentration, the Canadian financial market seems to function competitively. ${ }^{9}$ The moderate decline observed in recent years in the interest spreads charged by the six largest domestic banks suggests that concentration has not led to uncompetitive behavior by domestic banks (Figure 7).

\section{B. Potential Implications of Bank Mergers}

9. After reviewing reports from the Competition Bureau with respect to competition concerns, from the Office of the Superintendent of Financial Institutions with respect to prudential issues, and from several parliamentary committees, the Minister of Finance announced on December 14, 1998 that the proposed bank mergers would not be considered until new legislation is in place to enhance competition in the sector and increase consumer

\section{${ }^{6}$ One notable exception is the Bank of Hong Kong.}

${ }^{7}$ The banks' share of the mutual funds market varies among the different segments of that market. The banks' highest market shares are in money market and mortgage mutual funds, where they accounted for 68 percent and 56 percent of the market, respectively, at the end of 1996 (Freedman (1998)).

${ }^{8}$ Task Force on the Future of the Canadian Financial Services Sector (1998).

${ }^{9}$ Competition is not precluded in highly concentrated markets if they are contestable. Markets are said to be "contestable" if potential competitors have unrestricted access to the market. The notion of "contestable markets" was first explored in Baumol (1982) and studies applied to the Canadian financial sector include Nathan and Neave (1989) and Shaffer (1993). 
protection. The Minister was of the view that the proposed mergers would lead to an unacceptable concentration of economic power in the hands of fewer, very large banks; a significant reduction of competition; and reduced policy flexibility of the regulatory authorities to address potential future prudential concerns arising from having fewer, very large banks. The Minister emphasized that priority would be given to establishing an appropriate policy framework for the financial sector and that, for that purpose, he would review the recommendations set forth by the Task Force on the Future of the Canadian Financial Services Sector (discussed below) and by parliamentary reports. The objectives of the policy framework will include putting in place a new review process to assess major bank merger proposals, promote competition by allowing the entry of new players (foreign and domestic), enable the financial sector to be at the leading edge of technological innovation, allow for strong Canadian institutions with a solid international presence, and protect consumers. The government would not consider any merger among major banks until the new policy framework is in place. Even then, new merger proposals will need to demonstrate, in light of the circumstances of the day, that they do not unduly concentrate economic power, significantly reduce competition, or restrict the government's flexibility to address prudential concerns.

10. The proposed mergers between the Royal Bank and the Bank of Montreal and the Canadian Imperial Bank of Commerce and the Toronto-Dominion Bank would have further increased concentration in the Canadian financial sector. Post-merger, Canada would effectively have had two mega-banks, one relatively large domestic bank, a few other smaller domestic banks, and several small foreign banks. Even when measured against the full financial industry in which other nonbank financial institutions compete in providing some of the same financial services, the two resulting mega-banks would have constituted a significant force in the overall financial market. The two new mega-banks would have accounted for more than 50 percent of total consumer credit (see Figure 3 ) and over 40 percent of total residential mortgage credits (see Figure 4) extended in the overall financial sector. The two newly formed banks would have accounted for more than 70 percent of the total assets, loans, and deposits in the banking system.

11. The case for bank mergers is based on the assumption that financial institutions need to be large and diverse to prosper in financial markets that are becoming increasingly globalized. This view rests on the assessment that, given technological requirements, it would be extremely expensive to maintain a competitive infrastructure for delivering financial services efficiently unless an institution is sufficiently large to manage these costs. In particular, economies of scale could be realized only by large financial firms. In addition, a successful financial institution would have to be large enough to take advantage of economies of scope, which may arise when it is more cost effective to produce two or more products jointly in a single production unit than to produce the products in separate specializing firms. Scope economies can arise from the spread of fixed costs over an expanded product base, or 
from cost complementarities in producing the different products. ${ }^{10}$ In international markets, it is also often asserted that it is essential for banks to be large to compete outside the domestic market. $^{11}$

12. Most of the studies on economies of scale and economies of scope are based on the experience of U.S. banks. ${ }^{12}$ This literature has provided little evidence that a bank needs to be a mega-institution to exploit economies of scale. In particular, several studies suggest that only small banks have the potential for scale efficiency gains and that the measured economies are usually relatively small. ${ }^{13}$ The fact that the U.S. financial system is much less concentrated than in Canada, and that the proposed mergers were between relatively large Canadian banks, would suggest that there was less likely to be substantial scale economies arising from the proposed mergers.

13. The computation of scope economies is based on comparing the predicted costs of producing a given bundle of financial products by two or more specialized firms with the costs of joint production by a single firm. Because of estimation problems and data availability, it is difficult to draw firm conclusions regarding the existence of scope economies and their potential magnitude. Studies on U.S. banks suggest that the synergies of producing joint products in banking may not be large; however, significant gains are possible in some cases. ${ }^{14}$

\footnotetext{
${ }^{10}$ Freedman and Goodlet (1998) discuss some of these propositions, noting that they are plausible on the surface but that they can be challenged to some degree. In particular, they stress that investment in expensive new technologies could be developed jointly, in the absence of mergers, through special arrangements among financial services providers.
}

${ }^{11}$ Mergers can also potentially reduce costs through managerial efficiency which results when an efficient bank with superior management talent acquires a relatively inefficient bank. Such efficiency gains result from adopting "best practices" where cost is minimized for a given output bundle. For U.S. banks, studies suggest that some banks have costs that can be as much as $\mathbf{2 5}$ percent above those of the best-practice banks and, hence, these managerial efficiencies can be significant (see, for example, Berger, Hunter, and Timme (1993)).

${ }^{12}$ Berger and Humphrey (1994) and Clark (1988) provide comprehensive surveys of this literature.

${ }^{13}$ See, for example, Mester (1987), Berger, Hunter, and Timme (1993), Berger, Hanckock, and Humphrey (1993), and Pulley, Berger, and Humphrey (1993).

${ }^{14}$ For example, Pulley and Humphrey (1993) found that large U.S. banks did not experience significant cost complementarities between deposit and loan products but did enjoy relatively small benefits of sharing fixed costs between these products. Using the profit function to evaluate optimal scope economies, Berger, Hancock, and Humphrey (1993) find that joint 


\section{Task Force on the Future of the Canadian Financial Services Sector}

14. In 1996, a Task Force on the Future of the Canadian Financial Services Sector was established, and the Task Force report was released in September 1998. Table 4 summarizes the report's main recommendations with regard to enhancing competition in the financial sector. ${ }^{15}$

15. The Task Force views the establishment and growth of new financial institutions as a critical element in enhancing competition. In particular, it recommends that the criteria for incorporation of financial institutions should be revised to facilitate that process. For example, foreign banks should be able to carry on any banking business in Canada, other than receiving retail deposits (i.e., of less than $\$ 150,000$ ), through branches of the foreign parent bank. Foreign banks that wish to take retail deposits in Canada would continue to be required to establish subsidiaries. The Task Force also recommends avenues to expand the powers of all financial institutions, including by extending access to the payments system to nonbanks, by allowing the retail sale of insurance in bank branches and by permitting banks and insurance companies to lease light vehicles.

16. With regard to ownership rules, the Task Force recommends that the widely held ownership policy should remain applicable to the largest financial institutions, permitting in some cases ownership positions in excess of 10 percent and up to 20 percent of equity. Smaller institutions, however, would be subject to a more flexible ownership rule to encourage entry and competition. With regard to the foreign acquisition of widely held large Canadian banks, the report proposes that in "exceptional" cases the Government should have discretion to approve such acquisitions, free from the impact of the widely held rules. ${ }^{16}$

17. The Task Force provides no direct recommendation regarding domestic bank mergers and acquisitions of large Canadian banks, other than to suggest the process and criteria that should be used to assess the mergers. However, it proposes that there should not be a general policy that would prevent large institutions from entering into business combinations with

\footnotetext{
${ }^{14}$ (...continued)
}

production is optimal for most U.S. banks, but that specialization is optimal for others.

${ }^{15}$ Other areas of recommendations made by the Task Force include: (i) empowering consumers (e.g., through ensuring increased disclosure and transparency of services, privacy, elimination of tied selling of products, access to basic banking services, availability of microcredit, and financing of aboriginal business); and (ii) improving the regulatory framework (e.g., by reducing the regulatory overlap between different levels of government or agencies).

\footnotetext{
${ }^{16}$ Such transactions would be subject to a similar process for domestic bank merger approvals. The buyer should be a widely held, regulated financial institution and the acquisition should be deemed to be in the interest of the Canadian public.
} 
other large institutions whether by amalgamation, acquisition, or other means. Mergers of large financial institutions could be permitted as long as the Minister of Finance is of the opinion that markets will remain competitive, that there are no material safety and soundness concerns, and that the transaction is in the public interest. The relevant public interest considerations would include: the cost and benefits to individual customers and small and medium-sized business; regional impacts; international competitiveness; employment; the adoption of innovative technologies; and the extent to which the approval may create a precedent.

18. The recommendations of the Task Force, as well as suggestions made by other interested groups on the future of the financial services sector, will be reviewed by the Minister of Finance before new financial sector legislation is introduced. 


\section{List of References}

Bank of Montreal, 1998, Information on Merger Issues, Toronto, Canada, September.

Baumol, W. J., 1982, "An Uprising in the Theory of Industry Structure," American Economic Review, March.

Berger, A. N., D. Hancock, and D.B. Humphrey, 1993, "Bank Efficiency Derived from the Profit Function," Journal of Banking and Finance, April.

Berger, A. N., and D. B. Humphrey, 1994, "Bank Scale Economies, Mergers, Concentration, and Efficiency: The U.S. Experience," Finance and Economics Discussion Series, 94-23, Federal Reserve Board, Washington D.C., August.

Berger, A. N., W. C. Hunter, and S.G. Timme, 1993, "The Efficiency of Financial Institutions: A Review and Preview of Research Past, Present, and Future," Journal of Banking and Finance, April.

Booth, Laurence, 1996, "Competition and Profitability in the Financial Services Industry," in Putting Consumers First: Reforming the Canadian Financial Services Industry, edited by Jack Mintz and James Pesando, C.D. Howe Institute, Policy Study 27, Toronto, Canada.

Clark, J., 1988, "Economies of Scale and Scope at Depository Financial Institutions: A Review of the Literature," Federal Reserve Bank of Kansas City Economic Review, 73, September/October.

Freedman, Charles, 1998, The Canadian Banking System, Bank of Canada Technical Report, March.

Freedman, Charles, and Clyde Goodlet, 1998, The Financial Services Sector: Past Changes and Future Prospects, Bank of Canada Technical Report, March.

Mathewson, Frank, and Neil Quigley, 1998, "Canadian Bank Mergers: Efficiency and Consumer Gain versus Market Power," C.D. Howe Institute, June.

Mester, L. J., 1987, “A Multiproduct Cost Study of Savings and Loans," Journal of Finance.

Nathan, A., and E. Neave, 1989, "Competition and Contestability in Canada's Financial System: Empirical Results," Canadian Journal of Economics, August.

National Caucus Task Force, 1998, A Balance of Interests, November. 
Pulley, L., A.N. Berger, and D. B. Humphrey, 1993, "The Other Side of the Coin: Bank Scope Economies from a Revenue Function,"Finance and Economics Discussion Series (FEDS), Board of Governors of the Federal Reserve System, August.

Pulley, L., and D.B. Humphrey, 1993, "The Role of Fixed Costs and Cost Complementarities in Determining Scope Economies and the Cost of Narrow Banking Proposals," Journal of Business, July.

Shaffer, S., 1993, "A Test of Competition in Canadian Banking," Journal of Money, Credit and Banking.

Task Force on the Future of the Canadian Financial Services Sector, 1998, Report of the Task Force, September. 
Table 1. Canada: Assets of Financial Institutions, 1997

\begin{tabular}{cr}
$\begin{array}{c}\text { In Billions } \\
\text { of Dollars }\end{array}$ & $\begin{array}{r}\text { Percentage } \\
\text { of Total }\end{array}$ \\
\hline
\end{tabular}

Chartered banks (Schedule I and II)

897.5

56.1

Trusts (excluding bank subsidiaries)

53.6

3.4

Credit unions and caisses populaires

107.0

6.7

Life insurers

178.3

11.2

Property and casualty insurers

53.6

Securities dealers (exluding bank subsidiaries)

28.7

Mutual funds

280.8

17.5

Total

$1,599.5$

100.0

Source: Statistics Canada, Cat. No. 61-008. 
Table 2. Canada: Bank Assets, 1997

(In millions of dollars)

\begin{tabular}{|c|c|c|c|c|}
\hline \multirow[b]{2}{*}{ Bank } & \multicolumn{2}{|c|}{ Total Assets } & \multicolumn{2}{|c|}{ Assets in Canada } \\
\hline & $\begin{array}{l}\text { Millions } \\
\text { of Dollars }\end{array}$ & $\begin{array}{l}\text { Percent } \\
\text { of Total }\end{array}$ & $\begin{array}{l}\text { Millions } \\
\text { of Dollars }\end{array}$ & $\begin{array}{l}\text { Percent } \\
\text { of Total }\end{array}$ \\
\hline Canadian banks & $1,229,901$ & 93.0 & 786,278 & 89.5 \\
\hline \multicolumn{5}{|l|}{ Of which: } \\
\hline Royal Bank of Canada & 262,865 & 19.9 & 188,737 & 21.5 \\
\hline Canadian Imperial Bank of Commerce & 277,677 & 21.0 & 156,610 & 17.8 \\
\hline Bank of Montreal & 227,752 & 17.2 & 126,630 & 14.4 \\
\hline Bank of Nova Scotia & 206,016 & 15.6 & 123,813 & 14.1 \\
\hline Toronto-Dominion Bank & 172,974 & 13.1 & 117,968 & 13.4 \\
\hline National Bank & 66,981 & 5.1 & 56,872 & 6.5 \\
\hline Laurentian Bank of Canada & 12,467 & 0.9 & 12,464 & 1.4 \\
\hline Canadian Western Bank & 2,007 & 0.2 & 2,022 & 0.2 \\
\hline Citizens Bank & 805 & 0.1 & 805 & 0.1 \\
\hline Manulife Bank of Canada & 346 & 0.0 & 346 & 0.0 \\
\hline First Nations Bank & 11 & 0.0 & 11 & 0.0 \\
\hline Foreign banks (44 banks in 1997) & 92,028 & 7.0 & 92,028 & 10.5 \\
\hline All banks & $1,321,929$ & & 878,306 & \\
\hline
\end{tabular}

Source: Task Force on the Future of the Canadian Financial Services Sector. 
Table 3. Canada: Personal Savings by Type of Institution

\begin{tabular}{|c|c|c|c|c|c|}
\hline & $\begin{array}{c}\text { Bank } \\
\text { Personal } \\
\text { Deposits }\end{array}$ & $\begin{array}{r}\text { Trust } \\
\text { Personal } \\
\text { Deposits }\end{array}$ & $\begin{array}{r}\text { Credit Union } \\
\text { and Caisses } \\
\text { Populaires } \\
\text { Deposits }\end{array}$ & $\begin{array}{l}\text { Mutual } \\
\text { Funds }\end{array}$ & Total \\
\hline \multicolumn{6}{|c|}{ (In millions of dollars) } \\
\hline 1991 & 216.5 & 114.7 & 68.4 & 49.4 & 449.0 \\
\hline 1992 & 228.7 & 113.3 & 73.7 & 67.3 & 483.0 \\
\hline 1993 & 263.8 & 79.5 & 78.0 & 114.6 & 535.9 \\
\hline 1994 & 278.9 & 68.7 & 81.9 & 127.3 & 556.8 \\
\hline 1995 & 295.9 & 64.4 & 87.2 & 146.2 & 593.7 \\
\hline 1996 & 292.4 & 62.9 & 90.8 & 211.8 & 657.9 \\
\hline 1997 & 289.9 & 48.1 & 90.9 & 283.2 & 712.1 \\
\hline \multicolumn{6}{|c|}{ (In percent of total personal savings) } \\
\hline 1991 & 48.2 & 25.5 & 15.2 & 11.0 & \\
\hline 1992 & 47.3 & 23.5 & 15.3 & 13.9 & \\
\hline 1993 & 49.2 & 14.8 & 14.6 & 21.4 & \\
\hline 1994 & 50.1 & 12.3 & 14.7 & 22.9 & \\
\hline 1995 & 49.8 & 10.8 & 14.7 & 24.6 & \\
\hline 1996 & 44.4 & 9.6 & 13.8 & 32.2 & \\
\hline 1997 & 40.7 & 6.8 & 12.8 & 39.8 & \\
\hline
\end{tabular}

Sources: Bank of Canada; and Task Force on the Future of the Canadian Financial Services Sector. 


\section{Table 4. Canada: Task Force on the Future of the Canadian Financial Services Sector Main Recommendations in Regard to Enhancing Competitiveness}

\begin{tabular}{|c|c|}
\hline $\begin{array}{l}\text { Facilitating new entrants } \\
\text { to the market }\end{array}$ & $\begin{array}{l}\text { The criteria and process of incorporation of financial institutions should be } \\
\text { revised to facilitate the establishment and growth of new financial institutions. } \\
\text { In particular, the Minister of Finance should have discretion to allow a new } \\
\text { financial institution, including a bank, to incorporate with less than the } \\
\$ 10 \text { million in capital currently required. } \\
\text { - Foreign banks should be able to carry on any banking business in Canada, other } \\
\text { than receiving retail deposits (i.e., of less than } \$ 150,000 \text { ), through branches of } \\
\text { the foreign parent bank. Foreign banks that wish to take retail deposits in } \\
\text { Canada will continue to require the establishment of subsidiaries of the foreign } \\
\text { parent bank to ensure adequate depositor protection. }\end{array}$ \\
\hline $\begin{array}{l}\text { Equity in consumer } \\
\text { insurance plans }\end{array}$ & $\begin{array}{l}\text { In order to promote more effective competition between banks and life insurance } \\
\text { companies (e.g., annuities have similar features to retirement savings instruments } \\
\text { offered by banks), there should be the same level of support to protect customers } \\
\text { of deposit-taking institutions and customers of life insurance companies. In } \\
\text { particular, the Task Force recommends that the insurance programs for federally } \\
\text { insured deposit-taking institutions and life insurers should be amalgamated. }\end{array}$ \\
\hline $\begin{array}{l}\text { Expanding business } \\
\text { powers: access to the } \\
\text { payments system }\end{array}$ & $\begin{array}{l}\text { The Canadian Payments Association Act should be amended to permit financial } \\
\text { institutions other than deposit-takers (e.g., life insurance companies, securities } \\
\text { dealers and money market mutual funds) to become members of the Canadian } \\
\text { payments system upon meeting criteria related to their solvency, liquidity, and } \\
\text { regulatory frameworks. }\end{array}$ \\
\hline $\begin{array}{l}\text { Expanding business } \\
\text { powers: access to other } \\
\text { networks }\end{array}$ & $\begin{array}{l}\text { The Minister of Finance should monitor operations of all networks (including } \\
\text { Interac) to ensure that they are operated in a manner designed to enhance } \\
\text { competition in financial services. }\end{array}$ \\
\hline $\begin{array}{l}\text { Expanding business } \\
\text { powers: retailing } \\
\text { insurance by deposit- } \\
\text { taking institutions and } \\
\text { light vehicle leasing }\end{array}$ & $\begin{array}{l}\text { Subject to the appropriate privacy and tied selling regimes, federally regulated } \\
\text { deposit-taking institutions should be permitted to retail insurance through their } \\
\text { branches. Similarly, federally regulated deposit-taking institutions and life } \\
\text { insurance companies should be permitted to lease light vehicles to consumers. }\end{array}$ \\
\hline $\begin{array}{l}\text { More flexible corporate } \\
\text { structures }\end{array}$ & $\begin{array}{l}\text { There should be no restrictions on corporate structures available to financial } \\
\text { institutions unless required by safety and soundness considerations. In particular, } \\
\text { federally regulated institutions should have the option of being organized as } \\
\text { subsidiaries of regulated financial holding companies under a new Financial } \\
\text { Holding Companies Act. }\end{array}$ \\
\hline
\end{tabular}




\section{Table 4. Canada: Task Force on the Future of the Canadian Financial Services Sector Main Recommendations in Regard to Enhancing Competitiveness (Concluded)}

\begin{tabular}{|c|c|}
\hline Ownership rules & $\begin{array}{l}\text { Large financial institutions (i.e., with shareholders' equity in excess of } \\
\$ 5 \text { billion), including banks, would continue to be subject to the } 10 \text { percent } \\
\text { widely held rule (i.e., no person or group of persons acting jointly or in concert } \\
\text { is allowed to own or control more than } 10 \text { percent of any class of shares) } \\
\text { without the approval of the Minister of Finance. However, the Minister of } \\
\text { Finance should have the discretion to permit ownership positions in excess of } \\
10 \text { percent and up to } 20 \text { percent for large financial institutions. Shareholders } \\
\text { permitted to own more than } 10 \text { percent should not collectively own or control } \\
\text { more than } 45 \text { percent of any class of shares. } \\
\text { - Financial institutions with more than } \$ 1 \text { billion but less than } \$ 5 \text { billion in } \\
\text { shareholders' equity would be required to have at least } 35 \text { percent of their } \\
\text { voting participating shares widely held and publicly traded. } \\
\text { - In order to foster start-ups and competition, financial institutions with less than } \\
\$ 1 \text { billion in equity would be able to be closely held, including ownership by } \\
\text { one person or company. } \\
\text { - The Government should have the power, to be used only in "exceptional" } \\
\text { cases, to approve the acquisition of a large widely held Canadian financial } \\
\text { institution by a foreign purchaser, free from the impact of the widely held rules. } \\
\text { Any such transaction should be subject to: the completion of the usual process } \\
\text { for merger approval (reviewed below); the buyer should be a widely-held, } \\
\text { regulated financial institution; and the acquisition should be deemed to be in the } \\
\text { interest of the Canadian public by increasing competition, or enhancing the } \\
\text { safety and soundness of the Canadian financial system. }\end{array}$ \\
\hline Consolidation and mergers & $\begin{array}{l}\text { The Task Force provides no direct recommendation regarding mergers and } \\
\text { acquisitions of large domestic banks. However, it proposes that there should } \\
\text { not be a general policy which prevents large institutions from entering into } \\
\text { business combinations with other large institutions whether by amalgamation, } \\
\text { acquisition or other means. The Task Force recommends that mergers should } \\
\text { be assessed by the Competition Bureau in respect of competition concerns, } \\
\text { OSFI in respect to prudential issues, and the Minister of Finance in respect of } \\
\text { general public interest considerations. Mergers of large financial institutions } \\
\text { should be permitted as long as the Minister is of the opinion that markets will } \\
\text { remain competitive, that there are no material safety and soundness concerns, } \\
\text { and that the transaction is in the public interest. } \\
\text { - In assessing whether approval for mergers should be given, the relevant public } \\
\text { interest considerations would include: the cost and benefits to individual } \\
\text { customers and small and medium-sized business; regional impacts; } \\
\text { international competitiveness; employment; the adoption of innovative } \\
\text { technologies; and the extent to which the approval may create a precedent. }\end{array}$ \\
\hline
\end{tabular}


FIGURE 1

CANADA

BANKING CONCENTRATION RATIOS

RELATIVE TO TOTAL BANKING SYSTEM ASSETS, 1997

(Percentage)

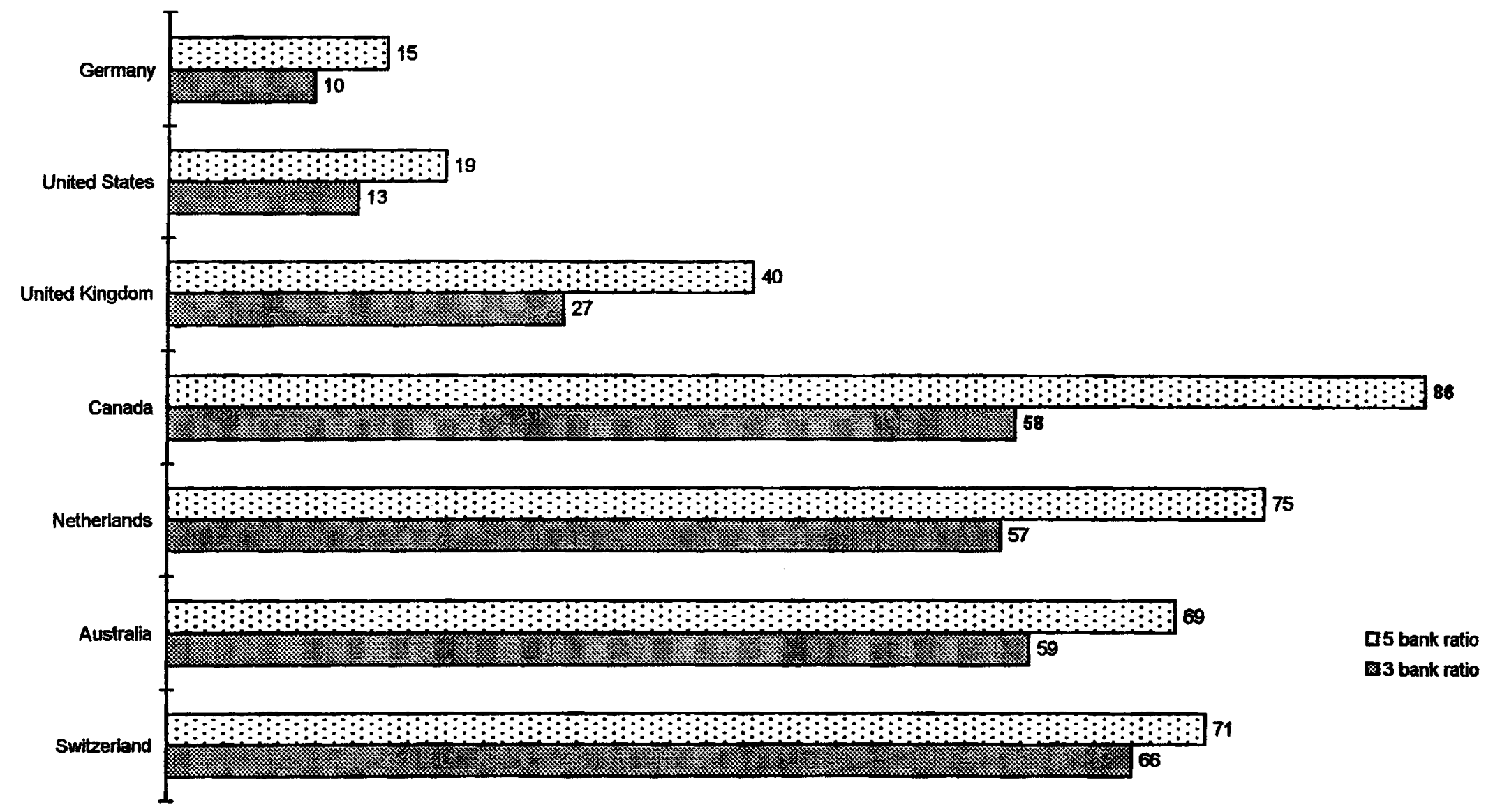

Source: Task Force on the Canadian Financial Services Sector. 
FIGURE 2

CANADA

DEPOSITS IN CANADA, 1997

$\$ 714$ billion

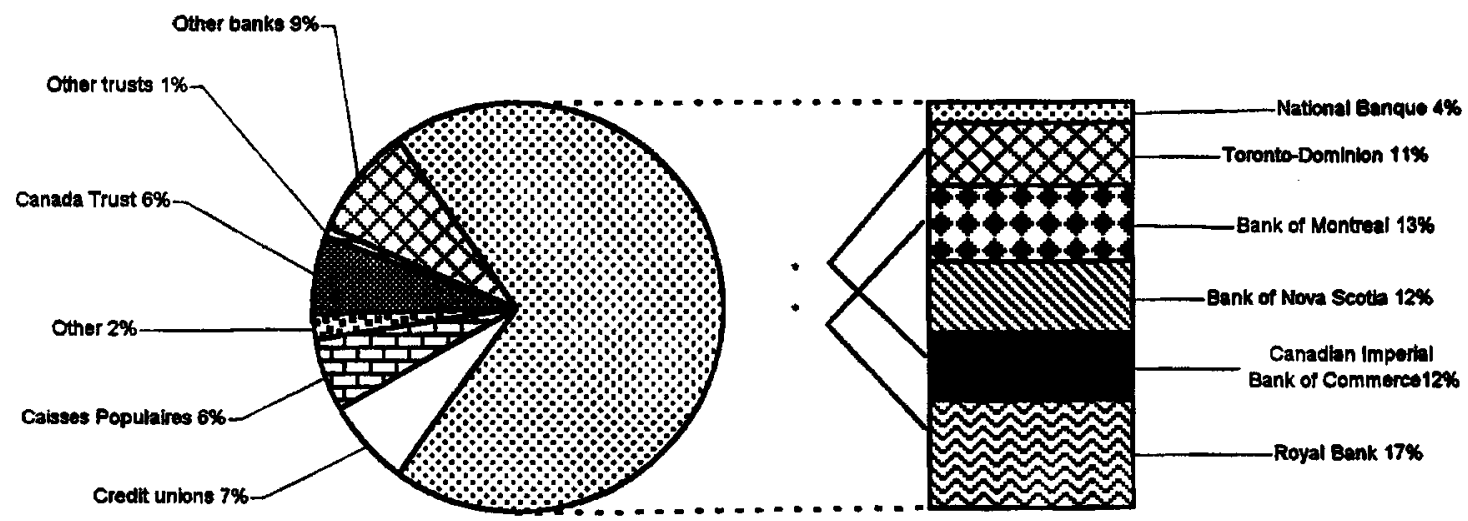

Source: Task Force on the Canadian Financlal Senices Sector.

- Proposed mergers

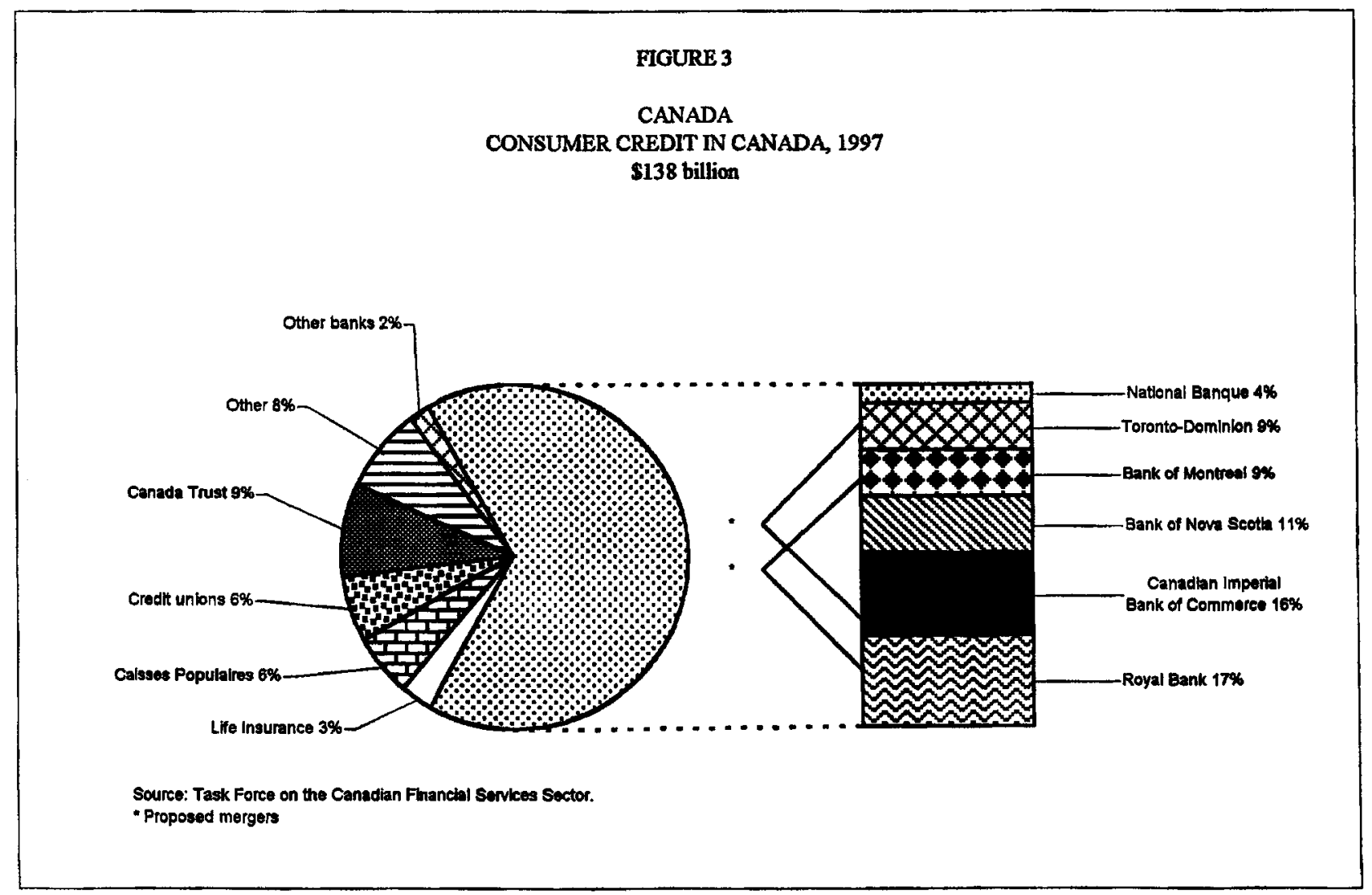

(C) International Monetary Fund. Not for Redistribution 


\section{FIGURE 4}

CANADA

RESIDENTIAL MORTGAGE CREDIT IN CANADA, 1997

$\$ 373$ billion

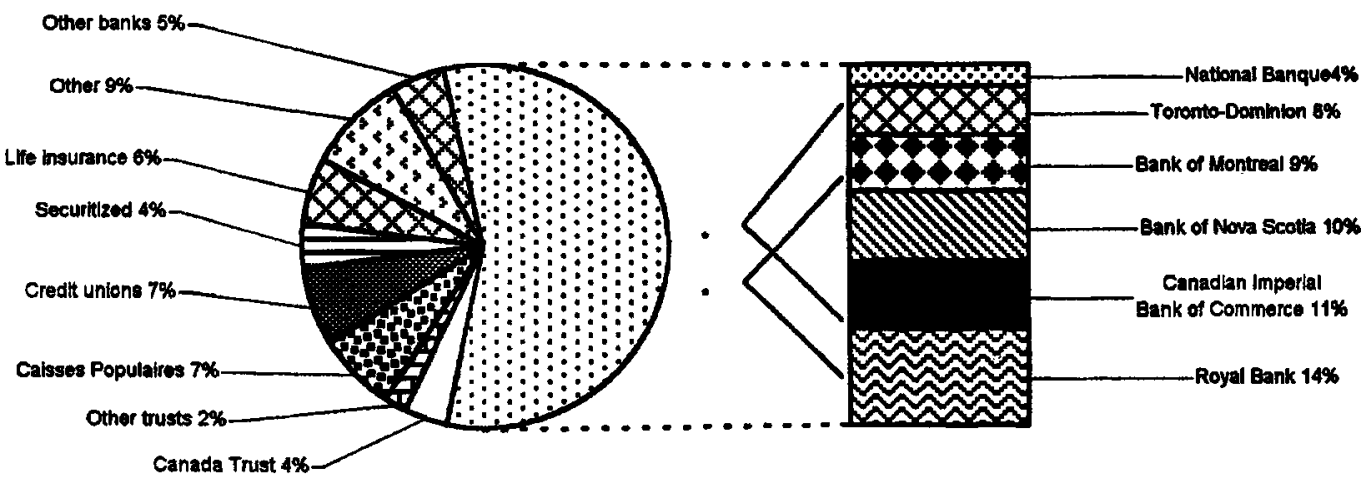

Source: Task Force on the Canadian Financlal Services Sector.

- Proposed mergers

\section{FIGURE 5}

CANADA

FINANCING OF SMALL AND MEDIUM SIZE CORPORATIONS IN CANADA, 1997

$\$ 110.9$ billion

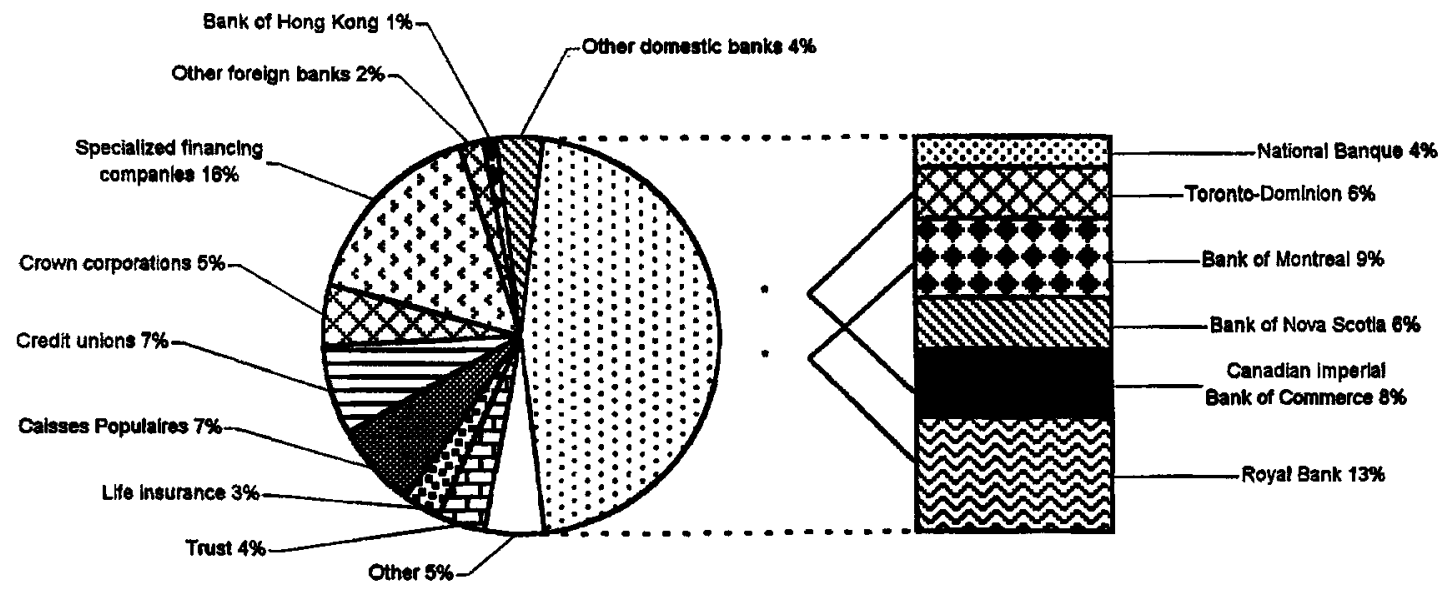

Source: Task Force on the Canadlan Financlal Servlces Sector.

- Proposed mergers 
FIGURE 6

CANADA

BANK SHARE OF BUSDNESS CREDIT MARKBT

(Percentage)

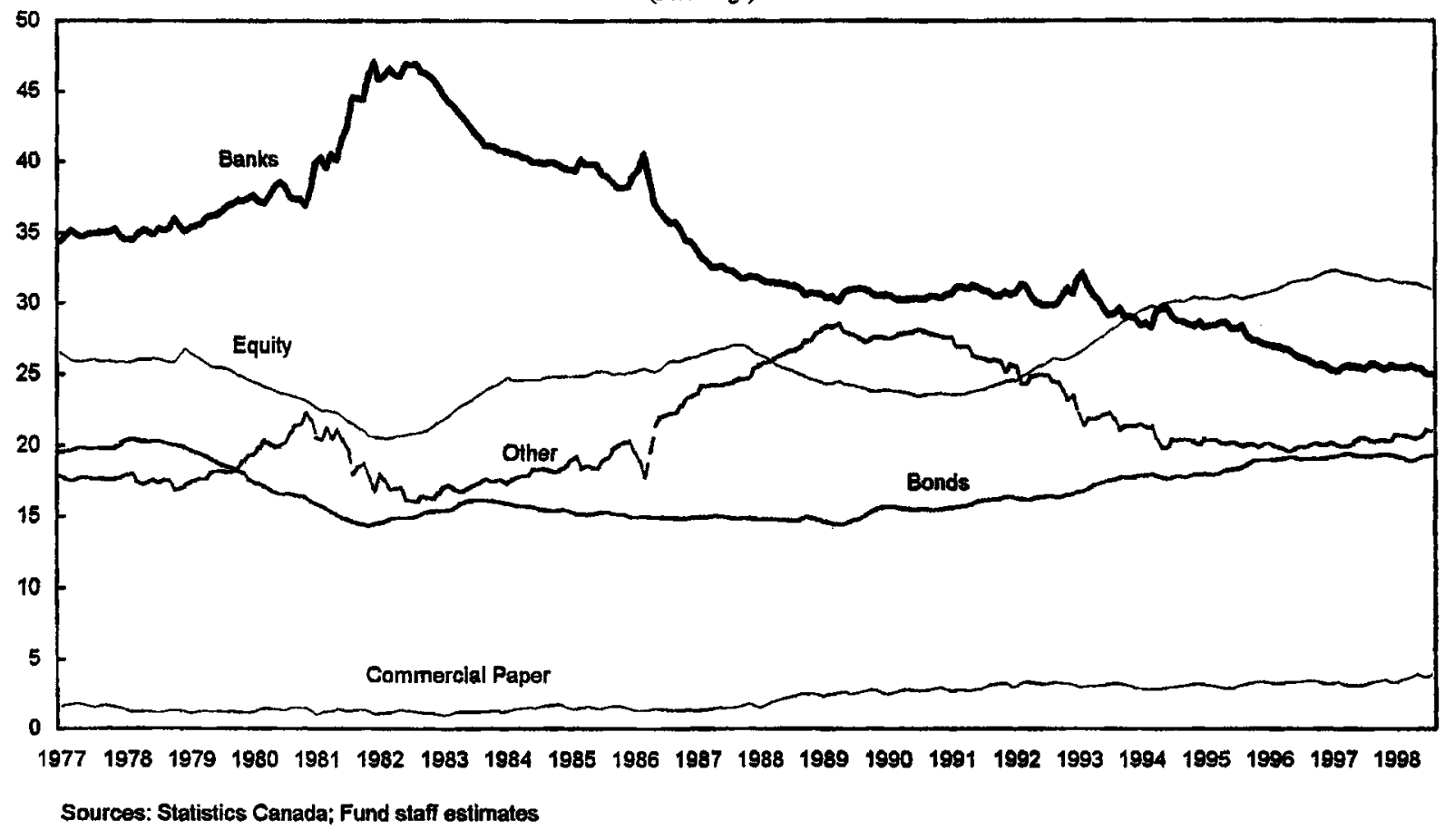

FIGURE ?

CANADA

INTRREST RATE SPRBADS OF SIXLARGEST BANKS

(Percentage of average assets)

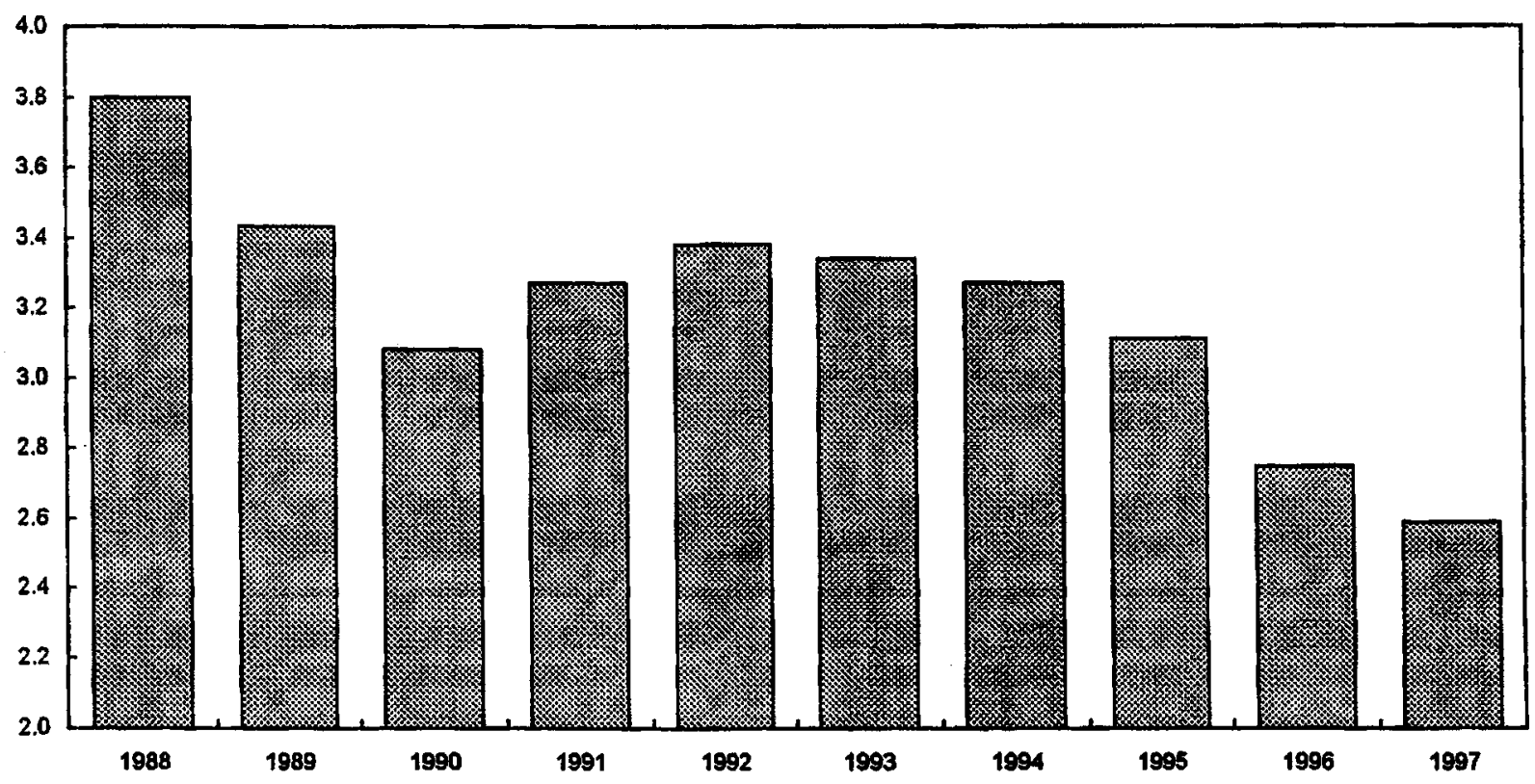

Source: Canadian Bankers Association. 
VIII. OFFICIAL DEVELOPMENT ASSISTANCE

1. Canada's official development assistance (ODA) to developing countries and multilateral institutions, measured on a Development Assistance Committee basis, totaled 0.36 percent of GNP in 1997 (US\$2.2 billion), compared with 0.32 percent in 1996 and 0.46 percent in 1992 (see tabulation below). The Government remains committed to reaching a target for ODA of 0.7 percent of GNP, as its fiscal situation allows, and consistent with its other priorities.

Canada: Official Development Assistance 1/

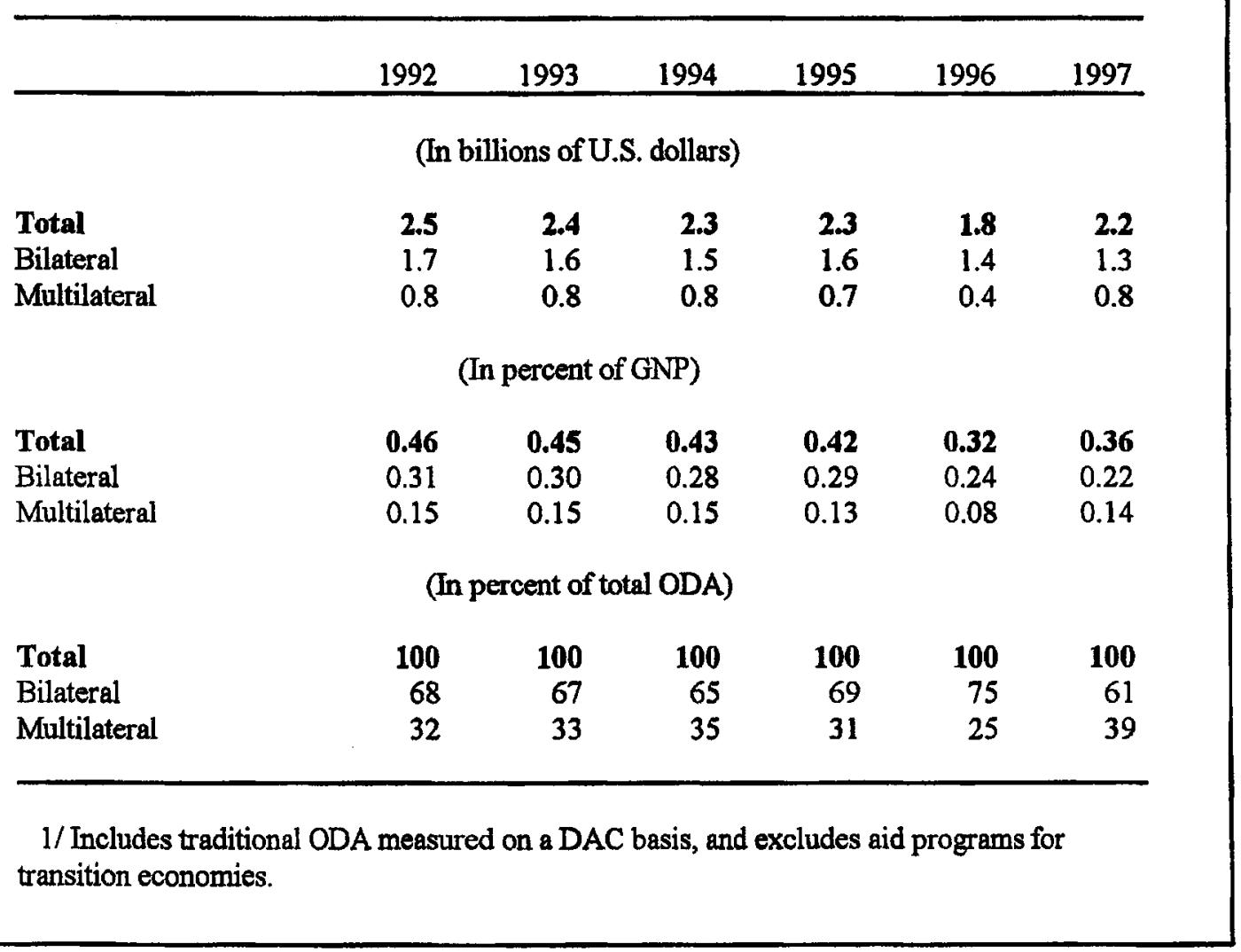

2. The overall objective of Canada's ODA is to support sustainable development in developing countries in order to reduce poverty and to contribute to a more secure, equitable, and prosperous world. To this end, Canada's ODA priorities are: (i) basic human needs; (ii) women in development; (iii) infrastructure services; (iv) human rights, democracy, and good governance; (v) private sector development; and (vi) the environment. Canada's ODA targets countries in Africa, Asia, and the Americas, and the majority of ODA is distributed to lowincome countries, particularly in Africa. Canada also provides support to countries in Central and Eastern Europe and the former Soviet Union. 